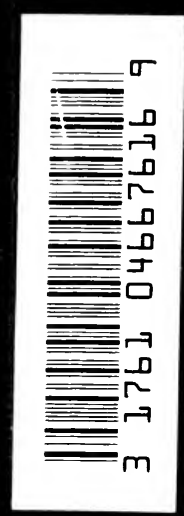


. 



$$
\cdot
$$




$$
\text { , }
$$


THE STATUS OF LABOR IN ANCIENT ISRAEL 


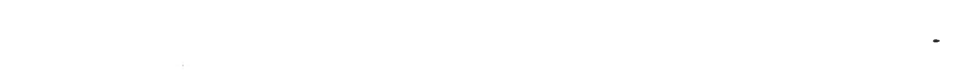




\section{THE STATUS OF LABOR IN ANCIENT ISRAEL}

MAYER SULZBERGER, LL.I.

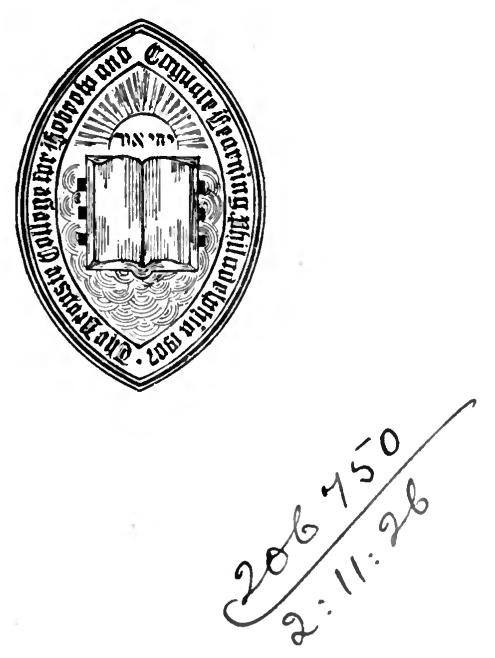

PHILADELPHIA

THE DROPSIE COLLEGE FOR HEBREW

AND COGNATE LEARNING 
Printed at THE CONAT PRESS, Philadelphia, Penna., U.S.A. 
TO THE

HONORABLE ROBERT VON MOSCHZISKER, CHIEF JUSTICE OF PENNSYLVANIA THIS LITTLE WORK IS DEDICATED IN TOKEN OF OUR ANCIENT AND AFFECTIONATE FRIENDSHIP. 


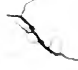




\section{THE STATUS OF LABOR IN ANCIENT ISRAEL*}

\section{PREFACE}

THE conclusions reached in the following four lectures will scarcely meet with ready acquiescence, since they depart from notions very generally entertained.

Their form too is not according to the conventional standard. There has been no attempt at dogmatism and no effort to achieve literary grace.

Their object was to attract the attention and arouse the efforts of the students of the "Dropsie College for Hebrew and Cognate Learning," to follow the author's procedure in investigating the subject without preconceived opinions, and to stimulate research in similar directions.

To accomplish this purpose, the author deemed it best to cite at length the data on which he worked and to show the process whereby he reached his conclusions.

Needless to say, the texts from which he worked, nowhere state, in so many words, the conclusions arrived at by him. Half a century's acquaintance with witnesses and their testimony has convinced him that no narrative, however sincere, ever tells the whole story. There appears to be a feature of the human mind which is averse to stating facts that are so familiar to the narrator, that he subconsciously assumes that everybody knows them as well as himself, and that to repeat them would be absurd. Hence the true meaning of a witness' narrative is to be found not only in what he expressly says, but also in what

*A course of four lectures read before the Dropsie College For Hebrew and Cognate Learning, January 14, 16, 23 and February 4, 1923. 
he does not say, but which may be fairly implied from the words used.

On this principle, the author has, on occasion, acted, and hence are derived some conclusions which may, at first sight, seem bizarre.

This method also involves the necessity, or at least the desirability, of setting out texts in full wherever they are made use of. It follows that some of them are stated more than once, and that ungainliness in the presentation results.

The desire to make the lectures educative is the only excuse for such defects.

The author hopes, however, that he has made at least a beginning toward a better comprehension of the labor question in ancient Israel.

THE reader of the English versions of the Hebrew Scriptures must have been struck by the frequency with which he finds "the stranger, the fatherless and the widow" mentioned together. The coupling of the rank outsider, with those who apparently belong to the most intimate circle of the insiders, arouses attention.

An easy explanation of the phenomenon is that these classes are dependent upon the gracious kindness of the community and that, in this respect, they stand on common ground. This answer leaves us uninformed.

Why should every stranger, every fatherless child, every widow be thrown on public charity?

No intelligent government would tolerate the influx of large masses of aliens who could do nothing for the community but would be a mere burden.

Moreover, most fatherless children and most widows would have family connections who would provide for them 
and many must have had shares in estates which precluded the necessity of public charity.

It is true that the common translation of these words, ger, yatom and almanah by stranger, fatherless and widow has much justification. Undoubtedly they all, on some occasions, have these meanings.

We must, however, keep in mind, that in the Hebrew as in all other languages, ancient and modern, there are many words which have more than one meaning and that these various meanings are sometimes conspicuously far apart and often seem unrelated to each other.

Take as an example, this very word stranger in our own language. Murray's Dictionary (volume 9, pp. 10791081) lists twenty-five meanings for it, covering as might be expected, a wide range of thought. That it stands for "one who belongs to another country", everybody knows, but that on certain occasions it means the British coin called "the guinea", few would guess, though, on reflection, many of us will realize that here at home, five-dollar gold pieces may fairly be called "strangers" by the most of us.

The moral is that times, circumstances, even caprices cause the attribution of new meanings to well-known words, and that such new meanings become at times general and at times merely narrow and technical.

If we then find that the general meanings of ger, yatom and almanah in the Biblical versions leave us puzzled in the endeavor to discover why this stranger should be thrust into the very heart of the national household, and why orphanage and widowhood should be constantly subject to attacks which must be fended off, it will be reasonable to seek for an explanation in any direction which may give us light.

Acting on this hint we may fairly inquire whether the 
words in question have not other meanings than those accepted by the versions.

As the word ger starts the puzzle, we may begin with it. That it means stranger by the rules of etymology is true. Etymology is, however, not the sole or final determining cause of all the meanings of words as historically developed.

There are other Hebrew words that are also translated "stranger": nokri (ben nekar), zar, toshab, sakir. An analysis of the passages in which these words are used, shows that at a stage of Hebrew history, as early at least as the reign of David, and probably earlier, the Hebrews had divided these foreigners into two great classes, the one characterized by unmitigated foreignness, while the foreignness of the other class was modified by closer social relations. The first class - the absolute foreigners - were the zar and the nokri. The second class-relative foreigners-were the ger, the toshab and the sakir.

It may be noted that in the progress of time, some of these words underwent startling changes of meaning.

Zar, for instance, from being practically synonymous with nokri, ${ }^{\mathrm{r}}$ came in time to include a non-member of any particular body, in which sense it is found applied even to Hebrews standing outside of an intimate circle. ${ }^{2}$

Nokri, is applied in general to the unmitigated, the hostile alien. But in his case there is one important exception, to wit, the nokri slave, the 'ebed.

While it is true that the word that interests us particularly is ger, it is necessary in order to understand it fully that we should comprehend what the nokri was and ascertain whether the ger was like him, or if he was not,

${ }^{1}$ Deut. 32.16; Isa. 1.7; 43.12; 61.5; Jer. 5.19; 51.2; Ezek. 11.9; 28.7, 10; 30.12; 31.12; Hosea 7.9; 8.7, 12; Psalm 44.21; 81.10; Job 19.15. 25.5 .

${ }^{2}$ Exod. 29.33; 30.33; Lev. 22.10, 12, 13; Num. $1.51 ; 3.10,38 ; 17.5 ; 18.4$, 7 ; Deut. 
we should determine in what respect they differed.

Initially, it is well to dispose of the slaves.

Among the ancient nations in general slavery was an important institution. It represented the great labor force. While the masters were continually ready for war or actually waging it, the slaves did the bulk of the peaceful work necessary for the community.

With the Hebrews it was otherwise.

Their position in Egypt was not such as enabled them to acquire or to hold others in slavery. When, soon after the Exodus, the invasion of Canaan was begun, the tribes Reuben and Gad (later joined by the half-tribe of Manasseh) elected to remain in the land East of Jordan and the Dead Sea, because they judged it to be a good place for cattle-raising. ${ }^{3}$ Being a pastoral people, by inheritance, the sight of the goodly land took away their ambition to become agriculturists in the Westland. Moses acquiesced in their decision, stipulating however that their soldiers should accompany the other tribes in the war against Canaan. They were to leave "their wives, their little ones and their cattle" in the land beyond Jordan to await the return of the menfolk from the war. If there had been any considerable number of slaves, there would, in that connection, have been some mention of them. At most there could have been but few and in this respect the other tribes were, without doubt, in like condition.

The slave was called 'ebed. If he was bought, this term was supplemented by the words miknat kesef (bought for money). If he was born of slave parentage in the household, he was called ben-bayit (son of the house), or yelid bayit (born in the house), or ben-amah (son of the handmaid), these three terms being nearly or quite synonymous.

Something, by the way, should be said concerning 'Num. 32.1-42. 
the mode in which these words have been rendered by the translators. They are all compound nouns, and should be so treated. The versions, however, analyze the expressions and translate the component elements separately. For instance, in Genesis 15.3 Abraham complains to God: "I am childless and my ben-bayit will be my heir." This, in effect, characterizes the relation as being a kind of qualified adoption. The versions render "one born in my house is to be mine heir," ignoring the fact that a man's own son is usually born in his house. The rendering should have been: "I am childless and my house-born slave will be my heir." The word is used in this sense in Ecclesiastes 2.7.

And so with yelid-bayit.

In Genesis 14.14 when Abraham enters into a campaign to release Lot who had been captured, he armed his trained home-born slaves (hanikaw yelide beto), pursued and defeated the ravishers. The versions again seem to miss the point, though A. V. senses it.

So too in the 17 th chapter of Genesis where the covenant of Abraham is established. The 12th and 13th verses are careful to enforce the obligation to perform the rite on slaves, whether miknat kesef or yelid bayit. The words are used in the same sense in Leviticus 22.11 and in Jeremiah 2.14 .

In considering the position of the slave we must always keep in mind that the Hebrews had a rooted aversion to the system. To them it seemed an institution "accursed"4 and this attitude made the lot of their slave essentially different from his condition among other nations and from forms of slavery persisting to our own time.

The conspicuous feature that contributed to his betterment was his admission to participation in the family worship. 
Tradition refers this custom to the most ancient times. The covenant of Abraham was to be entered into not only by every male of the immediate family, but the master's obligation was to enter every male slave. ${ }^{5}$

The female slave (the $a m a h$ ) was even in more intimate relationship. She was often the daughter of Hebrew parents. Occasionally the master bought her either to make her his own wife ${ }^{6}$ or the wife of his son. ${ }^{7}$ The position of the Hebrew slave was not one of misery or degradation. Eliezer, the 'ebed of Abraham, is called the ruler (moshel) of Abraham's possessions. ${ }^{8} \mathrm{He}$ it is who is entrusted by his master with the all-important mission of selecting and procuring a fitting wife for Isaac, and when he has found her, he presents her with rare jewels and raiment which he had brought.9 He is treated with the consideration of an equal not only by Abraham but by Laban.

Eliezer was one of Abraham's home-born slaves, a ben-bayit. ${ }^{\mathrm{x}}$

An example equally striking is found in 1 Chronicles $2.34,35$. Sheshan, a Judean magnate, gives his daughter in marriage to his Egyptian 'ebed Yarha. Of course, as an 'ebed, he had been naturalized, but he was an 'ebed none the less.

The Book of Proverbs (17.2) lays it down that a wise slave ('ebed maskil) shall not only be preferred to a profligate son (ben mebish), but shall take the latter's share in the father's estate with the upright brothers. These are not mere instances of individual kindliness. They are the expression of rooted national convictions.

Among the Hebrews the slave was not obliged to struggle for recognition as a human being. They held in abhorrence the views of other nations, like the Babylonian,

'Gen. 17.9, 11, 12, 13.

${ }^{8}$ Gen. 24.2.

${ }^{\circ}$ Gen. 24.53.

'Exod. 21.9.

${ }^{10}$ Gen. 15.3. 
as expressed or implied in the Hammurabi code, under which the slave was a mere chattel, whose owner could kill him without responsibility because he was merely destroying a piece of his property, the loss of which was his own and concerned no one else.

Far other views were reflected in the Hebrew laws.

Personal injuries to a slave were crimes punishable by the State. If a master maim his slave so that he or she loses a tooth or an eye, the slave goes free. ${ }^{\mathrm{Ir}}$

On the subject of the slave's status in the Hebrew household, it may not be amiss to quote a few passages from the admirable Hebräische Archäologie of Professor Benzinger. ${ }^{\mathrm{x} 2}$ The translation is ours:

"The slaves were also part of the family. In passing judgment on Israelitish slavery, one may not start with the prepossessions derived from contemplating modern slavery among Christian peoples. . . . There is practically not enough difference between the position of the slaves and that of the other members of the household to warrant us in expending compassion upon them as if they were miserable and unfortunate. . . . In the cultural state of the times, Hebrew slavery was a blessing for both master and servant."

"We learn that the slaves were uniformly treated as members of the family, for whose well-being the master cared as for that of his children. They were not mere dumb slaves, but were often asked for their opinion and advice (1 Sam. 9.6ff; 25.14ff)."

"As member of the family, the slave was admitted to the family worship, wherefore he had to be circumcised. Thereby, too, he became competent to carry on and to inherit the family worship. By reason of this religious

11Exod. 21.26, 27.

${ }^{12}$ Hebräische Archäologie von Dr. J. Benzinger (Freiburg i. B. und Leipzig, 1894) pp. 159-162. 
association, he received kindly and fatherly treatment just as do to-day the slaves in Islam. The 'brotherly feeling' among members of the religion has never been whittled down to a mere phrase, as in the Christian world, but is a very real power." Thus far Benzinger.

This favorable view of the condition of the Hebrew slave is, however, not universal. The dissenting opinion seems to be based on one striking text, which has in it a phrase singularly like the Babylonian principle. It is Exodus 21.20, 21 and reads: "If a man smite his bondman ('ebed) or his bondwoman (amah) with a rod and he die under his hand, he shall surely be punished (nakom yinnakem). Notwithstanding, if he continue a day or two, he shall not be punished (lo yukkam); FOR HE Is HIS MONEY."

From this last phrase, some have drawn the conclusion that a slave was looked upon as a mere piece of property and not as a fellow-being. Such a view totally ignores the legal provisions above cited and counts them as naught. The cruel words " he is his money" are accepted as overriding the whole course of the legislation.

These critics have overlooked the well-known fact that speech and writing exhibit an extraordinary servility to familiar words and phrases. Laws and customs of prehistoric ages were contemporaneously summarized in pithy sayings and though such laws and customs were from time to time changed and ultimately discarded, the popular phrase enjoyed and enjoys a stupid immortality.

"He is his money," when it was first uttered at a primitive period anterior to the Pentateuchal legislation, was, probably, a fairly correct statement of this particular social relation. In the lapse of time, the relation underwent a profound change, but the phrase lived on and even now survives in the text, as a pregnant reminder of archaic history. 
This is, by no means, the only instance in the Pentateuch of adherence to dead words and sayings. The legal conception that a man violating the law should be adequately punished, was, in pre-historic times, when the law of retaliation represented the stage of development which had then been reached, formulated in the maxim: "Life for life, eye for eye, tooth for tooth, hand for hand, foot for foot." This became a current phrase and was transmitted from age to age. Needless to say, it is not a statement of Pentateuchal law, and yet, in one form or another, it occurs three times in the Pentateuch. ${ }^{13}$ In each of the cases where it is used, punishment of offences is provided for, but not the punishment that would be required by the maxim..$^{\mathrm{I}}$

This maxim was, among the Hebrews of three thousand years ago, a mere phrase and yet it is to-day frequently quoted as a summary of Hebrew criminal law.

There is, of course, a real difficultiy in understanding the text, a difficulty which no translation that I know of has overcome.

The words nakom yinnakem are generally translated "shall surely be punished." Such an expression would be without any definite or practical meaning. It specifies neither the kind nor the quantum of punishment and gives no clue as to who is to administer it. The probability is that the words constitute a technical law-term. Rashi understands it to mean "he shall die by the sword,"15 relying on the law of Num. 35.18: "If he smote him with a hand-weapon of wood whereby a man may die, and he died, he is a murderer; the murderer shall surely be put to death." He opines, however, that when death is thus. instantaneously produced by the master's chastisement of

${ }^{13}$ Exod. 21.23, 24, 25; Lev. 24.20; Deut. 19.21.

14See my Ancient Hebrew Law of Homicide, pp. 119-125.

${ }^{15}$ The expression hereb nokemet (the avenging sword) is found in Lev. 26.25. 
the slave, there must have been something more than the customary rod wherewith masters were entitled to punish slaves, something answering to the expression in the Numbers text, something which added a deadly quality to the rod. The fair inference from the text is that when death resulted immediately, the law presumed that this deadly quality was present and this presumption was not to be contradicted. If, however, the slave did not die on the same day, the presumption did not hold and therefore the master was not guilty of murder, he having exercised the ordinary right of corporeally chastising his slave, and the fact that by the slave's death the master lost a valuable piece of property, heightened the presumption of his innocence of murder when death did not immediately follow.

Under all the circumstances we need not hesitate to accept Professor Benzinger's view, which is strikingly fortified by Kent and Bailey in their excellent one-volume "History of the Hebrew Commonwealth." These are their words: "The chief claim of the Hebrew world to our regard lies in the fact that the ideals of democracy which to-day are winning acceptance among all civilized races first developed within this area. . . ." "It was in the soil of the barren steppe lands that encircle Palestine and among the nomadic tribes of the wilderness that the seeds of democracy first took root". . . . "Their ideas regarding the fundamental rights of man and his duties to his fellow were expressed in definite laws, and all later democratic legislation is largely an unfolding of what is there set forth in principle." ${ }_{16}$

"From Israel has come a moral code based on the Ten Commandments, which expresses, as well as mere laws can, the fundamental duties of man to God and to

${ }^{16}$ History of the Hebrew Commonwealth by Albert. Edward Bailey and Charles Foster Kent, New York, 1920, pp. 13 and 14. 
his fellow-man. It sprang from an instinct for freedom and brotherhood, perhaps the earliest and certainly the most persistent manifestation of that instinct among the ancient peoples of the world. It is this code that is the basis not only" of the constitutions but also of the everyday life of all the great democracies of the present day." ${ }^{57}$

The most persuasive evidence of the Hebrews' aversion to slavery is that there is no mention anywhere that in the course of the conquest of Canaan, they reduced or endeavored to reduce any of the native peoples to slavery. It is true their lands were taken from them by the conquerors, but they were neither exterminated nor driven out nor enslaved.

To understand the situation it is necessary to get a correct view of the Hebrew invasion of Canaan. We have already mentioned that the movement began not by marching in a direct line for the coveted land, but to take as the proper starting-point, the land east of the Dead Sea and Jordan. The inhabitants of that section were overcome and the Hebrews had thus acquired their base of operations. In consequence of the action of the tribes of Reuben and Gad (later joined by the half-tribe of Manasseh) in waiving all claim to a share of Canaan, that coveted area was to be divided among a smaller number of tribes than had been originally intended. The two tribes Simeon and Levi were also excluded, and had no part, as tribes, in the war against Canaan or in the division of the conquered land.

The ancient poem called "the Blessing of Jacob" seems to point to the exclusion of these two tribes from the fellowship of the others, by reason of reprehensible conduct. Their doom is pronounced in these words: "I will divide them in Jacob and scatter them in Israel." 18

While we have no authentic details of the fate of the 17Ibid., p. 355.

${ }^{18 G e n . ~ 49.7 . ~}$ 
Simeon tribe, the great probability is that it was disintegrated and that its members attached themselves to any of the other tribes that they preferred or that were willing to receive them.

Levi too ceased to exist as a tribe, though it finally achieved a re-integration of a kind. It had not a tribal territory of its own, but its members obtained slices in sections of the other tribes. It regained too a tribal consciousness and reached a position of dignity as guardian of the law and of the sanctuary.

In the narratives of the war neither Simeon nor Levi is mentioned. Levi, however, obtains a favorable notice, in accordance with events that happened long after. The reason for its non-participation is stated to be that it was "to bear the ark of the covenant" and that "the Lord is his inheritance." ${ }_{19}$

There were thus left but nine tribes that were to share the land of Canaan among them. The military authorities evidently made a theoretical plan of the country, dividing it into nine districts, to the conquest of each one of which a particular tribe was assigned. Naturally the conquering tribe was to be settled on the territory it had acquired.

For the great enterprise which they were about to undertake, the Hebrews had certain qualifications and perhaps greater disadvantages. Their experience in agriculture was in effect characterized as inadequate. "The land whither thou goest in to possess it, is not as the land of Egypt, from whence ye came out, where thou didst' suw thy seed, and didst water it with thy foot, as a garden of herbs; but the land whither ye go to possess it, is a land of hills and valleys, and drinketh water as the rain of heaven cometh down." 20

19Deut. 10.8, 9.

${ }^{20}$ Deut. $11.10,11$. 
And the contingency is foreshadowed "that there shall be no rain, and the ground shall not yield her fruit; and ye perish. . ." ${ }_{2 x}$ Moreover in the many arts and industries of Egypt they had not had a large share. They had, naturally viewed and admired the great works scattered through that country, but their part in adding to them, was, according to our accounts, humble. "They (the Egyptians) did set over them (the Hebrews) taskmasters to afflict them with their burdens. And they built for Pharaoh store-cities, Pithom and Raamses." "And they (the Egyptians) made their (the Hebrews') lives bitter with hard service, in mortar and in brick, and in all manner of service in the field. . . . "22

Nevertheless, the prospect was one of great hopefulness. Canaan loomed before them as a land containing "great and goodly cities which thou didst not build and houses full of all good things which thou didst not fill, and cisterns hewn out which thou didst not hew, vineyards and olive-trees which thou didst not plant." "A good land, a land of brooks of water, of fountains and depths springing forth in valleys and hills; a land of wheat and barley and vines and fig-trees and pomegranates; a land of olive-trees and honey; a land wherein thou shalt eat bread (lehem) without scarceness, thou shalt not lack anything in it; a land whose stones are iron and out of whose hills thou mayest dig brass." ${ }^{23}$

And they were to be the owners of this land wherein they would prosper not only in agriculture but in the arts and in commerce. Visions of imitating the glories of Memphis and Thebes in a capital city of their own also floated before their minds. ${ }^{24}$

Confident of easy victory they gave little thought to the natives whose lands they were to take. They would

21Deut.11.17. $\quad{ }^{22}$ Exod. 1.11, $14 . \quad$ 25eut. 6.10, 11; 8.7, 8, 9.

${ }^{2}$ Deut. $12.5-14,21,26 ; 14.23-25 ; 15.20 ; 16.2-16 ; 17.8-10 ; 18.6 ; 26.2 ; 31.11$. 
straightway destroy "the Hittite, the Amorite, the Canaanite, the Perizzite, the Hivite and the Jebusite." 25

There were, however, voices counselling prudence and caution. A large settled population, they were warned, could not be disposed of suddenly: "The Lord thy God will cast out these nations before thee by little and little; thou mayest not consume them quickly, lest the beasts of the field increase upon thee." ${ }^{26}$

Moses did not live to cross Jordan and the leadership devolved on Joshua, whom the people, in eager anticipation, willingly followed. In this mood, caution was thrown to the winds. The cry was: "Clear the land of its inhabitants and we will go in and enjoy it." The course of events soon removed their illusions.

Joshua began by taking Jericho and destroying it with all its inhabitants, saving only Rahab and her kinsfolk. ${ }^{27}$ The city of 'Ai he treated with the same severity. ${ }^{28}$

Thereupon the campaign took another turn. A small section of the natives began to be intimidated. The Gibeonites, despairing of resistance by force, resorted to cunning and deception. They sent a deputation to the leaders of Israel and by false representations induced the latter to agree to a treaty of peace. ${ }^{29}$

This treaty was concluded under the belief that the deputation represented a territory beyond that which Israel had planned to conquer, "a very far country," to use their own words.

A few days later the fraud was discovered and a great popular clamor was raised that the treaty should be disregarded. The council, however, rejected these demands to revoke a word solemnly given, saying: "We have sworn unto them by the Lord, the God of Israel; now, therefore, we may not touch them." 30

${ }^{25}$ Exod. 23.23, 28; Deut. 20.17.

${ }^{27}$ Josh. 6.22-25.
23Josh. 8.26.
${ }^{26}$ Exod. 23.29; Deut. 7.22.

${ }^{29}$ Josh. 9.3-15. $\quad$ 30Josh. 9.19. 
At this point their Egyptian experience suggested the remedy. They had been gerim in Egypt ${ }^{3 x}$ and as such had been not only incapable of owning land, but had been subject to feudal servitude, an incident of which was, what in our modern states is called the corvée,- the liability to be called for a certain time in each year to labor on public works. In Egypt it was doubtless called the mas, the superintendents of the laborers on public works being known as sare missim. The latter word was apparently a plural form for a singular mas not used in the narrative. The labors which these feudatories had to perform were called siblot, ${ }^{32}$ the plural form of sebel, which word in another form is, in at least one other instance, used to describe mas-labor. 33

The result of the treaty with Gibeon, as modified, was that the Gibeonites lost their lands to the Israelites and were moreover reduced to a condition not unlike the peasants of the Middle Ages, that is to become laborers on the land, subject however in addition to being called upon to work for the state during a certain portion of the year.

"This we will do to them (the Gibeonites) and let them live; . . . So they became hewers of wood and drawers of water to kol ha-'edah." (Meaning: public service. $)^{34}$ And Joshua's speech to the deputation is ". . . There shall never fail to be of you bondmen, both hewers of wood and drawers of water for the house of my God." 35 And they acquiesced. ${ }^{36}$

This treaty with Gibeon became the key-note of the new policy. The sanguinary project of exterminating the natives and the more moderate purpose of driving them out were both abandoned. It was now resolved that the natives should be reduced to the condition which the

\footnotetext{
31Exod. 22.20; 23.9; Lev. 19.34; Deut. 10.19; 23.8. $\quad$ 22Exod. 1.11.

${ }^{23 G e n . ~ 49.15 . ~} \quad$ sJosh. 9.20, $21 . \quad$ 35Josh. 9.23. 38 Josh. 9.25-27.
} 
Gibeonites had submitted to. They were to become gerim (landless) and subject to the mas.

The tribes were now ready to go on with the tasks severally assigned to them. Their successes were at first not complete nor even very important. Not until the Northern tribes had formed a union and acted together did they succeed in subduing the natives and relegating them to the position of gerim subject to the mas. The account is set forth in the Book of Judges. ${ }^{37}$ While eight of the tribes, namely Manasseh, Ephraim, Zebulun, Asher, Naphtali, Dan, Judah and Benjamin had at least won some triumphs before the union of the tribes, Issachar had totally failed. The record in Judges is silent on this humiliating event. Our information, on the subject, is obtained from the ancient poem called the Blessing of Jacob, which contains this remarkable passage:

"Issachar is a large-boned ass, Couching down between the sheepfolds.

For he saw a rest-place that it was good, And the land that it was pleasant, And he bowed his shoulder to bear (lisbol), And became for mas-'obed." ${ }_{3} 8$

We have here the story of the only complete failure among the invading forces. Instead of subjecting the natives to the mas 'obed as did four of the tribes, or making treaties of amity with them, as did four other tribes, Issachar was itself overcome and made subject to the mas-'obed by the natives of the district. The prosperity and comfort enjoyed by the tribe in its new home is described in a tone of lofty contempt for a spirit so mean as to be satisfied with subjection however profitable.

It is only just to the memory of the Issachar tribe, to remember that in the decisive battle with Sisera it showed

'Jud. 1.19-25.

${ }^{28}$ Gen. 49.15. 
that it had redeemed itself. In the great ancient poem of Deborah ${ }^{39}$ its achievements are lauded: "And the princes of Issachar, were with Deborah; As was Issachar, so was Barak; Into the valley they rushed forth at his feet." 40 The accepted opinion seems to be that Barak, the general of the Hebrew army, and the victor in that glorious combat, was of Issachar, and it has even been suggested by respectable authority that Deborah herself was of that tribe. The fact that Tola of Issachar was one of the shofetim of Israel $^{4 \mathrm{I}}$ attests the regard in which the tribe came to be held.

The poem further shows that the isolation of these northern tribes had gradually yielded to a desire for a more or less intimate unity, and that this confederacy was known as Israel or Beth Joseph.

It was doubtless after this had been accomplished, that the conquest of the north country was completed and the mas 'obed was imposed on all the indigenous inhabitants who remained in the land. That some of them emigrated to the Judaic or southern territory would appear from a casual statement in Chronicles, in the account of Hezekiah's Passover. ${ }^{42}$ Enumerating the classes of participants in that high festival, it mentions "the gerim that came out of the land of Israel and dwelt in Judah." The attraction, probably, was that in Judah, they were not subject to the mas-'obed. 43

Whether some emigrated to other countries our records do not inform us. No conjecture on this point should omit to consider the scanty means of transportation at the time and the improbability of a great mass of people find-

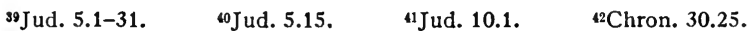

${ }^{4}$ The natives of the South country made a more successful stand against the invaders than did those of the North. "Judah could not drive out the inhabitants of the valley because they had chariots of iron," (Jud. 1.19), a significant forerunner of the effect of using tanks in the great world-war. "And the children of Benjamin did not drive out the Jebusites that inhabited Jerusalem; but the Jebusites dwelt with the children of Benjamin in Jerusalem, unto this day." (Jud. 1.21.) 
ing employment or sustenance in strange places within their reach.

The situation, however, presented another aspect far more important than mere passion or sentiment.

The Hebrews had suddenly come into control of a country whose land they divided among themselves and this land had to be cultivated. A relatively small number were capable farmers. Moreover the natives were practising all sorts of industries which the Hebrews had not mastered.

The statesmanlike genius evident in the whole movement did not, at this crisis, fail.

The solution proposed, adopted and carried into effect was that the native population, as a whole, should remain where they were. True, they lost their land-holdings to the Hebrews. They did not however lose their skill or industry, and these qualities were absolutely needed to maintain and develop the country. The precise terms of the understanding are of course inaccessible to us, but we have enough information to obtain a general idea of them.

That the relations of Hebrews with the ger were quite friendly, perhaps too friendly, appears sufficiently from the traditions.

We are told that "the children of Israel dwelt among the Canaanites, the Hittites, and the Amorites, and the Perizzites, and the Hivites and the Jebusites; and they took their daughters to be their wives, and gave their own daughters to their sons, and served their gods." 44

Ezekiel, perhaps in a mood of irritation, quotes the tradition thus: "Thine origin and thy nativity is of the land of the Canaanite; the Amorite was thy father, and thy mother was a Hittite." 45

uJud. 3.5. $\quad$ "sEzek. 16.3. 
And Ezra speaks as if the events of his time bore out the tradition. ${ }^{46}$

Let us, however, first ascertain by what name this non-Hebrew population was called. As they had become an element of the whole Hebrew social structure, the multifarious names of the relatively small groups into which they were divided would soon be abandoned. A new name would be applied to them to designate their whole body as against the body of Hebrews.

That name was ger, used sometimes in the singular and sometimes as a collective noun, though its plural form gerim was also used. A little reflection will supply the reason. Those natives were strangers in blood to the Israelites and there had been no acquaintance or intercourse with them. In those early ages, when consciousness of blood-relationship produced tribal bodies, all outside the ranks were strangers indeed. When the body of Israelites was brought in intimate contact with the body of natives, both of them felt that they were strangers to each other. The fact that the natives would soon become an integral body in close relationship to the activities of the new Hebrew nation could not at first mitigate the strangeness in blood, in experience, in activities and in religious practices. Moreover their national experience supplied a precedent. Though they had been settled in Egypt for centuries in relations somewhat similar to those which they now imposed on the Canaanites, they always viewed themselves as having been gerim in Egypt.47

It behooves us now to return to the other classes called strangers by the versions. First among these was the nokri. Him, the Hebrews looked upon as the hostile, the unmitigated alien.

Here are instances:

46Eza 9.1, 2 . $\quad{ }^{47}$ Exod. 22.20; 23.9; Lev. 19.34; Deut. 10.19. 
1st. There were two kinds of flesh abhorred by the Hebrews, that which dieth of itself (nebelah) and that which is torn of beasts (terefah).

The nebelah, odious as it was, might be sold to the nokri. ${ }^{8}$ The terefah was still more objectionable than the nebelah. The antique law was that it should be cast to the dogs. ${ }^{49}$ There is ground for the assumption that the rigidity of this rule was, in the course of time, relaxed, since an express ordinance forbade the eating of the terefah by Hebrew or by ger. $^{50}$ It is not hazardous to conjecture that it might be given or sold to the nokri, no allusion to him being made in this prohibitive ordinance.

2d. No ben-nekar could eat of the Passover. ${ }^{5 x}$

3d. An Israelite was not allowed to offer for sacrifice an animal procured from a ben-nekar. ${ }^{32}$

4th. The taking of interest or increase for money or goods loaned to another is a highly objectionable act, but it is nevertheless allowed in the case of a nokri. ${ }^{53}$

5th. No ben-nekar should be allowed in the Temple. ${ }^{54}$

6th. Perhaps the most emphatic example is presented by the spontaneous exclamation of the Levite while on his journey. When night fell and it was necessary to find shelter, his. companion pointed out a city that lay before them as a convenient stopping-place for the night. The Levite, horrified, replied: "We will not turn aside into a nokri city!"s5

7th. Isaiah reproaches Judah and Jerusalem that "they please themselves in the brood of nokri." ${ }_{56}$

8th. Zephaniah denounces those who wear clothes in nokri style. ${ }^{57}$

9th. Obadiah looks upon nokrim as mere pillagers. ${ }^{53}$

10th. Lamentations does the like. ${ }^{59}$

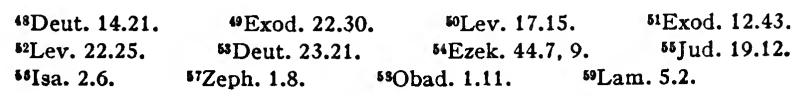


11th. The 114th Psalm says of the bene nekar that their "mouth speaketh falsehood, and their right hand is a right hand of lying." 60

The Book of Proverbs looks upon them as degraded and degenerate. The depth of infamy is reached by the nokriyah. ${ }^{6 \mathrm{x}}$

The worst fate that can befall a Hebrew is that the nokri or zar shall enjoy his substance, that "zarim be filled with thy strength and thy labors be in the nokri's house." 62

And a Hebrew has sunk low indeed when he has become muzar unto his brethren and nokri unto his mother's children; ${ }^{63}$ when the gerim of his house and his amahot look upon him as a zar and a nokri. ${ }^{64}$

While common opinion was hostile to the nokri, and the law, in a measure, reflected it, since the education of a whole people in new ideas is a slow process, there were loftier spirits whose souls were unhampered by prejudice. These had that wider vision which looks without fear into a distant future nobler and freer than the present. They foresaw a time when the hated nokri should become a brother. In the prayer of Solomon at the dedication of the Temple he speaks of "the nokri that is not of thy people Israel, when he shall come out of a far country for Thy name's sake . . . when he shall come and pray toward this house" and his supplication is: "Hear Thou in heaven, Thy dwelling-place, and do according to all that the nokri called to Thee for; that all the peoples of the earth may know Thy name to reverence Thee as doth Thy people Israel. . . " 65

In the magnificent vision of Isaiah, he sees kol hagoyim (all the foreign nations) "at the end of days" flock

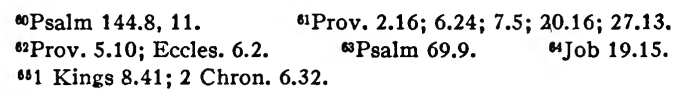


to the Temple and pledge allegiance to the God of Jacob and "they shall beat their swords into plowshares, and their spears into pruning-hooks; nation shall not lift up sword against nation, neither shall they learn war any more." 66 And Micah foresees the same happy result in the end of days, ${ }^{67}$ meaning, according to Margolis, ${ }^{68}$ the Messianic era.

When we reflect that these messages were delivered twenty-five centuries ago and view conditions as they are to-day, the long postponement of the happy time is fully vindicated.

The broad views above cited concerning the nokri may be supplemented by an incident of the most interesting character.

It will be remembered that Israel determined not to make its attack on Canaan from the south, but to establish its base of operations east of Jordan. The direct route to the desired point lay through the territory of Edom.

At this point Moses exhibited a regard for international law based on ethical principles, which is amazing for that early time. The narrative is related in the twentieth Chapter of Numbers:

"Moses sent messengers from Kadesh unto the King of Edom. Thus saith thy brother Israel. . . . We are in Kadesh, a city in the uttermost of thy border. Let us pass, I pray thee, through thy land; we will not pass through field or through vineyard, neither will we drink of the water of the wells; we will go along the king's highway, we will not turn aside to the right hand nor to the left, until we have passed thy border."

And Edom said unto him:

"Thou shalt not pass through me, lest I come out

sIsa. 2.2-4. $\quad 67$ Micah 4.1-4.

'Margolis' Commentary on Micah, pp. 42, 43 (J.P.S., Philadelphia, 1908). 
with the sword against thee." And the children of Israel said unto him:

"We will go up by the highway, and if we drink of thy water, I and my cattle, then will I give the price thereof; let me only pass through on my feet; there is no hurt."

"And he said, Thou shalt not pass through. And Edom came out against him with much people and with a strong hand. Thus Edom refused to give Israel passage through his border; wherefore Israel turned away from him." ${ }_{69}$

The object to be attained was practicable by a march through the territory of the Amorites whose King was Sihon.

Moses then sent to Sihon, a message substantially similar to that which had been sent to Edom, omitting of course to call Israel brother to the Amorite because they viewed each other as strangers whereas the Edomite was looked upon as descended from the brother of Israel's ancestor Jacob.

Sihon, however, not only refused to grant the request but gathered his army and attacked Israel at Jahaz.

"And Israel smote him with the edge of the sword and possessed his land from the Arnon unto the Yabbok even unto the children of Ammon; for the border of the children of Ammon was strong. And Israel took all these cities and Israel dwelt in all the cities of the Amorites, in Heshbon, and in all the towns thereof. For Heshbon was the city of Sihon the King of the Amorites, who had fought against the former King of Moab and taken all his land out of his hand even unto the Arnon."

"Thus Israel dwelt in the land of the Amorites."70

The aloofness of the great mass of Hebrews from the nokri, is in striking contrast to their position towards the ger.

${ }^{69 N u m}$. 20.14-24. $\quad{ }^{70 N u m ~ 21.22-31 . ~}$ 
We have already advanced the hypothesis that the bulk of the native population remained in the land and became feudatories of the conquering Hebrews, subject likewise to the mas or corvée, which is the liability to be called on to labor on public works for a limited period.

That the ger was an important factor in the laborforce of the Hebrew commonwealth is amply attested by the records.

We have, for instance, this narrative:

Moses is represented, as having, near the close of his career, addressed all Israel, reciting at the same time the several classes composing the nation, ${ }^{7 x}$ to wit: "All the men of Israel, your little ones, your wives, and THY GER that is in the midst of thy camp, from the hewer of thy wood unto the drawer of thy water."

If the ger here referred to had been merely alien outsiders visiting the country or temporarily sojourning in it, there would have been little reason to include them as an important element of the people on this solemn occasion. There would have been even less ground for using the possessive pronoun and calling them THY ger. This possessive expression implies not only close relationship, but also superiority, a power of command, which would be inappropriate to express the condition of friendly visitors, but would aptly characterize the relation between employers and employees. We are not however compelled to rely on inference alone. The phrase added defines their condition, they are the "hewers of wood and drawers of water," a popular expression describing any kind of common labor.

There are other instances of a similar use of the word. The Sabbath commandments in Exodus and Deuteronomy $^{72}$ direct the master to prohibit work on the Sabbath not only by his family and his slaves but "by THy ger that

${ }^{n}$ Deut. $29.19,10 . \quad{ }^{72}$ Exod. 20.10; 23.12; Deut. 5.14. 
is within thy gates." Such a command is, of necessity, addressed to an employer who might otherwise exact Sabbath service from an alien employee who was not a worshipper of the God of Israel.

A similar prohibition is contained in the ordinance commanding the observance of the tenth day of the seventh month (Atonement Day). ${ }^{73}$

More striking still is the language attributed to Moses in charging the judges: "Hear the causes between your brethren and judge righteously between a man and his brother and (between a man) and His ger." 74 It is difficult to imagine causes of conten tion with mere strangers, whereas differences between employer and employee have always arisen. And here again it is necessary to note the possessive pronoun (HIs ger).

The unsophisticated historical evidence seems conclusive of the matter. Solomon, intent on increasing the splendor of his reign, entertained magnificent building schemes. He built not only the Temple but constructed the fortifications of Jerusalem, the royal palace and other notable structures. He also built Gezer, Beth-Horon the nether, Baalath, Tadmor in the wilderness and other cities. ${ }^{75}$ In carrying on these projects he was doing what his father, King David, had dreamed of and projected.

Needless to say, the work required a large force of laborers, and the only practicable mode of obtaining them was by the enforcement of the mas, the corvee to which the conquered Palestinian natives had been subjected. David had seen this clearly and had begun by systematizing the institution putting at its head a man of extraordinary ability, Adoniram, whose office is described as being "over the mas," ${ }^{76}$ what in modern parlance we would call a "Minister of Labor" in the King's Cabinet, which position

"2Lev. 16.29. "7Deut. 1.16. Tr1 Kings 9.15-19; 2 Chron. 8.1-6.

72 Sam. 20.24 . 
he continued to hold under Solomon ${ }^{77}$ and under the latter's successor Rehoboam, ${ }^{78}$ a period of remarkable length, seeing that the duration of Solomon's reign was about forty years ${ }^{79}$ to which must be added the time he held office under David and under Rehoboam.

David's first step was to take a census of all the gerim men in the land of Israel..$^{80}$ There were, however, circumstances which hindered him from realizing his projects. Under Solomon everything was ready. Adoniram took a new census of these gerim men, and their number was found to be 153,600 , from which figure it is fair to infer that the whole ger population of Israel (women and children included) was perhaps three quarters of a million.

We are not left in doubt as to who these gerim were. The account is explicit: "All the people that were left of the Amorites, the Hittites, the Perizzites, the Hivites and the Jebusites, who were not of the children of Israel; even their children that were left after them in the land. . ."8x

The census being completed the next step was to levy the mas. The architects needed 10,000 men to work steadily, and these were to be taken from among the gerim. As has already been said, these gerim were employed by the Israelites, the men of the northern section, in agricultural and other labors, though their largest and most important industry was agriculture.

The mode in which the mas was levied, was somewhat complicated and that for good and sufficient reasons. The Israelite farmers needed the gerim and deprivation of their service entailed loss and hardship. To reduce these disadvantages as much as possible, Adoniram devised this scheme:

The 150,000 gerim men were divided into five sections

771 Kings 4.6; 5.28. $\quad 781$ Kings 12.18; 2 Chron. 10.18.

${ }^{79}$ Solomon's reign is given as forty years in $1 \mathrm{Kings} 12.42$.

802 Chron. $2.16 \quad 811$ Kings 9.20, 21; 2 Chron. 8.7, 8. 
of 30,000 each. The first year one of these sections was drafted; another section was drafted for the second year, and so on, one section for the third, another for the fourth and another for the fifth year. It followed that the members of any one of these sections were not subject to be called for a second term of service until the fifth year after the expiration of their first term.

These sections of 30,000 men were thrice the number required by the architects. Each section was therefore subdivided into three sub-sections of 10,000 each, the latter being the number required. It followed that each of these sub-sections was held to the work for only four months in each year. To deprive the Israelite employer of a considerable number of his workmen for four successive months in the year would have been a serious hardship. The matter was therefore so arranged that each sub-section of 10,000 men should do its work not by continuously working for four months, but by working one month out of every three in the year of their service, so that each individual worked in the public service a total of four months in five years, that is one-fifteenth or six and two-thirds per cent of his time.

The outstanding feature of this mas levy was that it did not include the southland, the territory of Judah and Benjamin, while most of the magnificent structures to be built were to be located in the latter. Solomon appointed as Adoniram's chief deputy in Israel, a northerner of the northerners, Jeroboam ben Nebat, an Ephraimite. ${ }^{82} \mathrm{He}$ is described as a gibbor hayil (a mighty man of valor) and of untiring industry, and he was given charge "over all the labor of beth-Joseph" (the northland). Instead of faithfully performing the duties of his office, he did his best to rouse opposition to the enforcement of the mas. His

821 Kings 11.26; George Adam Smith's Historical Geography of the Holy Land. p. 319 , note. 
treachery being disclosed, he fled to Egypt where he remained till Solomon's death. ${ }^{83}$

Though the discontent of Northern Israel was not relieved, Solomon's reign was so imposing that no outbreak resulted. The work went on without disturbance, and the results were, as regards the reputation of the Kingdom, of the most flattering character.

At Solomon's death, however, the rebel-Jeroboamreturned to Palestine and resumed his activity. Solomon's son and successor, Rehoboam, was of a type far inferior to his celebrated father. From the very beginning of his career he blundered. The discontented northerners at once approached him and demanded relief from the mas. ${ }^{84}$ Jeroboam was their spokesman. Rehoboam haughtily refused, whereupon the northerners raised their old warcry "To your tents, O Israel," ${ }_{55}$ and openly rebelled. Rehoboam, unable to grasp the situation, sent poor old Adoniram to the north with orders to enforce the mas relentlessly. He was killed in the attempt, the Northland seceded, Jeroboam became its first king, Jerusalem was repudiated as the capital and Beth-el was set up in its place. ${ }^{86}$

Thus the kingdom was finally divided in the year 933 B.C., for a grievance which the Northerners had endured for decades. The mas which took from the employer six and two-thirds per cent of his ger's working-time was scarcely sufficient of itself to warrant the drastic step of secession. There was undoubtedly a feeling that the South was getting an unfair advantage of the North not only in monopolizing the results of this labor, but in not contributing its proportionate share thereof. Added the tactlessness of Rehoboam and the audacious ambition of Jeroboam, and there were ample materials to produce a cataclysm.

1 Kings 11.40. 81 Kings 12.3, 4. 851 Kings 12.14, 16.

81 1 Kings 12.29-33: Amos 7.13. 
One curious feature in connection with this subject is that many scholars understand the texts to mean that the Israelites themselves were drafted for public work and that this was the cause of the revolt. For this opinion there is no semblance of authority. There is not the slightest hint that they were ever made subject to the corvée, whereas all the texts concur in stating that the gerim were so subject. When the text tells us that Solomon levied a mas on kol-yisrael, it plainly means that he drafted their employees and thus imposed a tax on the employers. ${ }^{87}$ We may assume that people three thousand years ago were not more eager to pay taxes than are our contemporaries, and that, then as now, they bandied charges that the taxes were unfairly levied, that they were excessive and that the products were unevenly distributed.

This aspect of the case many commentators and critics have overlooked and have in consequence invented the imposition of the corvée on the Israelites themselves, in the belief that nothing less than a severe personal grievance could have produced the great rebellion.

In the next lecture we will further consider the ger. 
IN the previous lecture the gerim were depicted as a great, perhaps the great labor force of the Hebrew commonwealth. Though described by all the Bible translators as strangers, the difference between them and the zarim and the nokrim, who are also called strangers was dwelt upon. In addition to these classes there were two other classes of so-called strangers mentioned, namely the Toshab and the Sakir, to investigate whom is our next problem.

About them there is no mystery. They are mere subdivisions of the ger.

When the natives were reduced to feudatories they had to face abnormal conditions. The majority of them were farmers but an important minority carried on other trades. The Hebrew vocabulary is rich in the names of such occupations. ${ }^{\mathrm{x}}$

The conquest had deprived the natives of their landholdings. Most of them had families to support. The

1The following list, which is far from complete, will show how varied were the occupations of the inhabitants:

The Omman (Cant 7.2) is a master-workman, an artist.

The Ofeh (Hosea 7.6) is a baker.

The Oreg (Isa. 19.9) is a weaver.

The Boneh (2 Kings 22.6) is a builder.

The Mekareh (Psalm 104.3) “" “”

The Gallab (Ezek. 5.1) is a barber.

The Dayyag (Isa. 19.8) is a fisherman.

The Dawwag (Ezek. 47.10) “ “.

The Hobel (Ezek. 27.9) is a sailor.

The Mallah (Ezek. 27.29) "

The Hobesh (Is . 3.7) is a surgeon.

The Rofe (2 Kings 20.5) is a physician.

The Harash (1 Sam. 13.19) is a metal-worker.

(2 Sam. 5.11) is a wood-worker.

(2 Sam.5.11) is a worker in stone. 
obvious resource was to utilize their knowledge by working for the victors. The latter were not in the best condition. They had not the requisite number of skilled farmers and artisans to carry on the variegated business of the country. They needed the labor of the dispossessed natives. The result was an arrangement whereby the bulk of the native population remained where they were. They became settled as employees on the land of which they had been the owners. And these settled gerim were called toshabim (settled, a word related to yashab, to sit, just as in English, sit and settled are related). They were not employed for a season or for a limited period, but they and their progeny after them were to be on the land indefinitely-a settled peasant population.

That a minority of the natives, especially the artisans and the unmarried men, were reluctant to enter into such a service was only natural. They preferred to work for a period expressly limited and to be paid daily wages. These

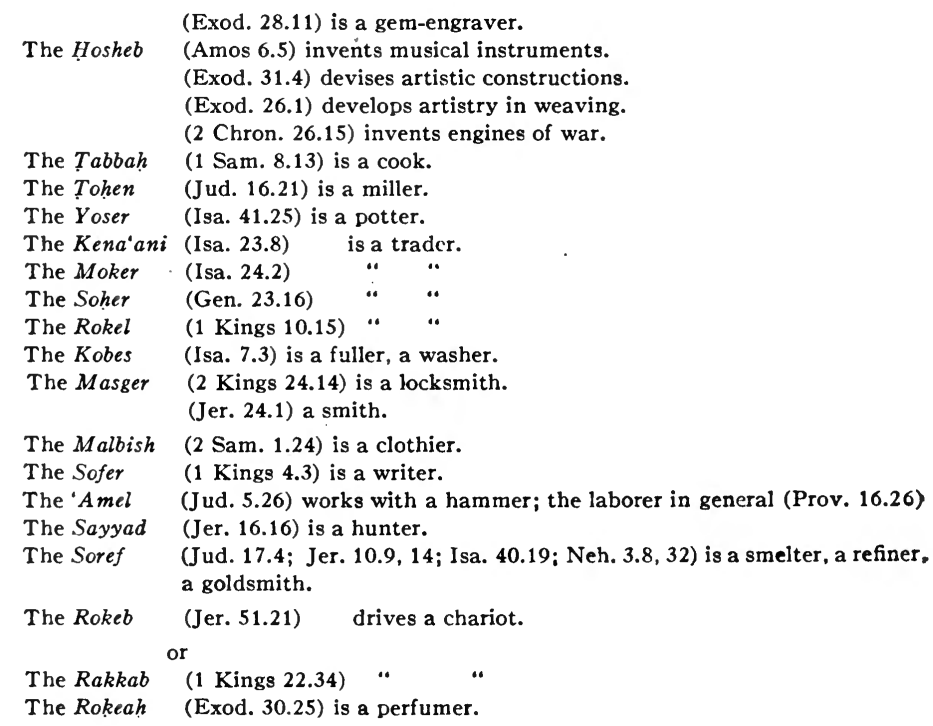


constituted the sakir class of the ger. The term of a sakir's work-contract was called yeme sakir ${ }^{2}$ or shene sakir. ${ }^{3}$ While ordinarily yeme sakir would mean sakir's days, yet the word yom besides its usual meaning of $d a y$, also signifies time, instances of which meaning are given in BrownDriver's Hebrew Lexicon. ${ }^{4}$ It is in this sense that it is used here, and it indicates that the sakir was hired, not from day to day, but for a fixed period. And this fixed period was, in the beginning, more than one year, as the expression shene sakir (literally sakir's years) shows. The probability is that the term of his employment was for three years. So may fairly be understood the injunction to a master releasing his Hebrew slave at the end of six years (which was the limit of a Hebrew slave's service) on the expiration of which he was to go out free. These are the words: (A.V.)

"It shall not seem hard unto thee, when thou sendest him away free from thee; for he hath been worth a double hired servant (sakir) to thee in serving thee six years."'s

It is true that many modern scholars haughtily reject this view, but it is that of Ibn Ezra, who fortifies it by Isaiah's words in foretelling the doom of Moab, and it may well be accepted:

"Within three years, as the years of a sakir (shene sakir) and the glory of Moab shall wax contemptible." 6

The probability is that in the course of time, as circumstances changed, the three-year term of the sakir's

2Lev. 25.50; Job 7.1; 14.6. IIsa. 16.14. $\quad$ 4P. 399, sect. 6. 'Deut. 15.18.

Notwithstanding my repugnance to entering upon the slippery path of textual criticism, I venture in this connection to make the suggestion that the text originally read, not mishneh sekar sakir, but mishneh shene sakir. That an ancient scribe, who has since been uniformly followed, might easily have made this blunder, plainly appears when we reflect that he had three words to copy, that he kept these in mind, and that the middle word was closely related to the first. While writing he made it closely related to the third instead of the first, a mistake the like of which many of us have made since his day. Had he acted otherwise than mechanically, he could not have escaped the reflection that the wage of the sakir was paid every evening, while the reward of the 'ebed was principally, if not altogether, in kind, and could bear no analogy to the sakir's daily wage payment.

Isa. 16.14. 
contract was reduced to one year. This may fairly be inferred from the expression used concerning the term of a Hebrew who has sold himself as a slave to a ger we-toshab. Instead of being doomed to perpetual servitude he must be viewed as a sakir shanah be-shanah (a sakir from year to year). ${ }^{7}$

Our thesis that the ger were composed of the two classes toshab and sakir seems provable from the records.

They are grouped together in several instances in a way that shows their close connection in status.

A striking example of this is to be found in the impor-

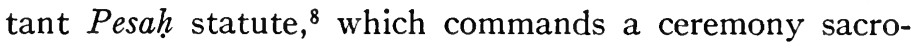
sanct, in commemoration of the Exodus from Egypt. It is therefore of special concernment to Israelites and participation in it by non-Israelites is eschewed. As there are many of the latter connected with Israel, the relations of the several groups are carefully defined. The groups spoken of are the following:

a) The whole congregation of Israel ${ }^{9}$

b) The ben-nekar (the unmitigated alien) ${ }^{\text {ro }}$

c) The miknat kesef (purchased nokri slave) ${ }^{\mathrm{II}}$

d) The toshab and sakir ${ }^{12}$

e) The ezrah ha-areș ${ }^{13}$

f) The 'arel (uncircumcised) ${ }^{\mathrm{I}}$

g) The ger $^{15}$.

Superficially read, there would appear to be six groups of outsiders. Careful examination shows that there is not so great a number. The ultimate test is, that one who has not been initiated into the covenant of Abraham (the 'arel), may not eat of the Paschal lamb. This condition of inadmissibility was, of course, normal in the case of the ben-nekar, the man who was and would remain a complete

\footnotetext{
Thev. 25.53. BExod. ch. 12 and the Supplement thereto Num. 9.1-14.

Exod. 12.47. $\quad{ }^{10}$ Ibid. 12.43. 11 Ibid. 12.44.

19Ibid. 12.48, 49. $\quad$ "I Ibid. 12.48.
} 
outsider. The miknat kesef was a ben-nekar by origin, but according to the traditional custom, it was the duty of the master to initiate his slave whether house-born or purchased $^{16}$ and hence the ordinance admits him to participate after such initiation. ${ }^{17}$

The toshab and sakir are here named together, and their participation in the Paschal ceremony is forbidden. Respecting them there would appear to be no alleviation. And yet such a state of affairs seems highly improbable. The purchased nokri slave, may, after complying with the condition, join in the festival. Respecting the house-born slave not a word is said because his initiation into the Covenant is assumed as a matter unquestionable.

The toshab and sakir work by their side for the same master. Keeping in mind the imitative and assimilative qualities of humankind, it is incredible that they would not want to do what not only the master did, but what the slave, whom they looked down upon, had the privilege of doing. It is equally improbable that the ordinance would sternly exclude the toshab and the sakir if they were willing to leave the 'arel class. Nor did the ordinance do so. When it permitted the ger, after the admission of himself and his males into the Abrahamic covenant, to partake of the Paschal lamb, it was merely substituting the term ger for its species, toshab and sakir. Bertholet, who has studied the subject more closely perhaps, than any other commentator, is of this opinion. These are his words: "Vielmehr ist ger der Allgemeinbegriff, unter den sich toshab subsumiert." 18

If these views are correct it would follow that the only class absolutely inadmissible to participate was the nokri, the ben-nekar, the hostility to whom was dwelt upon in

16Gen. 17.13. ${ }^{17}$ Exod. 12.44.

18Bertholet, Die Stellung der Israeliten und der Juden zu den Fremden, p. 159. 
the preceding lecture. Though the gerim, whether toshab or sakir could join in the festival, they were perfectly free to refrain from so doing. While their gradual assimilation was likely to occur, no pressure was to be brought to hasten the process. The words are: "If the ger . . will keep the passover. . ." ${ }^{\mathrm{r}}$ leaving the matter to their option and initiative.

The groups mentioned have now been considered excepting only the ezrah ha-ares. The versions present various translations but with vexatious unanimity understand this term to mean invariably the Israelite himself.

To this rendering there are serious objections. To consider it now would be a hindrance to the elucidation of the main questions and it must therefore be deferred till later.

This much may, however, be said at this point. In our view the ezrah ha-ares or as it is alternatively written, the ezrah are terms that in the majority of instances mean Israel but in the rest have another meaning, the phenomenon being due to changes arising in the course of Hebrew history.

We will now return to our toshab and sakir. They are mentioned together in the regulations concerning the priesthood. The latter are allowed the kodashim (holy things) for their sustenance, but outsiders are excluded. Among these outsiders are the priest's toshab and sakir. They may not eat of it, though his slaves purchased and home-born are allowed to eat of it. ${ }^{20}$ The difference between these two kinds of laborers is that the slave, as was explained in the previous lecture, has virtually become a member of the family, and as such joins in the family worship, whereas the toshab and sakir contemplated by the ordinance are freemen who are not to be persuaded to ${ }^{10}$ Exod. 12.48. $\quad 20$ Lev. $22.10,11$. 
become proselytes. And even if they left the 'arel class they would still be excluded from the kodashim, because the ordinary Hebrew layman (here called zar) is equally barred. ${ }^{2 x}$

The next instance relates to the produce of the seventh (the sabbatical) year when there must be neither sowing nor reaping. What the land spontaneously produces may be used for food

$$
\begin{aligned}
& \text { by thee (the owner) } \\
& \text { by thy 'ebed (slave) } \\
& \text { by thy amah (female slave) } \\
& \text { by thy sakir } \\
& \text { by thy toshab'. }
\end{aligned}
$$

Here the sakir and the toshab are placed in the same category with the slave and are in like manner spoken of possessively, indicating that there is the relation of master and servant. There is no mention of thy ger as in other analogous instances, for the obvious reason that the classes mentioned are the two species of the genus ger.

In the preceding lecture the same use of the possessive pronoun in connection with the ger was shown and dwelt upon.

And, last but not least, the position of the sakir and toshab as employees is emphatically illustrated in the case of a Hebrew who has become impoverished and has sold himself to a prosperous man of his own nation. Though the greed of the buyer and the desperate straits of the seller may have co-operated to make a contract whereby the poor wretch was to become an 'ebed (slave), the law steps in and annuls it as contrary to the public policy of the state. The poor man's status is to be that of ger we-toshab or alternatively of sakir or of toshab,,$^{23}$ the various names being practically equivalent to ger.

${ }^{21}$ Lev. 22.10. $\quad{ }^{22}$ Ibid. 25.4-6. $\quad{ }^{23}$ Ibid. 25.34, 40. 
In this connection it is well to consider the case of the Hebrew who has become impoverished and has sold himself to a prosperous ger we-toshab or to one of the latter's kin. However stringent the contract, the law reads into it a provision that the Hebrew may at any time be redeemed on fair terms, either by himself if he become able, or otherwise, by any of his kin. In no event can he be held beyond the jubilee year. In arranging the terms of redemption the time already served is to be used in the computation as if the poor man had been serving sakir's time (yeme sakir). Indeed he is to be considered and treated as a sakir shanah be-shanah (a sakir from year to year). ${ }^{24}$

A comparison of the two cases invites attention to facts that are noteworthy. The outstanding feature is that the ger we-toshab is in a position to employ a Hebrew to work for him. The desire on the ger we-toshab's part to call for such help is based on his prosperity and on a form of it which is nowhere expressly mentioned but seems necessarily implied. He is a peasant living with his family on a Hebrew's land, deriving his and their sustenance from it, with perquisites perhaps in the form of wages, which are unascertainable from the records. A Hebrew landowner alongside of him is too impoverished to continue on his land any longer and must seek a means of earning a livelihood for himself and family. He makes an arrangement with the ger we-toshab whereby the latter will employ him, perhaps leasing to such employer for a limited term the land which he himself can no longer manage. While the ger we-toshab may not own land there is no authority for believing that he might not lease it for a limited term. If he does so, he may not employ the unfortunate owner as a peasant (toshab) but must hire him as a sakir, a laborer, whose wage must be paid daily. 
In this connection it may not be amiss to remember that the sakir is also capable of attaining a certain prosperity. Probably such an achievement was rarer in the case of a sakir than in that of a toshab, but it was practicable.

The only recorded instance is that of a sakir who owns an animal and hires himself out to work with it, naturally for a wage much greater than he would earn for his own work without such aid. The text has given endless trouble to the translators. The King James version renders it thus:

"And if a man borrow aught of his neighbor (rea"), and it be hurt, or die, the owner thereof being not with it ('immo), he shall surely make it good. But if the owner thereof be with it ('immo), he shall not make it good; if (im) it be an hired thing (text: sakir) it came for his hire."25

The English Revision makes it:

"And if a man borrow aught of his neighbor and it be hurt or die, the owner thereof not being with it, he shall surely make RESTITUTION. If the owner thereof be with it he shall not make it good; if it be a hired thing (sakir) it came for ITs hire."

The J.P.S. version is like the English Revision except that it renders the last clause thus: "if it be a hireling (sakir) he loseth his hire."

The King James version and the English Revision make of the sakir, a hired thing. The J.P.S. version on the other hand appears to make the sakir, a person (as he really is), but what the meaning of its whole phrase is passes my understanding.

There appears to have been a general obsession that a sakir could never be rich enough to own an ox or a cow, and therefore to conceive him as hiring himself out to work with his animal did not occur to them. 
Kautzsch in his German version of the Scriptures is unable to give a satisfactory translation and therefore leaves the last clause untranslated, giving his reasons in a note, of which the following is a translation:

"The last phrase is of quite uncertain meaning. It is usually translated thus: 'If it (the animal) was hired, the loss is on the hire', i.e. the loss is to be reckoned and covered by the hire. But, in the first place, the word sakir always means a day-laborer, and in any event, it would be monstrous to consider the value of the animal as being covered by the hire, which, after all, is but a small fraction of its value. On the whole, therefore, it would seem that this additional phrase has no bearing on the subject of hiring an animal and refers only to the negligence of a hired man in failing to care for the loaned animal. In that view, the phrase would mean: 'If it be a hired man who is responsible for the loss, it falls on his wages, i.e. he must work till he earns enough to pay for the loss.' " ${ }_{26}$

Kautzsch was on the right track, though he wandered from the path and failed to reach the goal.

The difficulty is caused by the failure to grasp the special meaning of the word $\mathrm{rea}^{\prime}$ and the particular intimation conveyed by the word 'immo (beginning with an 'ayin) and by the word im (beginning with an alef).

It is however the word rea ${ }^{\prime}$ which is most important in this connection. The versions agree in rendering it "neighbor" which is its usual signification. Here, however, it has another and a special meaning, though at bottom, this special meaning has the same ethical implications as the general meaning. This question, "who is my neighbor," is the text of a fine piece of Midrash in Luke. ${ }^{27}$ We cannot however ascertain exact legal definitions by hortatory exposition, however beautiful.

\footnotetext{
${ }^{26}$ Kautszch, Die Heilige Schrift des alten Testaments, Freiburg, i. B. and Leipzig' 1894. Beilagen p. 2 . 
It will be remembered that the great body of native workmen were called ger (stranger). As the new lords of the land developed its industries, there inevitably arose considerable classes of Hebrew laborers, men, who, either had lost the land originally assigned them or some perhaps who had never received any. ${ }^{28}$ These Hebrews came by degrees to practise the various trades at which the ger worked. With agriculture they were more or less familiar and doubtless the majority of these workmen chose farming. Thus they worked alongisde of the ger. The national pride forbade the calling of these brethren ger, though this word had practically come to mean "laborer." In contrast to the ger (stranger) they called their Hebrew workman, rea' (neighbor, friend). It is to be noted that though the Hebrews balked at calling their laboring tribesman ger, they did in time call such of them as worked for daily wage, sakir, though the latter were originally one section of the ger.

The following ordinance shows this use of the word:

"Thou shalt not oppress a sakir 'ani we-ebyon (the versions render: a hired servant that is poor and needy) whether he be of thy brethren or of thy ger that are in thy land within thy gates. In the same day thou shalt give him his hire, neither shall the sun go down upon it; for he is poor ('ani) and setteth his heart upon it. . . . ."29

${ }^{28}$ Num. 1.2, 3 tells us that prior to the invasion of Canaan, a census was taken of all the males "from twenty years old and upward, all that were able to go forth to war in Israel." Upon the basis of the registry so made the conquered land was to be divided . The question arises whether "and upward" was intended to include men of senile age or whether there was a maximum age for military service. That there was some limit seems intrinsically probable, and this probability is enhanced by the narrative which makes Caleb, in his eighty-fifth year declare himself as still fit for war (Josh. 14.11). Had he been on the registry, such a remark would have had no reason. It is still further strengthened by the statement of Josephus (Antiq. Book III, ch. 12, 4) that the limit was fifty years. Though he is not always to be relied on, he is in this instance probably right, especially in view of the current opinion that man's normal span of life is seventy years (Psalm 90.10). If this hypothesis be correct it would follow that some were landless from the very beginning. Add to this the inevitable differences in the fertility of soil and in the ability and efficiency of the owners, and causes for distress and impoverishment will not be wanting.

${ }^{20}$ Deut. 24.14, 15. 
Returning now to our rea we find in the prophetic writings satisfactory evidence of its use to mean workman.

Jeremiah in his great sermon on morality delivered at the gate of the Lord's house, exhorts his hearers as follows:

"Thoroughly amend your ways and your doings; thoroughly execute justice between a man and his rea', oppress not the ger, yatom or almanah." 30

Note the parallelism between the rea' and the ger. More explicit still is his cry against the King Jehoiakim:

"Woe unto him that buildeth his house by unrighteousness,

And his chambers by injustice,

That useth his rea"s service for nothing

And giveth him not his hire (po'alo)." ${ }^{\mathrm{x}}$

And comparing the King unfavorably with his father, he dwells on the latter's justice and righteousness in that he judged the cause of the 'ani and the ebyon, whereas the son is a covetous oppressor. ${ }^{32}$

Again in Zedekiah's time he reproaches all the powers of the state, namely, the princes of Jerusalem, the sarisim and the priests and the whole 'am ha-ares ${ }^{33}$ with dereliction in not securing liberty for all including every man's rea ${ }^{6}{ }^{34}$

Ezekiel is equally bitter. His reproaches directed to the princes of Israel enumerate among their other delinquencies that they have dealt by oppression with the ger, the yatom, the almanah ${ }^{35}$ and the rea ${ }^{4} .^{36}$

Proverbs has this significant passage: $\mathrm{He}$ that despiseth his rea' sinneth, but he that is gracious to the 'aniyyim happy is he. ${ }^{37}$

There are passages in the Pentateuch on similar lines:

"A ger thou shalt not wrong, neither shalt thou oppress him; for ye were gerim in the land of Egypt. Ye shall

$\begin{array}{lccr}{ }^{30} \mathrm{Jer} .7 .5,6 . & { }^{31} \mathrm{Ibid} .22 .13 . & { }^{32} \mathrm{Ibid} .22 .15-17 & { }^{33} \mathrm{Ibid} .34 .19 . \\ { }^{24} \mathrm{Ibid} .34 .17 . & { }^{35} \text { Ezek. 22.7. } & { }^{36} \mathrm{Ibid} .22 .12 . & { }^{37} \text { Prov. 14.21. }\end{array}$ 
not afflict any almanah or yatom. . . . If thou lend money to any of my people, even to the 'ani 'immak (versions: the poor with thee) thou shalt not be to him as a creditor, neither shall ye lay upon him interest. If thou at all take thy rea"s garment to pledge, thou shalt restore it to him by that the sun goeth down; for that is his only covering, it is his garment for his skin; wherein shall he sleep? . . ".38

Note here the classification: ger, almanah, yatom, 'ani 'immak, rea'. Again: "Thou shalt not oppress thy $r e a$, nor rob him; the wages of a sakir shall not abide with thee all night until the morning." ${ }_{39}$

Here rea' and sakir are in juxtaposition, if indeed they are not alternative expressions meaning the daylaborer.

And now as to the word 'immo.

This word ' $i m$, among its numerous meanings, has one which expresses the idea of employment. The versions simply translate "with" apparently ignoring the special meaning here present.

Instances of the use of the word with this special meaning are not wanting. We have an interesting series of passages relating to an important event in the life of the patriarch Jacob.

When he had roused his brother Esau's enmity, his mother feared for his life and begged him to go to Haran to her brother Laban "and tarry with him a few days," until Esau's fury should abate. ${ }^{40}$ Though mother and son knew that it was not a trifling journey to Paddan-aram, and that Fsau's wrath was not so short-lived, that a few days or a short time would see matters adjusted, yet need we not quarrel with the mother's loving belittlement of the difficulty. She did not intend to be understood literally and Jacob easily divined her intention. Indeed the same

${ }^{88}$ Exod. 22.20-26. $\quad{ }^{39}$ Lev. 19.13. ${ }^{40} \mathrm{Gen}$. 27.42-45. 
expression occurs in the narrative of Jacob's love for Rachel which was so great that his service of seven years for her seemed to him but "a few days." 4 I

Rebecca did not expect her son to pay a visit to her brother in order to enjoy a genteel vacation. She knew that when there, he would be expected to earn his living by working for it. And so indeed it happened. We are told what he did:

"And he (Jacob) abode "immo (with him, Laban) for the space of a month." 42 This is the way the versions put it, the real meanng being that he served him (worked for him) for that time. The next verse proves this. Laban says to Jacob: "Because thou art my nephew (ah) shouldst thou therefore serve me for naught? Tell me, what shall thy wages be?" 43

And when Jacob departed and there was bad blood and chiding between him and Laban, the former remarked: "These twenty years have I been with thee," plainly meaning "These twenty years have I worked for thee." 44

The twenty-fifth chapter of Leviticus, which treats of the sabbatical year and the year of jubilee uses this preposition 'im freely.

We may quote in this connection the already cited sixth verse, which the translators have found troublesome.

The J.P.S. version renders: "And the sabbath-produce of the land shall be food for you: for thee, and for thy servant ('ebed), and for thy maid (amah), and for thy hired servant (sakir), and for 'the settler by thy side' (toshabeka), that 'sojourn with thee' (haggarim 'IмMAK)."

According to our hypothesis the latter part of the sentence really means: "And for thy sakir and for thy toshab that are in thy employ."

Another instance is the provision regarding the fugitive

"1Gen. 29.20. 42Ibid. 29.14. 43Ibid. 29.15. 4Ibid. 31.38. 
slave.45 The J.P.S. version is: "Thou shalt not deliver unto his master a bondman ('ebed) that is escaped from his master unto thee. He shall dwell with thee ('immeka) in the midst of thee, in the place which he shall choose within one of thy gates, where it liketh him best; thou shalt not wrong him (lo tonennu)," the meaning of which is:

Thou shalt not deliver unto his master a bondman ('ebed) that is escaped from his master's service ( $m e^{\prime} i m$ adonaw) unto thee. He shall settle in thy employment ('immeka) in thy midst, in the place which he shall choose within one of thy gates which it liketh him best; thou shalt not wrong him."

Here we see that the slave has escaped from "with his master." That relation is not one of friendly intimacy or of equality. It is the relation of servitude. Nor is the new relation which is to be established for the fugitive any other than one of employment. It also is described by the same preposition ' $i m$.

Moreover there is the significant prohibition lo tonennu, thou shalt not maltreat him, a verb habitually used to describe the ill-treatment of the workman, the ger, which goes far to indicate that the employment of the fugitive slave is contemplated. ${ }^{46}$

Other instances of the use of this preposition ' $i m$ in the sense of being in another's employment are numerous. ${ }^{47}$

There is the story of Micah a rich Ephraimite who had a little temple of his own in which he set up ephod and teraphim and consecrated one of his sons to be the priest (Kohen).

And there came along a Levite, seeking employment. In those early days, there must have been a class of trained

"Deut. 23.16, 17.

48Instances of the use of this verb in connection with the oppression of the ger or other employees are Exod. 22.20; Lev. 19.33; Jer. 22.3; Ezek. 18.12; 22.7, 29.

"Lev. 25.50, 53; Deut. 15.16; Jud. 17.10; 1 Sam. 2.21. 
priests called Levites, who sought employment in their capacity in every one of the tribes.

Micah said to him: "Dwell with me ('immadi). . . and I will give thee ten pieces of silver by the year, and a suit of apparel and thy victuals." (J.P.S. version.) The Levite cheerfully accepted, whereupon Micah installed him and he became Micah's priest, at which Micah greatly rejoiced, believing that the Levite had much more influence with the Lord than his own son would have had, who was after all but an amateur and not a professional priest. ${ }^{4}$

The last example we shall cite of this use of the word ' $i m$ is perhaps the most interesting. It is part of the history of the prophet Samuel.49 The versions agree that the lad "grew before the Lord," the text using the word " $\mathrm{im}$. The true meaning must be that the acolyte Samuel was reared in the service of the Lord.

When we remember that his mother devoted him to the Lord's service when he was a mere babe ${ }^{50}$ and that the child ministered unto the Lord before the priest Eli, ${ }^{5 x}$ we must conclude that the narrative records the lad's progress in the service.

This use in Hebrew of the word ' $i m$ (with) to denote employment, has its analogue in our ordinary English. We have all heard men say, sometimes with evident selfsufficiency, that they are with a great corporation, or a leading mercantile or banking establishment. They do not mean to assert that they are chief or part owners of the business. All they wish us to understand is that they are of its employees.

The third word that contributes to the difficulty is $i m$, the general meaning of which is "if." It may however, on occasion, mean "when." 52

"8Jud. 17.7-13. ${ }^{91}$ Sam. chs. 1-3. 501 Sam. 1.28.

"11 Sam. 2.11, 18; 3.1. B2Brown-Driver, Lexicon, p. 50, sub voce IM b4. 
Having digressed long enough from the main subject in order to elucidate these three words, we may now, in the light of the suggestions put forward, return to our text and seek to make it clearer than the versions have succeeded in doing.

This is the way in which we would explain it:53 "And if a man borrow aught of his rea" (Hebrew employee) and it be hurt or die, the owner thereof not being employed with it, the borrower must make restitution. If the owner thereof be employed with it, the borrower need not make it good. When the man is sakir (that is, hired with his animal to work for a stipulated daily wage), this wage covers everything, the labor of the man, the labor of the animal and the risk of the animal's injury or death while employed in the work under its owner."

The legal reason for the rule if thus established is impeccable. Under the circumstances, when the owner of the animal is himself using it, an injury suffered by it could not with any show of justice be charged to the employer of the man and the beast. It was the duty of the owner to care for his beast. It was under his control and if it was negligently used, the fault is the owner's and not the employer's.

The Mishna seems to understand the law in the same way. In discussing our text it lays down these principles: "If a man borrow a cow and, at the same time or before, hire its owner, and the cow is hurt or dies, the borrower is not liable to pay for the cow, because the Bible says (Exod. 22.14): 'If the owner thereof be with it, he need not make it good." "54 It evidently identifies the owner of the cow with the sakir who has been hired with it or before it, and who works with it.

We have, however, not yet finished with the Toshab.

63Exod. 22.13, 14. $\quad{ }^{54}$ Mishnah, Baba Mesi'a, 8.1. 
He also appears in the expression ger we-toshab and once as ger toshab.

Considerable learning has been expended on the difference between these two forms. As they obviously have the same meaning, the variation need not further concern us.

When Abraham, after the death of his wife Sarah, felt reluctant to bury her in a cemetery over which he would have no control, he applied to the bene-Heth, the natives of the land, and began by saying: I am ger we-toshab with you, 55 meaning that though he considered himself a resident, he recognized the law that, as a ger, he could not be the absolute owner of land. He therefore appealed to them to make an exception under the sad circumstances. Their replies were courteous. They offered him the use of any of their own sepulchres, which would require no infringement of the settled law. He, however, persisted in his request for a sepulchre which would be his absolute property (ahuzzah), and they graciously complied with his request. Needless to say, the lord of the land accepted full payment in silver for the field of Machpelah and the cave that is therein. ${ }^{56}$

That the inability of the ger we-toshab to own land in perpetuity was an accepted doctrine among the Hebrews, appears plainly from the terms of the jubilee law, which required the return in that year, of all purchased land, to its original owner, ${ }^{57}$ the reason stated being that the land itself is God's, and that the human beings who claim its ownership are, as regards Him, merely gerim we-toshabim,,$^{8}$ who, of course, could not be absolute owners.

When the Hebrews are forbidden to hold fellowHebrews as slaves, there is leave granted them to acquire 'ebed or amah from the surrounding nations, ${ }^{59}$ and also

\footnotetext{
65Gen. 23.4. ${ }^{66} \mathrm{Ibid} .23 .5-20 . \quad$ 57Lev. 25.10.
}

orIbid. 25.44 . 
from the toshabim in their employ. ${ }^{60}$ Mention has already been made of the fact that these toshabim may reach a certain degree of prosperity. An interesting linguistic circumstance in that regard is the fact that such a prosperous toshab is spoken of in the same verse as ger we-toshab and as ger toshab. ${ }^{6 x}$

It is time now to return to our simple ger uncomplicated with toshab or sakir.

The presence of a large population in an inferior position but in close relations with Israel would naturally result in a gradual abandonment by them of many prior practices and in a progressive assimilation with the practices of their employers. The absorption of the slave population in the religious community of Israel would be an element tending to hasten such a process.

To determine the course it actually took may be difficult but not quite impossible. The records give us evidence which may be arrayed under the following heads:

A. The gradual admission of the ger to participation in the national religious festivals.

B. Their gradual subjection to laws imposed primarily on Israelites alone.

C. Their presence on occasions of extraordinary solemnity as if they were an integral portion of Israel.

D. The careful provisions made for their gaining and maintaining material advancement.

A. Their position in regard to the festivals:

In the Paschal lamb celebration, the ger were not expected to participate. They were supposed, in general, to maintain their own religious rites and peculiarities, but provision was made that if any one of them desired to join the Israelites in this solemn ceremony, he was at liberty to do so, if he complied with the one condition

60Ibid. 25.45. The words are: "mi-bene ha-toshabim ha-garim Iммакем."

61 Ibid. 25.47 . 
imposed, namely that he and the male members of his family should leave the class of 'arelim and become initiated into the covenant of Abraham. ${ }^{62}$

This was evidently at an early period when it was considered unwise to permit the employer to persuade his ger to adopt Hebrew customs, but the latter was left free to act according to his own desire, without interference of any kind.

And the supplemental ordinance which established for certain emergencies, a Passover of the second month for those who could not lawfully celebrate it in the first month, has the same provision for the ger who wishes to avail himself of it, reference being made to the original Pesah ordinance as the norm. ${ }^{63}$

The festival closely related to that of the Paschal lamb is the Massah festival, (the festival of unleavened bread). ${ }^{64}$ The ordinance establishing it provides that Israelites must eat unleavened bread during seven days and that leaven must be put away out of the houses and "whosoever eateth leavened bread from the first day until the seventh day, that soul shall be cut off from Israel." $6_{5}$ As this like the Paschal lamb celebration commemorated Israel's Exodus from Egypt, it was but natural that the command should be limited to Israel alone. Later on, however, in the same chapter, the ordinance is repeated, but this time three words are added ba-ger $u$-be-ezrah $h a$ ares, which the versions render "whether he be a sojourner or one born in the land." 66 Without stopping to analyze the meaning of this addition, it may be remarked, that in view of the fact that the punishment was excision from Israel, its denunciation against a non-Israelite like the ger would seem strange. The explanation of the apparent inconsistency is to be found in the additional prohibition 
that "seven days there shall be no leaven found in your houses." ${ }_{67}$. This could not be enforced, if there were a group of inhabitants who were at liberty to eat leaven. The ger were not directed or compelled to assume a religious duty of Israel, but they were prevented from interfering with the religious practices of Israel. The Mașsot ordinance therefore viewed the ger, just as did the Passover ordinance, that is, neither considered him as being religiously affiliated with Israel.

Other texts on the subject are to the same effect: "There shall no leavened bread be seen with thee, neither shall there be leaven seen with thee in all thy borders." 68

Affirmation of this view of the ger's position is found in the fact that there was to be a holy convocation and a cessation of servile labor in Israel on the first and the last days of the seven, ${ }^{69}$ but there is no word respecting the ger in this connection. He is not expected to assist in the celebration of the festival. His sole part is to avoid interference with the enforcement of the leaven prohibition.

The ger's religious aloofness is maintained in regard to the Day of Atonement. The ordinance is directed to Israel alone and no one else is included. It is to be a fast day and a rest day; and whosoever breaks the rule against certain forbidden indulgence "shall be cut off from his people," and whosoever works on that day will be destroyed "from among his people."70

Another version of the ordinance ${ }^{7 x}$ presents a variation in that it brings in the ger. After directing like the other, that ye shall afflict your souls and shall do no manner of work, it like the Mașah ordinance has the words: haezrah we-ha-ger ha-gar betokekem which the versions similarly render "whether it be one of your own country or a

67Exod. 12.19. ${ }^{68}$ Ibid. 13.7; Deut. 16.4.

${ }^{\oplus E x o d .12 .16 ; ~ L e v . ~ 23.7, ~ 8 ; ~ N u m . ~ 28.18, ~ 25 ; ~ D e u t . ~ 16.8 . ~}$

70Lev. 23.27-32; Num. 29.7. 71 Ibid. 16.29. 
stranger that sojourneth among you' (King James); 'the home-born or the stranger that sojourneth among you' (J.P.S.). The true bearing and meaning of the added clause will be discussed hereafter. For the present, it is enough to note that the ger must abstain from work not because of any religious obligation resting on him, but rather in order that this day of solemn rest might not be marred by anybody's working.

The New Year's day (Rosh ha-Shanah) ordinance has no reference whatever to the ger. It is to be a solemn rest, a memorial, a holy convocation. No servile work may be done thereon, ${ }^{72}$ but it is for Israel alone and the ger is not called upon to do, or to refrain from doing, anything.

Even the ordinance establishing the weekly Sabbath ${ }^{73}$ with all its anxious care that the ger shall not work on that day, gives no inkling of an approach to a religious fellowship with Israel. It is a day of rest and work therein is forbidden, but the grounds of the prohibition are addressed to Israel alone. They are based on Israel's relation to God and have no hint concerning those who worship other gods. These grounds are: the Lord's resting on the seventh day after the six days of creation ${ }^{74}$ and His leading Israel out of Egyptian bondage. ${ }^{75}$

The $g e r$ is exempted from labor just as are the beasts used in agricultural work: "that thine ox and thine ass may have rest, and thy ben-amah and the ger may be refreshed." 76 The ultimate aim of such a policy was to enforce Sabbath rest on Israelites themselves, which would have been impossible had their heathen workmen been allowed to cultivate their fields and perform other labors. That such enforcement was no easy matter, we learn from the earnest protests of the prophets:

"If thou turn away thy foot because of the Sabbath, 
From pursuing thy business on My holy day;

And call the Sabbath a delight,

And the holy of the Lord honorable,

And shalt honor it, not doing thy wonted ways,

Nor pursuing thy business, nor speaking thereof;

Then shalt thou delight thyself in the Lord." 77

Thus far Isaiah; Jeremiah is equally emphatic. ${ }^{78}$

Indeed, the country people who were pious, construed the Sabbath ordinances in a comfortable way. They evidently believed that their animals though not to be used for agricultural work on the Sabbath, might well carry them on a journey. When the Shunnamite's beloved son died, and she wished to consult Elisha in order that the child might be revived, she called to her husband, who was not informed of the calamity: "Send me, I pray thee, one of the servants and one of the asses, that I may run to the man of God and come back." And he answered: "Wherefore wilt thou go to him to-day? it is neither New Moon nor Sabbath." 79 Had it been such, he would have deemed her request quite proper. Needless to say, she did as she wished.

The command to observe the Feast of Weeks (Shabu'ot) is:

"Seven weeks shalt thou number unto thee; from the time the sickle is first put to the standing corn shalt thou begin to number seven weeks. And thou shalt keep the feast of weeks unto the Lord thy God, after the measure of the free-will offering of thy hand, which thou shalt give, according as the Lord thy God blesseth thee. And thou shalt rejoice before the Lord thy God, thou and thy son and thy daughter and thy man-servant ('ebed) and thy maid-servant (amah) and the Levite that is within thy gates, and the ger and the yatom and the almanah that

\footnotetext{
"7Isa. 58.13, 14. $\quad{ }^{78}$ Jer. 17.21-27. $\quad 72$ Kings 4.23.
} 
are in the midst of thee, in the place which the Lord thy God shall choose to cause His name to dwell there." 80

There is also the provision: "There shall be a holy convocation unto you; ye shall do no manner of servile work." $8 x$

This injunction to refrain from labor does not mention the ger. When, however, the ger is directed "to rejoice before the Lord" in the religious capital of the nation, it is clear that it becomes the employer's duty to travel from his dwelling-place to Jerusalem and to bring with him to this rejoicing before the Lord, not only his own family, but the Levite, the ger, the yatom and the almanah that dwell with him.

This classification of the Levite with a working peasant, which seems strange at first, attests the fact, that at an early time, Levites wandered about the country and obtained employment as paid priests to private persons, as was the case with Micah referred to in the previous lecture. ${ }^{82}$

All of an Israelite's employees are to participate in the ceremonies at Jerusalem, and we have here an advance in the ger's religious position. $\mathrm{He}$ is no longer a mere instrument to assist in enforcing certain religious duties on his employer, but has acquired a distinct status of his own. From a merely negative assistant, he has become a principal.

This advance is maintained in the Sukkot ordinance. ${ }^{83}$ The classes commanded to rejoice at Shabu'ot are likewise to do so in this festival. There is also to be a holy convocation on the first day and a solemn assembly on the eighth. ${ }^{84}$ "Ye shall do no manner of servile work, and ye shall keep a feast unto the Lord seven days." 85

That this advance was but a step forward in the

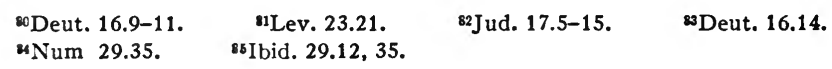


process of the ger's religious assimilation appears from another version of the ordinance which after providing as did those already cited adds the following:

"Ye shall take you on the first day the fruit of goodly trees, branches of palm-trees and boughs of thick trees, and willows of the brook, and ye shall rejoice before the Lord your God, seven days. . . Ye shall dwell in booths seven days; every ezrah in Israel shall dwell in booths; that your generations may know that I made the children of Israel dwell in booths, when I brought them out of the land of Egypt. . ." 86

These special commemorative ceremonies do not include the ger. Another class however, the ezrah in Israel must, like the Israelites themselves, dwell in booths; the ger may not do so. Here, as elsewhere, the versions understand the ezrah to mean the Israelite himself, and the commentators have been much troubled about him. The consideration of his real position must be deferred with the caution, however, that we regard him as being by origin a non-Israelite, though rapidly approaching complete assimilation.

The conclusion is that as regards national religious festivals the ger had advanced towards assimilation but had not gone more than halfway in the process.

B. Besides the ger's part in festivals, his obligation to obey certain laws binding Israelites primarily, was another forward step in his assimilation. There are several instances of this kind.

It was the duty of the Israelite to present his offering at the door of the tent of meeting (ohel mo'ed), failure to do which was punishable by the offender's being "cut off from among his people." 87

This duty was extended to the ger under like penalty

${ }^{86}$ Lev. 23.40, 42, $43 . \quad{ }^{87} \mathrm{Ibid} .17 .3,4,8,9$. 
of being "cut off from his people" meaning Israel. ${ }^{88}$

So likewise was the eating of blood by Israelite or by ger similarly penalized. ${ }^{89}$ The summing up was: "No person (nefesh) among you shall eat blood, neither shall any ger among you eat blood."9o

The bene-Israel were forbidden to give any of their children to make them pass through the fire to Molech.9r As this was an odious pagan custom the penalty of being cut off from among their people ${ }^{92}$ was none too severe.

This prohibition was extended to the ger ${ }^{93}$ under like penalty. Some of them had probably practised this cruel rite. Including them in the prohibition was a measure designed to wean them from odious features of their previous religion and thus constituted a sort of negative proselytism. And this policy was insisted on and emphasized by the additional provision: "Whosoever he be of the children of Israel, or of the ger that live in Israel, that giveth of his seed to Molech must be put to death; the "am ha-ares shall stone him." 94

The penalty first denounced, namely, being "cut off from among their people" has been construed by many as a punishment not to be inflicted by man but by Divine action. Such a penalty would scarcely deter those of the ger who worshipped Molech and looked upon Israel's God as an intruder upon their god's territory, from continuing their cruel rites. The penalty of death to be executed by human hands was likely to be a more powerful motive for abstention.

That the practice was not rare even among Israelites is shown by the hint conveyed in the text, that the tribunal (the 'am ha-ares) would be likely to acquit the offender, just as in our modern experience, jurors who are opposed

88Ibid. 17.9. ${ }^{89}$ Ibid. 17.10. 90 Lev. 17.12. 91 Ibid. 18.21.

92I bid. 18.27. 93Ibid. 18.26. 
to capital punishment refuse to join in verdicts of murder of the first degree punishable by death. ${ }^{95}$

Blaspheming the Name (shem) was a crime almost too horrible to contemplate. The presumption apparently was that God Himself would visit condign punishment on the Israelite guilty of such offence. The code, it is true, has an express prohibition of it to the Israelite but it provides no punishment therefor. ${ }^{96}$

In the course of time the question had to be met.

On a certain occasion the son of an Israelite mother and an Egyptian father blasphemed (wa-yikkob) the Name.97 Divine vengenace did not pursue him and the natural inference was that his exemption was due to the fact that he was not an Israelite. He had however committed a fearful offence for the punishment of which there was no law.

The case was therefore referred to Moses who consulted the Oracle. Whereupon the narrative proceeds:

"And the Lord spoke unto Moses, saying:

"Bring forth him that hath cursed (ha-mekallel) without the camp; and let all that heard him lay their hands upon his head, and let all the Congregation (kol ha-'edah) stone him. ${ }^{98}$ And thou shalt speak unto the children of Israel, saying, whosoever curseth (yekallel) his God shall bear his sin (we-nasa het'o). And he that blasphemeth (nokeb) the Name of the Lord must be put to death; kol $h a$-'edah shall stone him; as well the ger as the ezrah when he blasphemeth the Name, must be put to death."

We have here a specific case for which the authorities could find no established law. Consequently, the supreme judicial authority was invoked with the result that the offender was sentenced to death. This tribunal went a 
step further, and on the basis of this decision as a precedent, laid down a general law applicable to future cases just as precedents in English and American law become in effect statutes for the future.

If, as is not impossible, the Egyptian father in this case belonged to the 'ereb rab, it would indicate that notwithstanding his close association with Israel, and although he had married an Israelite woman, he was still looked upon as in some degree, an outsider. The decision of the tribunal that the ger as well as the ezrah must suffer death for the crime would indicate a marked advance in the ezrah's status, because in this instance, the word doubtless comprehends all Israel.

Whereas, earlier, an Israelite blasphemer of the shem was not subject to human punishment, because it was believed that Heaven itself would punish him, this case established the rule that he was to suffer death on the finding of the proper Court.

Notwithstanding this development, the old popular conception persisted. When Job's wife, exasperated by his tame submission to misfortune, hysterically urged him 'to blaspheme God and die' ${ }^{99}$ she naïvely uttered the common belief that Divine vengeance would promptly follow the offence.

I had hoped to treat in this lecture of all the instances showing the gradual subjection of the ger to laws imposed primarily on Israel, but the time is too short for the purpose and in order not to weary you, we must postpone the rest for the next lecture. 
WE paused at the end of the last lecture at the consideration of one of the series of laws laid down for Israel, but which were gradually, in whole or in part, applied to the ger.

It remains to treat of the rest of that series. Before doing so however we cannot ignore the fact that we will over and over again meet with the EZRAH, who, we have already hinted, was not of Hebrew origin.

At a very early stage of Hebrew history, we find the law that the alien ger, if he complies with a certain condition "shall be as the ezrah ha-areș."

It is necessary to know what the status of this ezrah ha-ares was, if we would measure the ger's progress in the Commonwealth. The versions generally agree that he was the Israelite himself. In the Pesah ordinance just cited, they render ger by stranger and ezrah ha-ares, by "one that is born in the land," evidently meaning Palestine. As the ordinance is stated to have been handed down in Egypt, it is difficult to see how they could have adopted such an expression, since, up to that time, not an Israelite of them all had been born in Palestine. The difficulty is not new. It has been encountered before and our endeavors must be directed to obtain as satisfactory a solution as possible. There are two forms of the term: ezrah ha-areș and ezrah. Ezrah ha-ares occurs but three times, while ezrah is found thirteen times. Of these thirteen 
instances, there are four, which are followed by added words, that may be termed explanatory. Once we have ezrah mi-kem (the ezrah among you), twice we have ezrah bi-bene Yisrael (the ezrah among the children of Israel) and the fourth time we have ezrah be-Yisrael (the ezrah in Israel).

The versions (A.V. and J.P.S.) agree in rendering ezrah ha-areș by born in the land. In their translations of the four instances in which ezrah is followed by a qualification they agree in the rendering home-born.

For the nine instances in which the ezrah stands by itself, the King James version has seven variant renderings: homeborn, once; one of your own country, three times; one of your own nation, once; born in the land, once; born of the country, once; born among the children of Israel, once; born among them, once. The English and American Revisions and the J.P.S. version agree in uniformly rendering the word by home-born in all these nine instances.

The great probability is that ezrah ha-ares is the original form and that ezrah is merely a convenient abbreviation.

It is therefore specially important to fathom the origin of this ezrah ha-ares.

One noticeable feature is that the three instances in which it occurs are all connected with the celebration of the Exodus-the Pesah-mașsah festival.

The historical setting of the narrative is that this festival was ordained on the day that Israel was to start on its journeying from the land of Egypt, ${ }^{2}$ and that Israel did not go alone but was attended by a considerable group of non-Israelites, a group which must have been composed of Egyptians, whose discontent with conditions in their native land, impelled them to seek a way out, and who therefore resolved to become proselytes and to stake

2Exod. 12.39, 51. 
their fortunes on the future achievements of Israel. This accession to their numbers was probably looked upon as an advantage by the leaders of Israel. By the mass of the people it must have been viewed coldly if not with positive aversion. Otherwise the fact would be inexplicable, that this reinforcement is mentioned in the texts by two names, expressive of contempt: 'ereb $r a b^{3}$ and asafsuf,4 both of which might fairly be rendered "the rabble." That so important an adjunct should have no other designation than these nicknames is barely conceivable. When it is remembered that, according to the narrative, Israel, though bound for foreign parts, had not yet left Egyptian territory, what more likely than the thought of calling these non-Hebrew Egyptians, natives of the land (Egypt)

- (ezrah ha-ares)? The only land they had yet touched was Egypt, in which they considered themselves outsiders, strangers, (gerim $)^{5}$ and there could be no plainer contradistinction than between foreigners and natives (gerim and ezrah ha-ares). Moreover that so considerable a body of men should after the Exodus be spoken of but once and then in contemptuous terms is, to say the least, strange. What became of them?

The one occasion on which they are referred to, is full of interest. At an early stage of their journey, the Israelites came to think its hardships unendurable, and practically revolted against the Lord and against Moses. There is fair ground for believing that the brother and the sister of Moses, Aaron and Miriam, instigated the rebellion, being jealous of the predominance of their eminent brother. ${ }^{6}$ However that may be, the movement was pretty general among the people.

When it collapsed, the crowd realized that it had blundered, and with the usual unfairness of crowds, sought

${ }^{3}$ Exod. 12.38. $\quad$ 'Num. 11.4.

'Exod. 22.20; 23.9; Lev. 19.34; Deut. 10.19; 23.8. ONum. 12.1-5. 
a scape-goat to cast the blame upon. The Egyptian group, being a minority, were, of course, fastened upon, and the asafsuf were charged with having incited and misled the people. ${ }^{7}$ As has been said asafsuf was only a nickname. The versions treat it as equivalent to 'ereb rab, on the theory that they were the original 'ereb rab or their progeny. Rashi makes the same identification and so is the general opinion. The important implication of the narrative is that the asafsuf were of sufficient numbers and importance to sway the multitude in a movement of transcendent significance. And yet we never hear of them again.

Just as they unaccountably disappear, so do the ezrah ha-ares unaccountably appear. We are not told whither the former went, nor whence the latter came. That they must have been a group of recognized importance is plain from the fact that the ger are under certain conditions to attain a position equal to that of the ezrah ha-ares.

The common notion that they are the Israelites themselves must have originated from the circumstance that in fifteen of the sixteen passages in which they are mentioned, they are placed in collocation with the ger and that hence it was concluded that they were in contradistinction to the ger; and if this were so, the inference was easy that the ezrah was Israel.

To this theory, plausible as it seems, there are objections weighty, if not insurmountable.

There is the sixteenth instance, in which the ezrah is in no relation whatever with the ger because the latter is not even mentioned.

In the Sukkot ordinance of Leviticus ${ }^{8}$ there is a command addressed to Israel in these words: "Ye shall dwell in booths seven days," and, the verse goes on, "all the ezrah in Israel shall dwell in booths," and the next verse

'Num. 11.4. BLev. 23.42. 
explains the purpose: "that your generations may know that I made the children of Israel to dwell in booths when I brought them out of the land of Egypt. . . ."9 Here the collocation is with Israel alone, and in order to identify the two, it must be assumed that the second half of the verse is a useless repetition of the first, and even if this were granted, we should still have to learn why in the second half, the whole body of Israel should be spoken of as being "in Israel," an expression which clearly implies a distinction of some kind between Israel and ezrah.

Doubtless this Sukkot ordinance originated in the very beginning of the nation. Hosea in the eighth century B.C. alludes to the custom of dwelling in Sukkot as having subsisted in hoar antiquity: "I will again make thee to dwell in tents, as in the days of the Mo'ed." "ro By mo'ed he means the festival of Sukkot. II In the Deuteronomic version of the Sukkot ordinance there is not a word about dwelling in booths. The custom was so rooted in the habits of the people, that no mention of it was necessary. In reciting the participants in the rejoicing before the Lord on that festival, there is nothing said of the ezrah who had doubtless been so completely assimilated that he is included in the "thou" addressed to the people of Israel. "Thy God" is his. They had become one. ${ }^{\mathrm{I2}}$

The implied distinction between Israel and ezrah in the Sukkot ordinance does not stand alone. There are three other passages which carry a similar implication. One of them speaks of the ezrah mikkem (the ezrah among you), ${ }^{13}$ while the other two tell us of the ezrah bi-bene Yisrael (the ezrah among the children of Israel). ${ }^{14}$

We cannot, in the face of such evidence, escape the conclusion that the ezrah was originally a numerous body

Ibid. 23.43. $\quad{ }^{10}$ Hosea 12.10.

"Brown-Driver, Lexicon, p. 417, sub voce Mo'ed 1b; Deut. 31.10.

${ }^{12}$ Deut. 16.13-17. ${ }^{13}$ Lev. 19.34. ${ }^{14 N u m .15 .29 ;}$; Ezek. 47.22. 
which finally entered into the composition of Israel, and that to render the word by Israel or its equivalent, in every text in which it occurs, will create error and confusion. There was a time when the ezrah became fully assimilated, and at this point the difficulty presents itself. While the ezrah before such complete assimilation was not identical with Israel, there was a great change after that event, and then the ezrah was sometimes included in the term Israel, and at other times the whole of Israel was designated by the term ezrah.

As the two kinds of ezrah are externally similar, it is not easy to determine which ezrah is in any particular case meant. The main factor in the decision must be the context-an appreciation of the circumstances and a common-sense conclusion therefrom.

The result of such an examination presents some curious features. Of the four cases in which the ezrah is accompanied by a qualifying phrase, there is one in which that phrase is probably due to a scribe's error.

The latter half of the fifteenth chapter of Numbers provides for the atonement of sins committed in error (shegagah), and declares that, the proper ceremonies being performed, "all the congregation of the children of Israel shall be forgiven, and the GER that liveth among them; for, in respect of all the people ( $\mathrm{kol} \mathrm{ha-'am)}$ it was done in error." 15

The plain meaning of this is that the people of Israel (the 'Am) are composed of two elements, the bene Israel and the ger. Of the division of the bene Israel into component parts there is not a hint. And yet in the same connection, a few verses further on, it is provided that the priest shall make atonement for "the ezrah among the children of Israel, and the ger that liveth among them: ye 
shall have one law for him that doeth aught in error." ${ }_{16}$

And continuing the theme, atonement is denied to him that sinneth with a high hand, whether he be ezrah or ger. ${ }^{17}$

There can be no question that the ezrah all through this half chapter is identical with Israel, and the conclusion follows that the added words "among the children of Israel" in the 29th verse are out of place and should be elided.

The three passages which use the expression ezrah ha-ares may fairly be counted as not referring to Israel. There is a special insistence that the Pesah shall be celebrated "by all the congregation of Israel" ${ }_{18}$ and the institution is of so early a date and the expression ezrah ha-ares is at that stage so inept to describe Israel, that doubt on the subject may be dismissed.

There is however one circumstance which must be noted. The whole chapter mentions the ezrah ha-ares twice and while still dwelling on the same subject, once introduces simple ezrah. ${ }^{19}$ This can only mean the ezrah ha-ares and cannot therefore be interpreted to mean Israel.

This leaves nine passages in which ezrah may fairly be said to stand for Israel. An examination of the context confirms this view of its meaning.

These are the passages:

Lev. 16.29, relating to the Day of Atonement.

17.15 , relating to the prohibition against eating nebelah (that which dieth of itself).

18.26 , relating to the observance of certain moral duties.

24.26 , relating to the punishment of blasphemy. 24.22, establishing uniformity of law for ger and ezrah.

10Num. 15.29. ${ }^{17}$ Ibid. 15.30. ${ }^{18 E x o d . ~ 12.47 . ~} 19$ Ibid. 12.49. 
Num. 15.13, relating to meal offerings.

15.29-30, relating to sins committed in error (shegagah).

Josh. 8.33, describing Joshua's audience.

The result so far seems to be that the earliest mention is that in the Sukkot ordinance, in which the ger is not yet thought of, and in which the ezrah is viewed as distinct from the body of Israel. Ye (addressing Israel) are commanded to dwell in booths, to which there is the significant addition that "all the ezrah in Israel shall dwell in booths." This points to a time when the ezrah had reached the stage of believing himself to be an essential part of all Israel, but had not succeeded in convincing the bulk of Israel of that fact. The ezrah, at this mo'ed period might logically urge that he had accompanied Israel on its travels and had to dwell in booths like the rest. Why then should he be excluded from the celebration of that experience? At all events any effort at such exclusion was ineffective, made so by the specific ordinance not only allowing but commanding him to dwell in booths at the Mo ed.

When we meet him next he is far advanced on the road towards assimilation but has not finally reached the goal. There is no longer a question about his right to celebrate the Pesah. That is assumed ${ }^{20}$ and though there are a few later instances in which the distinction between him and the Israelite is recognized, yet this soon ceases. The word ezrah is not even mentioned by any of the prophets from Amos down save only by Ezekiel in one text and his use of it is merely literary and oratorical. It refers to no one in being but is a vision of a finer future based on past history. ${ }^{2 \mathrm{I}}$

The change in the meaning of the word was in conformity to the general law that mutations in the life of 
the body are reflected in the career of the words designating it.

The mode here adopted is not new. The investigators of ancient times encountered the same difficulties and one of them, at least, treated them in a manner somewhat analogous.

About eighteen hundred years ago, the Syriac Targum (called the Peshitta) understood ezrah to mean Israel in eight of the sixteen passages. It can scarcely be a mere co-incidence that seven of these belong to the list of nine Israels given by us; the eighth (Num. 15.29) counted by us is excluded by the Peshitta. It is however not rendered by any other word, but is passed over evidently on the theory that its presence is due to an error in the text, while our ninth (Josh. 8.33) may well give rise to two opinions, though on the whole we prefer the rendering Israel.

The Peshitta's eighth Israel is Lev. 19.34. This is one of the four passages from which we infer that the ezrah were originally a separate, non-Israelite group. The Peshitta shies at such an inference but nevertheless is unable to find Israel in the other three and therefore practically elides the word from them. In this instance, however, the terrifying qualification in Israel, or among the children of Israel is lacking. Instead of an objectionable noun there is only a pronoun, mi-kem (among you) and it is encouraged to render the ezrah among you as Israel. Needless to say in such reasoning we cannot concur. If the Peshitta were right its translation would read, "the Ezrah (Israel) among you (Israel). . ."

The other eight passages which the Peshitta did not render by Israel it treats in three ways. In four it rendered by the equivalent of yosheb ha-ares (dweller in the land), in one by 'Amora, and in the remaining three it ignored the word and translated the sentence as if the word were not there. 
While we may not agree with the Peshitta's procedure, its outstanding feature is the recognition of the fact that in half the instances of its use, the word ezrah does not mean Israel and it is therefore in advance of most moderns who seem to have sensed no difficulty in uniformly understanding it to refer to Israel.

Let us, however, examine in detail, the Peshitta's treatment of these eight non-Israelite passages.

It renders yosheb ha-areș four times. Probably the rendering was intended to parallel the Hebrew ezrah haares. The latter expression occurs only thrice in the texts and of these three it translates one by 'Amora.. It renders simple ezrah by yosheb ha-areș in two cases, one in Exodus 12.49 which we have above concluded stands for ezrah ha-ares and the other in Joshua 8.33 where, as we have above stated, a difference of opinion may well exist.

What the Peshitta exactly means by yosheb ha-ares is a matter that deserves careful examination. I have roughly conceived it to mean the conquered Canaanites, whom we in this investigation, have settled upon as the ger of the texts. If this supposition is justified, it would follow that the Peshitta's ger is not an important compact body like ours, but is composed of alien individuals who, from time to time, leave their former surroundings and become converts to Israel's religion.

There is, however, a clue to the Peshitta's meaning. In Number 9.14 it renders ezrah ha-areș not by yosheb ha-ares but by 'Amora. The definition of 'Amora is given as follows:

"Workman. In Syria the workman is called Amora." 22 As the Peshitta uses "Amora as the equivalent of yosheb ha-ares, it seems fair to infer that it views the conquered

${ }^{22}$ Neuhebräisches und Chaldäisches Wörterbuch by Prof. Dr. Jacob Levy, vol. 3, p. 665 . 
Canaanites as a body of laborers, just as we have done, but calls them ezrah instead of ger. And this ezrah it seems to look upon as a body completely assimilated to Israel at the earliest period of the nation's history. In short it knows no real distinction between "the congregation of Israel" and the ezrah ha-ares of the Passover ordinance. The ger of that ordinance is for it, a casual stranger who has imbibed the notion that he would like to become a convert to Israel's religion.

The three passages in which the Peshitta refused to translate the word ezrah must have given the Targumist infinite trouble. He knew his plain duty to be to transfer the original text to its Syriac equivalent. In the Passover ordinance he had gone so far as to recognize the ezrah's incorporation in the body of Israel and in these three passages he was met by expressions which differentiated between ezrah and Israel. The notion that circumstances and therefore laws might have changed, in short that the Hebrew nation like others had been subject to the law of development, was to him not only inadmissible but impossible. For him the Canaanites-the ezrah - when conquered, immediately became attached to Israel's law and religion, and were indistinguishable from the main body.

Instead of solving the difficulty he evaded it, and, curiously enough, in doing so he practically adopted the favorite modern method of dealing with obstacles in the text of the Bible-namely, textual criticism. He may not have been fully conscious of the audacity of his procedure, but he none the less corrected the text by practically striking out the disagreeable words that bothered him.

Notwithstanding the impossibility of agreeing to all of his views, it has been a source of gratification to find 
this early scholar reach conclusions with which, in the main, I agree.

In modern times too there have been dissents from the current notion that ezrah always means Israel.

Professor Reggio, of the Rabbinical College of Padua, Italy, makes the following remarks on the subject:

I have explained to you the meaning of ger toshab and ger ședek. I now come to ezrah. This term is applied to all those who live in a country in which they have been born and in which their forefathers have been settled, no matter to what people or religion they belong. In this sense it is the opposite to ger. A clear proof of this explanation is the fact that the term is used for trees and plants which still stand on the ground on which they have grown (see Psalm 37. 35). Similarly Kimhi in his Dictionary says that the ezrah is the old inhabitant of a city. Accordingly I believe that the Canaanites who remained in Palestine after the conquest of the land were called ezrahim. Wessely's statement (on Leviticus 16. 29) that ezrah only refers to Israelites, as many rabbinical statements also seem to imply, sounds very strange to me, since many verses do not bear this interpretation (see e.g. Numbers 9.14). After the Israelites came to Canaan the people were compelled to accept the seven Noahidic commandments and then were considered on the same level with ger toshab, the only difference being that they had remained in the country. If they were fully converted they would be on a plane with the ger sedek. ${ }^{23}$

Needless to say I do not concur with much that Reggio says in this note, but consider it important to cite him because, great scholar as he was, he could not accept the general rendering of our word ezrah.

For all of the facts concerning the Peshitta, I am

${ }^{23}$ Iggerol Yashar (Vienna, 1834-6), vol 1, pages 52-53, Letter 8. 
indebted to that great authority on the Syriac Targum, the Reverend Doctor Chayim Heller, who, learning of the work in which I was engaged, generously sent me a memorandum on the subject of which I have made free use. Needless to say that the Reverend Doctor is not responsible for the opinions and conclusions derived by me from the facts.

We are now ready to resume the main line of our discourse, and to examine the remaining instances of laws primarily intended for Hebrews and subsequently imposed upon the ger.

Immediately following the blasphemy statute with the consideration of which we ended the last lecture there is laid down a little code as follows:

He that smiteth any man mortally shall be put to death.

He that smiteth a beast mortally, shall make it good, life for life.

If a man maim his fellow ('amito); as he hath done, so shall it be done to him: breach for breach, eye for eye, tooth for tooth; as he hath maimed a man, so shall it be rendered unto him.

He that killeth a beast shall make it good.

He that killeth a man must be put to death.

Ye shall have one manner of law as well for the ger as for the ezrah. ${ }^{24}$

One may fairly ask why should such a monstrous crime as murder be denounced for ezrah (meaning Israel) and for ger when the general law governing Israel had made it a capital crime in terms that could not be misunderstood. A possible explanation may be that in the early times, the ger had certain community privileges, among them the right of judicial cognizance of crimes committed by 
their own members among themselves, and that the enactment in question contemplated the ger's assimilation to the Hebrew community and abolished such separate jurisdiction, so that like the Israelites themselves, the ger would be answerable to Israel's judicial tribunals-an enormous step in the advance towards equality.

In this little code the punishment for maiming was according to the law of retaliation.

In view of the fact that the general principle of Israelite law in case of personal injuries was otherwise, a question arises as to the reason for this seeming conflict of laws. The Israelite law regulating the punishment for personal injury was the payment of adequate money damages for the loss of the victim's time and for the cost of healing. ${ }^{25}$ And this law was general, for it contemplated not only injuries inflicted with the fist, in the heat of passion, in a quarrel, but also injuries caused by a dangerous weapon, a stone, the use of which implies malice aforethought.

The provision that demands payment of the cost of healing implies that the injury is not permanent.

The maiming of this Levitical code evidently refers to an injury which cannot be healed, such as the loss of an eye or another member of the human body. Such an injury is technically termed mum. Then there is the probability that among the crude peasantry of Canaan, the infliction of such permanent injuries was often the purpose of the fighters, and severe measures were deemed necessary to overcome such a habit. It may be remarked, in passing, that even in modern times, there were places among the civilized nations, in which the gouging out of an adversary's eye was deemed to be fair fighting. In this connection a quotation from Webster's Unabridged (sub voce "Gouge") may not be out of place:

${ }^{25}$ Exod. 21.18, 19 
"Gouge-To force out, as the eye of a person, with the thumb or finger (U.S.).

The practice of gouging is said to have existed formerly in the interior of some of the Southern states, but was never known elsewhere, except by hearsay (Bartlett).

Gouging is performed by twisting the forefinger in a lock of hair, near the temple, and turning the eye out of the socket with the thumb nail, which is suffered to grow long for that purpose (Lambert)."

This little code so far as it provides for the punishment of homicide must be read with the Numbers statute which makes malice aforethought the indispensable ground for convicting a man of the capital offence of murder, ${ }^{26}$ and thereby abolishes the lex talionis to that extent. If malice is absent, the homicide is reduced from murder to manslaughter and the punishment from death to internment in a separated city frequently called "city of refuge" ('ir miklat). This 'ir miklat statute is expressly declared to be "for the bene Yisrael, for the ger and for the toshab in their midst, ${ }^{27}$ or as it is put in the Joshua text: "for kol bene Yisrael and for the ger who lives in their midst." ${ }_{28}$

The next instance of the class we are considering is the following:

Moses, at a particular period, was directed to speak to the children of Israel concerning certain duties which would devolve upon them after their settlement in Canaan. One of these duties referred to meal-offerings and drinkofferings and they are prescribed in adequate details.

${ }^{26}$ Num. 35.22-29. See my Ancient Hebrew Law of Homicide (Philadelphia, 1915).

${ }^{27}$ Num. 35.15. The distinction in this verse between $g e r$ and toshab is the only instance of the kind in Scripture. That there is some error or confusion in the text seems obvious. It is probable that the scribe's ms. read "for the toshab" and as the sakir was equally entitled to the benefit of the statute, he probably wrote in the margin "for the ger" in order to note that both toshab and sakir were included, and this gloss probably crept into the text.

The Joshua text is perfectly clear. It declares the separated cities to be for $k o l$ bene Yisrael and for the ger. The toshab is not mentioned.

${ }^{28}$ Josh. 20.9. 
Thereupon there is this additional provision:

"Every ezrah shall do these things after this manner. . . and the ger or whoever may be among you throughout your generations and will offer an offering made by fire. . . as you do, so shall he do."

"As for the congregation (Kahal) there shall be one (and the same) statute for you and for the ger, a statute forever throughout your generations; as ye are, so shall the ger be before the Lord. One law and one ordinance shall be for you and for the ger living with you." ${ }_{29}$ Here the ezrah stands for Israel. The principle therein declared, though limited to this particular religious activity was couched in terms to make a profound impression on the general public, who, according to the custom of homogeneous communities, looked upon any, new element introduced as inferior.

There were certain peculiarities in the wording of this addition which are worthy of attention. Its first word is ha-Kahal which J.P.S. renders: "As for the congregation." That this is not a satisfactory rendering needs no remark. Its great fault is that it conveys no idea. The probability is that it was a scribe's marginal note which has crept into the text and this seems to be the view of Bertholet. ${ }^{30}$

How the scribe came to write such a note may be plausibly explained. The word Kahal in reference to Israel, in the numerous instances in which it occurs, always means Israel alone without the infusion of any others. ${ }^{3 x}$ Indeed the distinction between Kahal and ger is expressly declared when we are told that "there was not a word of

${ }^{29}$ Num. 15.2, 13-16.

${ }^{30}$ Bertholet, Die Stellung der Israeliten und der Juden $z$ u den Fremden, p. 170, note 2.

${ }^{31}$ Exod. 12.6; 16.3; Lev. 4.13, 14, 21; Num. 10.7; 14.5; 16.3, 33; 17.12; 19.20; $20.4,6,10,12 ; 22.4$; Deut. $9.10 ; 10.4 ; 18.16 ; 23.2,3,4,9 ; 33.4 ; 1$ Kings $8.14,22 ; 12.3$; Jer. 26.17; Micah 2.5; 1 Chron. 13.2, 4; 28.8; 29.1, 10, 20; 2 Chron. 1.3, 5; 6.3, 12.13; $20.5 ; 23.3 ; 24.6 ; 28.14 ; 29.23,28,31,32 ; 30.17,23,24,25$. 
all that Moses commanded, which Joshua read not before kol-kehal Yisrael and the women and the little ones and the ger that walked among them." ${ }^{2}$

So also in the narrative of Hezekiah's great Pesah festival it is recorded that "kol-kehal Yehudah, and the priests, and the Levites, and kol-ha-kahal that came out of Israel, and the gerim that came out of the land of Israel and that dwelt in Judah rejoiced." 33

The scribe who was copying our ordinance which declared itself to be one statute for you (Israel) and for the ger that liveth with you, which further declared that "as ye are, so shall the ger be before the Lord," and which emphasized these declarations by adding that "there shall be one and the same Torah and mishpat for you and for the ger living with you" might well exclaim: Behold, the ger has become incorporated into the Kahal! We have now an enlarged Kahal!

We may readily affirm his view and conclude that this ordinance contemplated the religious assimilation of the ger with Israel.

At this point we may note that ger is not mentioned in Ezra-Nehemiah, Ruth, Proverbs, Ecclesiastes, Song of Songs, Lamentations, Daniel and Esther, a significant. indication that the distinction between him and the whole community of Israel, had, after the Return from Babylon, been ignored and forgotten.

The next ordinance to be considered is the statute providing for the atonement of the community or of the individual for certain violations of law committed by error or inadvertence (shegagah). If the fault be that of the congregation ('edah) a specific sin-offering is required, whereupon the priest makes atonement for the whole congregation of the bene Israel "and they shall be for-

32Josh. 8.35. $\quad{ }^{33} 2$ Chron. 30.25. 
given." 34 This effect is repeated in the next verse with an important addition thus: "And all the congregation of the children of Israel shall be forgiven and the ger living in their midst; it was the error of kol ha-'am (the whole people)." 35

If the fault be that of an individual, the offering to be brought by him is specified, and the priest shall make atonement for him and he shall be forgiven. "The ezrah among the children of Israel and the ger that liveth in their midst; there shall be one law (Torah) for him that doeth aught in error." ${ }_{36}$

Just as in the previous ordinance the ger is considered to be part of the Kahal, so in this he is viewed as part of the ' $A m$. And the Bene Israel and the ezrah are used interchangeably. They seem to fix the period at which the ger became fully assimilated, civilly and religiously.

There is, too, a statute which provides for purification from defilement by the dead. We may call this the statute of the Red Heifer. A whole chapter is devoted to it. ${ }^{37}$ It was without doubt originally binding on Israelites only, but in the tenth verse the words "and unto the ger dwelling in their midst" follow the word "Israel," that being the only mention of the ger in the whole chapter. There could be no more intimate fusion of ger and Israelite than in such an ordinance looking to perfect ritual purity.

We may here pause a moment to consider an ordinance which belongs to an early period when the assimilation of the ger was not yet in sight. The carcass of an animal which died of itself (nebelah) was held to be unfit for the food of Israelites. It was an abominable thing..$^{3}$ Nevertheless, as in other times and climes there were those who violated the prohibition. Jeremiah denounces such sinners. ${ }^{39}$ Notwithstanding the aversion with which the

$\begin{array}{lrr}{ }^{34} \text { Num. } 15.25 . & { }^{35} \text { Ibid. } 15.26 . & { }^{36} \text { Ibid. } 15.29 .\end{array}$


idea of an Israelite's eating such a thing was viewed, express permission was granted to give it to the ger to eat, presumably as part of his food-wage. $4^{\circ}$

As the assimilation of the ger progressed there was a supplemental ordinance which reads thus: "Every person (nefesh) that eateth nebelah or terefah, among ezrah or among ger shall wash his clothes and bathe himself in water and be unclean until the even; then shall he be clean. But if he wash them not, nor bathe his flesh, then he shall bear his iniquity." 4

Here we have the extremes of the assimilation progress of the ger. At first he is treated as a complete outsider religiously, while in the last instance, he is regarded as an intimate proselyte, who, if he fail to conform to the requirements, "must bear his iniquity," that is, must expect direct Divine punishment. ${ }^{42}$

The tithe of the third year is another instance showing the relation between the land-owner and the ger. This tithe must be specially set aside for the Levite, the ger, the yatom and the almanah, to whom it shall be for food. ${ }^{43}$

This provision is usually construed as a charitable gift to the poor. It is more probably a supplemental compensation for laborers in the land-owner's employ. We have in a previous lecture alluded to the fact that Levites were in the early days hired for wages to perform certain religious duties. Nothing is more likely than this: that we have here a list of several species of workers, who were entitled to these third-year tithes as a bonus, to use the language of our contemporaries.

This ordinance seems devoid of any religious signifi-

0 Deut. 14.21.

4Lev. 17.15, 16. The expression "bear his iniquity," as has been suggested in the preceding Lecture, conveys Divine punishment for an offence committed by an Israelite. Here the ezrah (meaning the Israelite) and the ger are put in the same class in this regard.

42Exod. 28.43; Num. 18.22. 43Deut. 14.28, 29; 26.12, 13. 
cance as regards the ger. He need not do anything nor refrain from doing anything. It is a civil matter, a regulation of the relations between employer and employees.

C. Besides the classes of cases of which we have hitherto treated, there is a third class which shows that on certain occasions of extraordinary solemnity in Israel, the ger were invited to be, and were, present as if they were an integral portion of the community.

When the end of Moses' life was near, he called a meeting of "all Israel" 44 and exhorted them to observe the words of the covenant and do them. 45 In oratorical style he addresses them by classes, "even all the men of Israel, your little ones, your wives and thy ger that are in the midst of thy camp from the hewer of thy wood unto the drawer of thy water; that thou shouldst enter into the covenant of the Lord thy God . . " "which the Lord thy God maketh with thee this day." ${ }_{46}$ "Neither with you only do I make this covenant and this oath, but with him that standeth here with us this day. . . "47

In his portrayal of the consequences that will follow Israel's non-observance of the law, Moses is still more emphatic in his recognition of the ger as an integral portion of the body of Israel. These are his words: "The ger asher be-kirbeka shall mount above thee higher and higher; and thou shalt come down lower and lower. He shall lend to thee and thou shalt not lend to him; he shall be the head and thou shalt be the tail." ${ }_{48}$ Just as we describe the individual body by saying "from head to foot," so he in portraying the corporate body uses the words "from head to tail." In both cases the thought is that the body may be characterized by its two extremes.

Again, Moses in his final charge to "the priests the sons of Levi" and to all the elders (zekenim) of Israel ${ }^{49}$

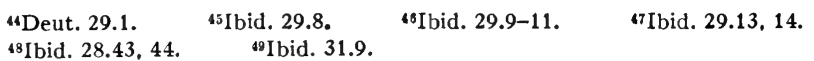


directs them to read the Law once in every seven years, at the feast of Tabernacles "before all Israel in their hearing." so And thereupon he defines what he means by "all Israel."

"The men and the women and the little ones and thy ger that are within thy gates, that they may hear, and that they may learn, and fear the Lord your God, and OBSERVE TO DO all the words of this law, and that their children, who have not known, may hear, and learn to fear the Lord your God. . ." 5 I

And finally it is recorded that Joshua, in compliance with the direction of Moses "wrote there (in Mount Ebal) upon the stones a copy of the law of Moses. . . And all Israel and their elders and officers, and their judges, stood on this side the ark and on that side . . . as well the ger as the ezrah. . . " ${ }_{52}$

In a great chapter of the Holiness Code, fundamental moral laws for the governance of Israel are laid down, the violation of which was declared to have resulted in the downfall of the vanquished Canaanites and Moses summed it all up by saying: "Ye therefore shall keep My statutes and Mine ordinances and shall not do any of these abominations-the ezrah and the ger that live in your midst." ${ }_{53}$ Here again, ezrah means Israel. It will be seen that the ger are no longer looked upon as strangers, but as fully accepted proselytes, forming a recognized portion of the Israelite religious community.

Ezekiel seems to look upon them in the same light. ${ }^{54}$

D. We are finally to consider the provisions made for the improvement of the ger's material condition and the consequent intellectual and spiritual advantage accruing to him.

Perhaps the most important improvement in the ger's

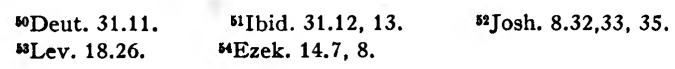


material condition was produced by granting him rest from labor on the weekly Sabbath.

The tradition was uniform that this institution was of the greatest antiquity. The accepted belief that God himself rested on that day from the work of Creation attests this. Moreover when Israel's support in the wilderness was by manna which fell from Heaven, two portions fell on Friday in order to relieve the people from the work of gathering it on the seventh day. ${ }^{55}$ Of the various texts commanding the observance of the Sabbath, only three contain any reference to the $g e r .{ }^{56}$ The others are addressed to Israel alone. ${ }^{57}$

And these three disclose peculiarities which merit attention. The first of them ${ }^{58}$ addressed to Israel commands that on the seventh day "thou shalt not do any manner of work," with which the sentence might well have ended, but it goes on "thou, nor thy son, nor thy daughter, nor thy man-servant ("ebed) nor thy maid-servant (amah) nor thy cattle, nor thy ger that is within thy gates." That the mention of the slaves should be followed by the cattle may well give the impression that the sentence is finished, when, lo and behold! after the cattle come the free employees as if by an afterthought of later times.

The second of them ${ }^{59}$ is likewise addressed to Israel and commands "On the seventh day thou shalt rest that thine ox and thine ass may have rest." After this care for the animals, there follows the additional ground "and the son of thy handmaid (ben-amah) and the ger may be refreshed."

The family are not mentioned, probably on the presumption that by the use of the second person the landowner addressed would assume that his family was included.

BExod. 16.22,23. BEIbid. 20.8-11; 23.12; Deut. 5.14.

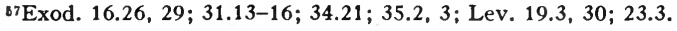

B8Exod. 20.10. $\quad 59$ Ibid. 23.12. 
The third of them ${ }^{60}$ has the same list as the first to wit: thou, thy son, thy daughter, thy man-servant ('ebed), thy maid-servant (amah), and then follow the ox, the ass, or any of the cattle. Only after these comes the ger. The most curious feature of this text is, however, what follows the ger, namely the purpose of this ordinance which is declared to be that "the "ebed and the amah may rest as well as thou." Not a word about the ger, just as if the sentence had been finished before he was introduced or thought of.

It is not an unreasonable inference that these three texts were originally addressed to Israel alone, and that the anxious care for the workman, slave and free, 'ebed and ger was developed in the course of Israel's history.

To return now to our Sabbath-law prohibiting work by the ger on that day. It should be remarked that though the benefit of it was primarily material, in that it gave the workman a substantial interval of rest, thereby relieving the monotony, the dulness and the fatigue incident to unceasing physical labor of one sort, yet the advantage to the laborer in another aspect was even greater. The leisure afforded by the regularly recurring period of rest at short intervals, made it not only possible but inevitable that he should observe and to a certain degree imitate the habits and practices of his master's family and the result would follow that he would cultivate thoughts which in his previous condition would have been beyond his reach.

The command to the ger to abstain from work on Atonement day was another long step in advance. ${ }^{6 r}$ The extraordinary solemnity surrounding its celebration stimulated reflection in a high degree. He saw his master deprived not only of food but of other ordinary indulgences

"Deut. 5.14. "1Lev. 16.29; Num. 29.7. 
which seemed not only necessary but indispensable. There were moreover stately ceremonies conducted by the priests, which were well adapted to rouse curiosity and interest. ${ }^{62}$

So too the Day of Memorial (now called Rosh haShanah ${ }^{63}$ ), the day of the blowing of the horn (the Shofar), could well rouse emotions and implant ideas concerning a man's being and his future.

Less grave than these solemn occasions was the PesahMașsot festival. While the Hebrews called the Mașsot (unleavened bread), the bread of affliction, ${ }^{64}$ the fact that the festival celebrated the rise of the nation gave it a joyful color which mere nicknames could not overcome. While the ger was free to join in the Pesah ceremonies, he was also free to refrain. The choice was his. ${ }^{65}$ During the Mașsot festival, however, he was bound to abstain from eating leaven ${ }^{6}$ and the probability is that so far from being conscious of any affliction he enjoyed it, while drinking in from his surroundings historical memories in which it is true he had no part, but which nevertheless tended to raise his intellect to a higher plane. When a mere yokel loses sight for a time of the insistent present and dwells even with bare superficiality on a past replete with great deeds, he imbibes ideas which spiritualize his whole being.

Hebrew life though essentially solemn was not monotonously so. There was a joyous side and the ger reaped the full benefit of it.

At the gathering of the first fruits of the wheat harvest there was a great holiday, ${ }^{67}$ the feast of weeks (Shabu'ot). Naturally there were impressive ceremonies $^{68}$ but these were coupled with the injunction to go up to the religious capital with the family, the slaves, the Levite and the ger, yatom (fatherless) and almanah (widow) and there rejoice

${ }^{\circ 2}$ Lev. 16.32-34; 23.27-32. ${ }^{63}$ I bid. 23.24; Num. 29.1.

ssExod. 12.48. or Ibid. 34.22 .
${ }^{64}$ Deut. 16.3. 68Lev. 23.16-21. 
before the Lord thy God. ${ }^{69}$ And this rejoicing was not to be merely rhetorical or spiritual. There were to be feasts: "Thou shalt eat there." 70 And the practice conformed to the ordinance. ${ }^{7 x}$

And the "Feast of Ingathering at the end of the year, when thou gatherest in thy labors out of the field" 72 partook of this same frolicsome nature. This is the Festival known as Sukkot (Tabernacles), ${ }^{73}$ one of the most jovial features of which was, doubtless, a great army of paraders bearing branches of palm-trees, willows of the brook and other plants. Even if the ger were not admitted to join in the procession, they doubtless enjoyed looking at it, as we know from the habits of people of our own time. Needless to say there were abundant ceremonies besides. ${ }^{74}$ Here too all the householder's dependents, his family, his slaves, the Levite, the ger, the yatom and the almanah asher bi-she'areka were to "be altogether joyful." 75

In order to complete this branch of our inquiry, it will be necessary to cite the general principles laid down for the treatment of the ger as well as the special regulations made in his behalf. The most important of these practically was the protection of the ger in his right to adequate wages or other compensation.

"A ger thou shalt not wrong, neither shalt thou oppress him." 76 In view of the relations of the ger with his employer, the wrong and the oppression here spoken of can mean nothing else than exacting an undue amount of work or whittling down the compensation for it so as to render it inadequate.

The farmer may not go back to recover a sheaf forgotten in the harvest. It is for the ger, the yatom and the almanah nor is he allowed to go again over the boughs of

${ }^{80}$ Deut. 16.11. 72Exod. 23.16. 75Deut. 16.15.

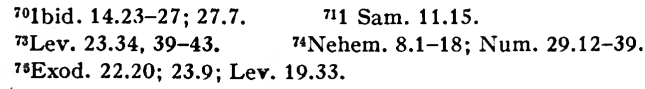


the olive-trees. What is left also goes to the ger, the yatom and the almanah, and the like disposition is made with respect to the gleaning of the vineyard. ${ }^{77}$

In the parallel passages of Leviticus, the provision is that the corner of the field must not be reaped, nor the gleaning of the harvest or the vineyard gathered. They belong to the 'ani and the ger. ${ }^{78}$

In still another Levitical passage only the corner of the field and the gleaning of the harvest are mentioned and these are to be for the "ani and the ger. ${ }^{79}$

We have here three kinds of disposition of the farmer's remainders after the collection of his produce. The first specifies in more detail the several species to be distributed and awards them to ger, yatom and almanah, the second omits the olive-trees but names the other species, while the third omits not only the olive-trees but the vineyard. Then too the first names as beneficiaries the ger, the yatom and the almanah while the second and third omit the yatom and the almanah but add the 'ani.

These variations lead to the inference that at the time of the first ordinance, the order of Hebrew workmen called 'ani had not yet been regarded as a class by themselves; but that the bulk of the agricultural work was done by the non-Hebrew classes to wit, the ger, the yatom and the almanah, that these being settled on the land indefinitely, were not paid wages, but received their support in kind which was supplemented at harvest time by what their employers doubtless called a gratuity in the nature of the bonus so anxiously looked for by the workmen of our own day.

The inference from the second and third ordinances is that the ger therein named was used as a general term to include the yatom and the almanah of a deceased ger,

${ }^{77}$ Deut. 24.19,20, 21 . $\quad 78$ Lev. 19.9, $10 . \quad{ }^{79} \mathrm{Ibid}$. 23.22. 
which words were therefore omitted, while the Hebrew workmen, the 'ani had so increased as to form a class by themselves who were admitted to share in the bonus.

The wages of a sakir shall not abide with thee all night until the morning. ${ }^{80}$

The product of the seventh or fallow year shall be for food of the land-owner and of all his dependents including his sakir and his toshab. ${ }^{81}$ Moses, in his charge to the judges enjoins upon them to judge righteously between a man and his ger. The great probability is that the questions arising between these two classes referred to quantum of labor or of compensation. ${ }^{82}$

At the end of every three years the land-owner was ordered to lay up the tithe of his increase and this belonged to the Levite, the ger, the fatherless and the widow, all, in one sense or another, employees of the owner. ${ }^{83}$

The prophets, Jeremiah, ${ }^{84}$ Ezekiel, $^{85}$ and Malachi, ${ }^{86}$ especially the latter, were insistent upon obedience to these requirements. The general principles, illustrative of these regulations were emphatic.

The leading one was enunciated in several specific cases:

When the punishment for various offences was laid down, the pronouncement with which the little code concluded was:

"One mishpat shall be for you, as well for the ger as for the ezrah. ${ }^{87}$

When the Pesah of the second month was instituted the doctrine was repeated in words nearly similar. ${ }^{88}$

And the like occurred in respect to offerings ${ }^{89}$ and to the atonement for sins of inadvertence.90

The persistent repetition of this declaration undoubt-

80Lev. 19.13; Deut. 24.14, 15.

88 Ibid. 14.28, 29; 26.12, 13.

${ }^{86}$ Mal. 3.5.

oIbid. 15.29.

\footnotetext{
MLev. 25.6.

MJer. 7.6; 22.3.

${ }^{88}$ Num. 9.14.

${ }^{82}$ Deut. $1.16 ; 24.17 ; 27.19$.

85Ezek. 22.7, 29.

${ }^{80}$ Ibid. 15.16.
}

87Lev. 24.22. 
edly gave it the effect of a principle generally applicable. The fact that it failed of universal effect is attested by the speeches of the prophets. This, however, need not surprise us. Ancient men were much like moderns. In their day as in ours, natives looked upon themselves as superior to men of other nations, and even in their most liberal moods, exhibited as against them, a certain condescension. This trait too was heightened and exaggerated then as now when the others were inferior in prosperity and social standing.

These mighty efforts to produce unity between Israel and the ger were further strengthened by such declarations as these:

"Thou shalt love him (the ger) as thyself; for ye were gerim in the land of Egypt."9r

"He (the Lord) loveth the ger in giving him food and raiment. Love ye therefore the ger; for ye were gerim in the land of Egypt."92 The effort was to remind the superior that in his origin, he was as humble as the class he wished to look down upon.

While naturally the object was not fully attained, there was undoubtedly created a higher and purer sentiment regarding the relation between Hebrew employer and non-Hebrew employed.

We have now reached a point where we shall feel at liberty to assume that the ger were a large population of Palestinian natives who, by the conquest, lost their lands and became employees in the service of the conqueror.

We shall next proceed to ascertain whether there were other classes of non-Hebrew laborers; and this brings us back to our starting-point, the classification of ger with yatom and almanah (fatherless and widow) which we shall proceed to consider in the next Lecture.

'Lev. 19.34. $\quad$ 92Deut. 10.18, 19. 
THE frequent collocation of ger with yatom and almanah started our whole inquiry. The accepted notion that they were classed together because they all needed the kindliness and charity of the public seemed inadequate.

The result of the inquiry so far has been that we have collected evidence enough to establish the fact that the ger were a large class, that they were the conquered inhabitants of Palestine, and that the majority of them had remained on the land as feudal employees of the conquerors. That these so settled were called toshabim, gertoshab, or ger we-toshab. That the minority not so settled became sekirim or wage-earners. To speak of a large population of industrious laborers as objects of charity is merely absurd.

Then what is the meaning of the collocation of ger, yatom and almanah? If their being classed together gives them certain leading characteristics in common, it would seem that the ger's leading characteristic, to wit, being a laborer, might inhere also in the yatom and the almanah, however fantastic such a view might at first appear.

In every instance where the locution is used, it is quite consistent with such a view, especially when we consider that the peasant gerim were landless and were dependent on their compensation for the support of their families. When such a ger died, what was to become of his widow and children? The interest of the land-owner would be to oust them from their cottage and to put in their place a strong man capable to do what the decedent had done. 
The humanitarian policy of the state would have been defeated if the land-owner had been allowed to consult his pecuniary interest only. The best that could be done was to leave the family in their place and set them to work doing as much as possible. This was probably a fair proportion of what had been done before, since doubtless the ger had been assisted in his work by his wife and such of his children as were old enough to help. The case of Ruth shows that the practice of women to work in the field was well established. Boaz, in addressing her, said: "Go not to glean in another field, but abide here fast by my maidens. Let thine eyes be on the field that they do reap, and go thou after them."'

And that children would be compelled to work appears plainly from Job's bitter speech against the avaricious rich, however exaggerated its terms. ${ }^{2}$

Our ger, yatom and almanah are coupled together in at least sixteen instances which may be divided into five classes. Six of them refer to the oppression of laborers by their employers, five speak of their participation in the fruits of the soil, two of their joinder with other employees in great celebrations by their masters, two enjoin on the judges the duty of disregarding differences of status among litigants and commanding them to do justice to laborers and the sixteenth is a Divine fiat announcing that Heaven itself takes special care of yatom, almanah and ger.

I. The first class of six are these:

a) "The ger thou shalt not wrong (lo toneh) nor oppress him (lo tilhașennu). . . Kol almanah we-yatom ye shall not afflict (lo te'annun)."'3

1Ruth 2.8, 9. 2 Job 24.3-12. 'Exod. 22.20, 21. 
b) Jeremiah speaking at the gate of the Temple says: "Do justice between a man and his rea" (the versions render: neighbor, but the meaning here is his Hebrew employee); do not oppress (lo ta'ashoku) ger, yatom and almanah."4

c) Jeremiah, under instruction, addresses the King in these words:

"Execute ye justice and righteousness, and deliver the spoiled (gazul, robbed) out of the hand of the oppressor ('ashok), and do no wrong (al-tonu), do no violence (al tahmosu) to the ger, yatom and almanah."s

d) Ezekiel, inveighing against the princes (nesiim) of Israel charges them with grave crimes, among them these: "They have dealt by oppression ('asu be'oshek) with the ger; they have wronged (honu) yatom and almanah." 6

e) Zechariah, harping on the same subject says: "Do not oppress (al ta'ashoku) the almanah and yatom, the ger and the "ani."'

f) And finally Malachi closes the prophetic era by denouncing "those that oppress ('oshekim) the sakir in his wages, the almanah and the yatom and turn aside the ger from his right (matte ger)."8

In these six passages denouncing oppression five words are used. Their basic forms are: 'ashak in five of the texts, honah in three, and 'innah, lahas, and hamas each in one. They all signify the ill-treatment of one by another, oppression. There might be room for speculation as to what kind of oppression may be referred to. Fortunately, the Malachi text solves the problem, by the specific statement that the 'oshek, the oppressor, is wronging the employee, the sakir in respect to his wages. The inference

'Jer. 7.5, 6. JJer. 22.3. $\quad$ 'Ezek. 22.7. TZech. 7.10. 
is obvious that the other classes mentioned with the sakir are fellow-employees and that in that relation they are the victims of ill-treatment by their employers.

The dictionaries lay especial stress on the idea of extortion involved in 'ashak,' or as the Hebrew with brutal frankness calls it "robbery" (gazul) and on the idea of ill-treatment of the poor and weak involved in honah, ${ }^{10}$ and these are the two words running through all these passages.

Oppression as between employer and employee would likely be of two kinds, overworking and under-payment. Needless to say, a cruel master might be guilty in both respects. In the case of the sakir there might be an additional mode of oppression. He was the only laborer who was to be paid a daily wage at sundown. The law is imperative: "The wages of a sakir shall not abide with thee all night until the morning." shalt give him his hire, neither shall the sun go down upon it." ${ }^{12}$ An avaricious master would violate this law, just as selfish and inconsiderate men violate other laws.

II. Next to this series of six passages are five, in which the ger, yatom and almanah are made to participate in the fruits of the soil ${ }^{13}$ and following these five are:

III. Two passages which represent the ger, the yatom and the almanah as enjoying, with other employees, great national and religious celebrations, all under the charge of their employers. ${ }^{14}$

The seven passages of these two series have been sufficiently considered in the previous Lecture and need not be repeated here.

IV. We have, next, the two passages which enjoin the duty of disregarding differences of status among men. They are these: 
"Thou shalt not pervert the justice due to the ger, yatom (mishpat ger yatom) nor take the almanah's raiment to pledge."15

"Cursed be he that perverteth the justice due to geryatom we-almanah. . ." 16

and finally we have this passage:

V. " $\mathrm{He}$ (the Lord) doth execute justice ('oseh mishpat)

for the yatom and the almanah and loveth the ger in giving him food and raiment." ${ }^{17}$

An attentive consideration of these sixteen passages discloses a certain historical order showing the stages at which the various classes of laborers among the Hebrews were formed.

At first, that is, as soon as the natives had been subjected to the loss of their land and the bulk of them had become a settled peasantry under their new masters, the texts are confined to the ger, yatom and almanah alone without thought of any other class. There was urgent need for their protection and there were prompt measures to secure it for them.

These texts are found in four verses only. In the verse which represents God as speaking for justice and love to them no other class is mentioned. This is the text which has just been cited at length. ${ }^{18}$

One of the texts which provides for a supplemental compensation in addition to the ordinary reward given to working-people is composed of three verses: the first of them directs that a forgotten sheaf may not be gone after by the farmer but must be left for the ger, yatom and almanah, ${ }^{19}$ the second imposes on the farmer the same duty of abstention after beating his olive-trees and reserves what remains thereon for the ger, yatom and almanah, ${ }^{20}$

\footnotetext{
${ }^{15}$ Deut. 24.17. $\quad$ 18Ibid. 27.19. $\quad$ 17Ibid. 10.18. $\quad{ }^{18}$ Ibid. 10.18.

19Ibid. 24.19. 20Ibid. 24.20.
} 
while the third has an analogous provision in the gleaning of the vineyard. ${ }^{21}$

Though these are three separate verses in each of which the same beneficiaries of the farmer's abstention are named, they are in reality but one ordinance, inculcating one duty, namely, the duty of giving to the laborers whose active work contributes greatly to the increase of the produce, an extra gratuity which has a tendency to cheer and exalt them.

The result reached from a consideration of all the passages may fairly be said to be that the yatom and the almanah when mentioned as pendents to the ger, are not Israelites, but are the ger's (the non-Hebrew's) widow and children, who after the father's death were allowed to remain where they had always been, on condition of course that they should become employees in his stead. This conclusion however does not negative the idea that there are texts which speak of the yatom and almanah of Hebrews.

When the Hebrew widow had no child, the death of her husband practically threw her back on her father or his family. ${ }^{22}$ If, however, she had a child, the husband's land descended and the widow and children remained on it as before. The gebul almanah ${ }^{23}$ is referred to as well as the prohibition against trespassing on the fields of the yatom. ${ }^{24}$ So too the avaricious men are described by Job as being alert to drive away the ass of the yetomim and to take the almanah's ox for a pledge. ${ }^{25}$ With a fundamental law which aimed at equality of land-ownership by individuals, the invasion of the neighbor's land by crossing the boundary line (gebul) or by obliterating it so as to seize a portion of the neighbor's land was a heinous offence: "Thou shalt not remove thy neighbor's land-mark ( $\mathrm{gebul})$ " ${ }_{26}$ is a stern prohibition which is drastically strengthened by

\footnotetext{
${ }^{21}$ Deut. 24.21. $\quad$ 22Lev. 22.13. $\quad$ 23Prov. 15.25. $\quad 24$ Ibid. 23.10.

${ }^{25} \mathrm{Job} 24.3$.
} 
the Arur-code: "Cursed be he that removeth his neighbor's (gebul) land-mark." ${ }_{27}$ Hosea, denouncing the princes of Judah, finds nothing more degrading to characterize them than likening them to those "that remove the landmark." ${ }_{28}$ Proverbs too repeats the accepted view: "Remove not the ancient land-mark which thy fathers have set." ${ }_{29}$

The Hebrew yatom and almanah were therefore not objects of charity in general. They did need protection, however, against the greed of wily land-grabbers who were ever ready to take advantage of the helplessness not only of unsophisticated persons suddenly thrust into a position of responsibility without adequate preparation, but of those land-owners whose management of their farms was not efficient enough to assure their ability to hold them permanently. Doubtless the current philosophy and morality of the avaricious was satisfactory to their class as it has been from that day to this: The fittest survive. Whoso fails should abandon the task and serve others who can do better, and so on and so on.

The prophets did not see eye to eye with them. Amos thunders against them: "They sell the innocent for silver and the ebyon for a pair of shoes. They pant after the dust of the earth on the head of the dallim and pervert the right of the humble ('anawim)." ${ }_{30}$ Isaiah, somewhat later (8th century B.C.), is specific in his denunciation of their efforts to gain a monopoly of the land:

"Woe unto them that join house to house,

That lay field to field,

Till there be no room, and ye be made to dwell

Alone in the midst of the land!" ${ }^{3}$

and Micah (724 B.c. and later) does the same.

"Woe to them that devise iniquity

And work evil upon their beds:

${ }^{27}$ Deut. 27.17. $\quad{ }^{28}$ Hosea 5.10. $\quad{ }^{20}$ Prov. 22.20. $\quad{ }^{80} \mathrm{Amos} 2.7 . \quad{ }^{31}$ Isa. 5.8. 
When the morning is light, they execute it,

Because it is in the power of their hand.

And they covet fields, and grab them; (gazalu)

And houses, and take them away;

They oppress a man and his house (family)

Even a man and his heritage (nahalah)." ${ }_{32}$

After the provisions for securing the ger, yatom and almanah there is another stage which introduces alongside of them a new class of beneficiaries, namely the Levite class. This disposition is made in three verses, the first of them providing that the tithe of the third year, shall be disposed of as subsidiary compensation to "the Levite, the ger, the yatom and the almanah that are within thy gates" (asher bi-she'areka), ${ }^{33}$ the second of them directing that the rejoicing on the Feast of Weeks at the national sanctuary thereafter to be established, shall be by the employer and his family, by his slaves, by "the Levite that is within thy gates" and by "the ger, the yatom and the almanah that are in the midst of thee" (asher be-kirbeka), ${ }^{34}$ and the third of them laying down a similar rule for the celebration of the Tabernacle festival the beneficiaries of which are to be the same as those named for the Feast of Weeks, namely, the employer and his family, his slaves "and the Levite, the ger, the yatom and the almanah that are within thy gates." 35

We have in a previous lecture referred to the case of the Ephraimite Micah who employed a Levite of the mishpahah of Judah to be his $a b$ and his kohen promising to pay him for this service ten pieces of silver by the year and a suit of apparel and his victuals. And on these terms the bargain was concluded. The narrative is of great antiquity. Though the facts as told were shocking to the sensibilities of the compiler, he recited them fully.

${ }^{32}$ Micah 2.1, 2. $\quad{ }^{33}$ Deut. 14.29. $\quad{ }^{34}$ Ibid. 16.11. $\quad{ }^{35}$ Ibid. 16.14. 
The chapter in which the narrative occurs is well worth reading. ${ }^{36}$

It shows why the Levites like the ger, the yatom and the almanah are located bish'areka or be-kirbeka (within thy gates or in thy circle). They are all resident on the estate of the owner in whose employ they are. A widespread notion that these words refer to residence in Israel at large, is clearly inept. They point directly to the land of an individual and relate to persons under his control.

When a central sanctuary was established, perhaps at Shiloh, a new governmental policy was instituted. The sanctuaries on private estates were to be discontinued. They were an obstacle to the unity of the state and moreover tended to perpetuate pagan practices.

The measure designed to abolish them was the institution of a system of pilgrimages to the central sanctuary. There were to be three of these pilgrimages in every year, one on Pesah, the next on Shabu'ot and last and greatest of all, the one on Sukkot. ${ }^{37}$ Though the ordinances commanding these pilgrimages were doubtless observed, the result was not what had been hoped for. When the owners of the private sanctuaries with their retainers returned home, many of them adhered to their ancient customs and consulted their Levites as of yore.

To overcome this, inducements were offered to the Levites coming from these estates to remain at the central sanctuary, which movement, if successful, would finally cause the local sanctuaries to wither away and in the end perish from inanition.

The ordinance on this subject was well adapted to effect the purpose. It is as follows:

"And if (when) a Levite come from any of thy gates

${ }^{26} \mathrm{Jud}$. chap. 17.

${ }^{37}$ Exod. 23.14-17; 34.23; Deut. 16.16; 1 Kings 8.2, 65; 2 Kings 23.23; Neh. 8.18; 2 Chron. 7.8, 9. 
(me-ahad she'areka) out of all Israel, where he lives (gar sham), and come with all the desire of his soul unto the place which the Lord shall choose; then he shall minister in the name of the Lord his God, as all his brethren the Levites do, who stand there before the Lord. They shall have like portions to eat, beside that which is his due according to the fathers' houses" ("al ha-abot). ${ }^{38}$ This is the J.P.S. version. A. V. renders the last phrase "that which cometh of the sale of his patrimony," and this translation is adhered to by the English and American Revisions.

That all these renderings are inadequate seems clear. What the ordinance really meant was, that the local Levites who would remain at the central sanctuary, were allowed to do so without abandoning their local position and emoluments. Many would have dreaded the change, if it involved the loss of what they had, because of the fear that their position at the central sanctuary would be uncertain, and that if they should be deprived of it, they would be turned loose upon the country and be compelled to wander round in order to obtain proper places.

Hence, the provision that they should retain what they had at home namely "that which belonged to the abot," the latter word meaning the country Levites themselves. It will be remembered that Micah employed his Levite as kohen and as $a b .{ }^{39}$

We may now close the discussion concerning the ger, yatom and almanah, in the belief that their position as laborers of non-Hebrew origin has been sufficiently established.

It behooves us now to inquire concerning the existence of Hebrew labor-classes.

Our information on this point is derivable from observing the texts relating to ger, yatom and almanah in order

${ }^{28}$ Deut. $18.6,7,8 . \quad{ }^{30}$ Jud. 17.10. 
to learn whether, associated with these, there are other classes of persons who are laborers like themselves, and if there are such, whether they differ from the ger in that they are of pure Hebrew blood. The sixteen instances which speak of the ger, yatom and almanah are, as has been said, divisible into five classes:

Of the first class referring to oppression of ger, yatom and almanah by their employers there are six, and five of these are connected with other terms denoting classes of persons in the same category as themselves, to wit, free laborers.

Following the order just adopted we find that the first of the six texts, Exodus 22.20, 21, associates the following classes:

The 'ani 'immak (which I would render, the 'ani in thy employ), ${ }^{40}$ thy $\mathrm{rea}^{6},{ }^{41}$ the $d a l^{42}$ and the ebyon. ${ }^{43}$ The second of these six texts, Jeremiah 7.6, is accompanied by the rea'. ${ }^{44}$

The third of them, Jeremiah 22.3, is associated with the $r^{\prime} a^{45}$ and with the 'ani we-ebyon. ${ }^{46}$

The fourth of them, Ezekiel 22.7, is followed by the rea ${ }^{6} 7$ and by the 'ani we-ebyon ${ }^{48}$ while,

The fifth of them, Zechariah 7.10, utters ger, yatom, almanah and 'ani in one breath.

The sixth, Malachi 3.5, adds none of these terms, but introduces the sakir in the same sentence with the ger, yatom and almanah.

These terms for persons in a position similar to the ger, yatom and almanah are not fanciful superfluities. They denote a substantial distinction, which is, that the ' $a n i$, the rea', the dal and the ebyon are Hebrews, while the others are the native Canaanites and their progeny,

\footnotetext{
40Exod. 22.24.

4Jer. 7.5 .

1I Ibid. 22.25.

4 Ibid. 22.13.

42Ibid. 23.3; 30.15 .

6 Ibid. 22.17.

sIbid. 23.6, 11.

48 Ibid. 22.29.
} 
who have become laborers for their Hebrew conquerors. There are some valuable hints favoring this conclusion scattered through the texts, e.g.: If thou lend money to any of $M y$ people even to the 'ani 'immak, ${ }^{49}$ thy brother, thy 'ani, thy ebyon; ;0 $^{50}$ the ebyonim of thy people; ; $^{5 \mathrm{x}}$ an ebyon, one of thy brethren $;^{52}$ thy brother, the ebyon. ${ }^{53}$

"Thou shalt not respect the person of the dal, nor favor the person of the mighty; but in righteousness shalt thou judge thy fellow" ('amiteka) ("amit wherever it occurs refers to a fellow-Israelite). ${ }^{54}$

The dallim of the ' $\mathrm{Am}$ (referring to Israelites). ${ }^{55}$

As regards the rea' there can be no doubt the word is in direct contrast with ger which refers to the nonIsraelite. Its use for Israelite is exemplified in the following: "Thou shalt not go up and down as a tale-bearer among thy people, neither shalt thou stand idly by the blood of thy rea'. . . Thou shalt not hate thy brother in thy heart; thou shalt surely rebuke thy 'amit. . . Thou shalt not take vengeance, nor bear grudge against the children of thy people, but thou shalt love thy rea' as thyself. . ." 56

Note that later on in the same chapter, there is exactly the same wording with reference to the ger: Thou shalt love him as thyself. 57

The sakir whom Malachi mentions in addition to the ger, yatom and almanah had a rather complicated history. At first he was a mere sub-division of the ger; later on a class of Hebrew sekirim arose and the ger sakir and the Hebrew sakir existed side by side. ${ }^{8}$ Probably by Malachi's time (he was about 300 years later than Amos) the distinction between the two classes had become obliterated and all the sekirim were regarded as of genuine Hebrew stock.

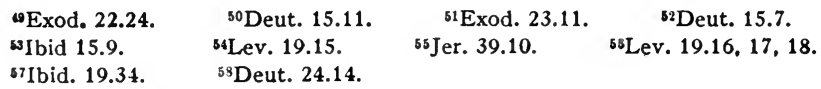


It is, of course, unnecessary to remind you that the special meaning of laborers here attributed to all these words is not generally accepted. The general meaning of 'ani, according to the Dictionary is "poor, afflicted, humble"; that of ebyon: "in want, needy, poor;" that of dal: "the poor" and that of rea": "friend, companion, fellow." 59

The disparity need not surprise us. We have but to remember that in pretty nearly every language, English not excepted, the great mass of people who are not rich, but who work for a living are curtly called "the poor". ${ }^{60}$

Indeed Murray illustrates his definition by quoting from Burke who denounces as base and wicked, the canting phrases of demagogues about "the laboring poor." One might almost suspect the great orator of speaking under the inspiration of the philosophy of our Book of Proverbs, which dubs the arrogant upstart, who dwells in fancied superiority over his fellow-men, "the scorner" $(l e s)^{63}$ and, much to his disadvantage, contrasts him with his betters, the humble men, the laborers ('aniyyim). "The Lord scorneth the scorners (leșim) but giveth grace unto the 'aniyyim." 62

"The rich man ('ashir) is wise in his own eyes;

But the poor (dal) that hath understanding searcheth him through." ${ }_{3}$

A comparison of the texts relating to "the poor" will show that they have no reference to mere paupers, but that they deal with substantial citizens whose labors contribute to the general welfare.

Mere paupers are essentially different. They are free of obligations. They own nothing, they owe nothing, and are creditors to no man. It follows that they have

B Brown-Driver, pp. 2, 195, 776, 945.

"Webster's Unabridged, p. 1012; Murray's (The Oxford) English Dictionary, vol. 7. pp. 1114, 1115.

"Prov. 21.24. 
no occasion to sue and no man thinks of suing them. The whole machinery of civil justice is to them a mere spectacle. As to being victims of extortion or of oppression the thing is impossible. The worst that can befall them is to be refused a gratuity. Beyond that they cannot be victimized.

The texts that we are considering deal with quite another kind of persons. Though not rich they are possessed of some property, they can borrow money, they can sue and be sued and they are liable to pay public taxes.

The Book of Exodus contains seven texts which bear upon this subject.

The first, which has been commented on in an earlier lecture of this series, relates to the rea' from whom an animal is hired, sometimes to be worked by its owner, and sometimes by the borrower or by another in his behalf. ${ }^{64}$

The second refers to the "ani: "If thou lend money to any of my people, to the 'ani 'immak, (the 'ani in thy employ) thou shalt not be to him as a creditor, neither shall ye lay upon him interest." 65

The third refers once more to the rea': "If thou take thy rea"s garment to pledge, thou shalt restore it unto him by that the sun goeth down; for that is his only covering, it is his garment for his skin; wherein shall he sleep?" 66

The fourth refers to the $d a l$ : "Thou shalt not follow the multitude to do evil; . . neither shalt thou favor the $d a l$ in his cause", while the fifth refers to the ebyon:

"Thou shalt not divert justice (mishpat) from thy ebyon in his cause." 67

The sixth also refers to the ebyon: The produce of the fallow year shall be for "the ebyonim of thy people" to eat, ${ }^{68}$ while

The seventh recurs to the $d a l$. It provides for a census-

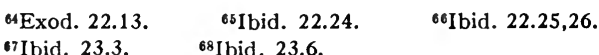

'Ibid. 23.3. $\quad{ }^{68}$ Ibid. 23.6. 
tax. Everyone numbered shall pay half a shekel: "The rich (he-'ashir) shall not give more, and the poor (ha-dal) shall not give less. . . . " 69

This group of Exodus texts is of interest in various aspects. It and the Jeremiah group of analogous texts are the only ones which employ all of the four terms rea', 'ani, dal and ebyon.

What however is more important is the fact that all the members of all the classes mentioned have either some property or some credit. The rea' is represented in one text as the owner of an animal which he hires out for money, and in another he borrows money, pledging his garment for its repayment. He is probably always poor, but sometimes very poor and seems like the sakir to depend on his daily wage for his living. The ordinance requires that this pledged garment shall be handed to him at night so that he may have a covering needed for sleep. Such a loan must therefore finally rest on credit, that is, the lender must believe that the borrower, once having his garment, will not refuse to work to pay off the debt.

The 'ani, in one text, is represented as being credited with a loan without a pledge, the creditor apparently believing, not only that he will pay the debt, but will also pay interest thereon. The ordinance, however, interferes with such a contract by declaring the exaction of such interest illegal.

This subject of interest for money loaned or tarbit (increase) for victuals loaned was an important feature of labor conditions in the ancient world. The wages or other compensation must have been so scanty that whenever anything beyond the ordinary occurred in a laborer's family, he was compelled to resort to a loan to tide it over, and for this loan interest or increase was exacted. No 
one but the employer would lend the money to these laborers and there was practically no opportunity to earn a surplus wherewith to pay it back. On the contrary, as new difficulties arose there would have to be more loans. When it is remembered that the great Babylonian empire's normal rate of interest was three times as great as ours, it will be seen with what terrific rapidity a loan would be doubled. The natural effect of such conditions was that the poor laborer would have to work all his life in the vain effort to reduce a debt which was steadily mounting. $\mathrm{He}$ would in short be in a position barely distinguishable from slavery.

That the ger were at first in this condition is fairly inferable from the words of Moses in describing the evil consequences which the non-observance of the Lord's law by Israel would entail: "The ger that is in thy midst. . shall lend to thee and thou shalt not lend to him."70 With the rise of Hebrew working-classes, the latter became subject to the same practices, and the problem of curing the evil became insistent.

The result was the ordinance which forbade the charging of interest for loans to the 'ani $i^{\text {i }}$ and afterwards to any Israelite who had become impoverished ${ }^{72}$ and finally to the sweeping prohibition to take interest from any one but a nokri, an unmitigated alien, a foreigner. ${ }^{73}$ The effect of this was far-reaching for it relieved the ger, who had by that time either reached assimilation or approached it. While this consequence is nowhere stated directly, it is implied in the ordinance which forbade the charging of interest to an impoverished Israelite who must be treated as a ger we-toshab and no interest or increase may be asked of him. ${ }^{74}$

This, however, was not the limit of its accomplish-

$\begin{array}{ll}\text { "0Deut. 28.43, } 44 . & \text { "Exod. 22.24. } \\ \text { "Deut. 23.20, 21. } & \text { "Lev. 25.35-37. }\end{array}$ 
ment. It practically acted as an obstacle to the development of commerce, evidently on the matured policy of favoring and stimulating agricultural activity. Trade and commerce were to be left to the nokri, meaning, most probably, the Phoenicians, the Tyrians. Isaiah speaks of Tyre as destined "to have commerce with all the kingdoms of the world" 75 and Ezekiel addresses it as "the merchant of peoples for many isles" ${ }^{76}$ while Proverbs and Job both use the word kena'ani (Canaanite) for "merchant." 77

However discouraging this state-policy of the Hebrews was to mercantile adventure, it was steadily adhered to. "Take no interest from an Israelite" was the slogan. Like all forcible prohibitive measures there were those who violated it. Ezekiel is especially bitter on such, holding them to be criminals of the deepest dye. ${ }^{78}$ While his denunciation may have been intensified by ultra-enthusiasm for the cause, it nevertheless reflected general opinion. A man entitled to respect, one "who shall sojourn in thy tabernacle" is he "that putteth not out his money on interest."79 The wisdom of Proverbs is equally condemnatory: "He that augmenteth his substance by interest and increase, gathereth it for him that is gracious to the dallim." 80

We must not however permit our attention to stray too long from the texts concerning the Hebrew workingman which we were considering when we lighted upon the subject of interest on loans.

And now to resume:

The $d a l$ is spoken of in one text as liable to a fixed capitation tax, like any other citizen rich or poor, which necessarily involves the idea of his having or claiming to have a valuable interest of some kind worth striving for.

The ebyon too is in one text viewed as having such a

$\begin{array}{lcc}\text { 78Isa. 23.17. } & \text { 7Ezek. 27.3. } & \text { "Prov. 31.24; Job 40.30. } \\ \text { 78Ezek. 18.13. } & \text { 70Psalm 15.5. } & \text { 20Prov. 28.8. }\end{array}$


case at law. In the other case he is made to receive a quantum at least of the produce of the fallow year. The questions raised in this instance are complicated. First, we must understand what the fallow year is.

The first provision respecting it is as follows:

"Six years thou shalt sow thy land, and gather in the increase thereof; but the seventh year thou shalt let it rest and lie fallow and the ebyone 'ammeka shall eat and what they leave the beast of the field shall eat. In like manner thou shalt deal with thy vineyard and with thy oliveyard." $8 x$

This curt paragraph cannot possibly be the whole law on a subject so intricate and so important. It would seem to have behind it a body of traditional or oral law familiar to all, and to be stated as it is, merely to introduce a new feature to be added to the old common law.

There is, however, another provision, which being more extended, throws light upon the whole subject. It is found in Leviticus. "When ye come into the land which I give you, then shall the land keep a Sabbath unto the Lord. Six years thou shalt sow thy field, and six years thou shalt prune thy vineyard, and gather in the produce thereof. But in the seventh year shall be a Sabbath of solemn rest (Shabbat Shabbaton) for the land, a Sabbath unto the Lord; thou shalt neither sow thy field, nor prune thy vineyard. That which groweth of itself of thy harvest thou shalt not reap, and the grapes of thy undressed vine thou shalt not gather; it shall be a year of solemn rest (Shenat Shabbaton) for the land. And the Sabbath-produce of the land shall be food for you: for thee, and for thy 'ebet and for thy amah and for thy sakir and for thy toshab living 'immak (in thy employ); and for thy cattle and for the beasts that are in thy land, shall all the increase thereof be for food." 
"And the land shall yield her fruit, and ye shall eat until ye have enough, and dwell therein in safety. And if ye shall say: 'What shall we eat the seventh year? behold, we may not sow, nor gather in our increase;' then I will command My blessing upon you in the sixth year, and it shall bring forth produce for the three years. And ye shall sow the eighth year, and eat of the produce, the old store (yashan); until the ninth year, until her produce come in, ye shall eat the old store." ${ }_{22}$

That these two provisions refer to the same institution is, of course, obvious; but there are noteworthy distinctions.

In the former, the year is not given a name. There is no substantive for it. It is, however, characterized by the verbs shamat (to let it rest) and natash (lie fallow). From this verb shamat is derived the name for the releaseyear (shenat ha-shemittah) of Deuteronomy. ${ }^{83}$ This releaseyear, being the same seventh year, is closely related to the fallow-year of Exodus and to the Sabbatical year of Leviticus though it does not speak of the land. It was, what we call, a statute of limitations. These are its provisions:

"At the end of every seven years thou shalt make a release (shemittah). And this is the manner of the release: every creditor (ba'al mashsheh yado) shall release that which he hath lent unto his rea'; he shall not exact it of his rea' and his ah (brother); because the Lord's release hath been proclaimed. Of a nokri thou mayest exact it, but whatsoever of thine is with thy brother thy hand shall release unless the time should come when there shall be no ebyon among you. . ." ${ }_{84}$

The close relation between these three sorts of years was apparent to Nehemiah when a covenant was entered

82Lev. 25.2-7, 19-22. $\quad$ sDeut. 15.9; 31.10. "Deut. 15.1-4. 
into to observe the ancient laws among which were "the fallow year and the release year" (we-nittosh et ha-shanah ha-shebi it u-mashsha kol-yad). ${ }^{85}$ Note here the use of natash just as in the fallow-year provision of Exodus, and the conjunction with the release of debts (mashsha kol-yad), as in the limitation law of Deuteronomy.

From the consideration of the three groups of texts the following inference may be drawn:

a) The ancient inhabitants of Canaan whom Israel dispossessed, had probably the custom of the fallow in every seventh year.

b) This custom was, after the Conquest, continued by the Hebrews.

c) As was common in the ancient world, the Canaanite fallow was probably associated with pagan ideas and pagan practices.

d) The Exodus text contained no reference to religion but the Leviticus text was an essential portion of it, the two together being one complete ordinance. This Levitical section gave to the fallow year a specifically Hebrew religious character and even a specifically Hebrew religious name, Sabbatical year. It also supplied the data which were not expressed in the Exodus portion, namely a complete list of those entitled to eat of the fallow-year's produce, and specific directions as to the mode in which thrift should be exercised in order to avoid scarcity.

There were naturally to be store-houses-granaries. That the Hebrews were familiar with this mode appears plainly from the narrative of Joseph's advice to Pharaoh in Egypt. ${ }^{86}$ In these granaries the surplus portion of the crop of the sixth year was to be stored, which, with the natural produce of the seventh year, combined with such

${ }^{8 * N e h .10 .32 .}$

${ }^{96}$ Gen. 41.56. Though the Masoretic text of this verse may be somewhat defective, there is enough in it when combined with the Septuagint version to make the meaning unmistakable. 
of the crop of the eighth year as would be available for consumption in that year, would suffice to ward off suffering in the Sabbatical year and the year following it. By the ninth year, the bulk of the eighth year crop would be on hand and all danger would be past.

As regards the beneficiaries of the seventh year produce it is to be remarked, that the Levitical section specifies the farmer, his family, his slaves and his Canaanite laborers the sakir and the toshab. When the Hebrews had developed a class or classes of farm-laborers it was necessary to add them to the list and they were accordingly added as a new feature of the old common law, ebyone 'ammeka, the ebyonim of thy people. ${ }^{87}$ The word ebyonim is here used as a general term including all the Hebrew farm-laborers by whatever names their classes might on other occasions be known.

After this rather prolix treatment of the Exodus texts we may now pass on to the Levitical texts.

Of these there are but five, one referring to the rea', two to the 'ani and two to the dal. The ebyon is not mentioned in any of them.

The first, the rea' text is as follows:

"Thou shalt not oppress thy rea" nor rob him, (lo ta'ashok et re'eka we-lo tigzol); the wages of a sakir shall not abide with thee all night until the morning." 88 Here we have the rea' tied to the sakir, the wage-earner, and moreover we have the prohibition against oppressing or robbing him in about the same terms as similar ordinances against abusing other (non-Hebrew) workers are worded.

The 'ani texts are these:

The first of them prohibits reaping "the corner of thy field" and gathering "the gleaning of thy harvest" as also the gleaning of "thy vineyard;" "thou shalt

\footnotetext{
37Exod. 23.11. 88Lev. 19.13; Deut. 24.15.
} 
leave them for the "ani and for the ger." 89

The other of them provides: "When ye reap the harvest of your land, thou shalt not wholly reap the corner of thy field, neither shalt thou gather the gleaning of thy harvest; thou shalt leave them for the 'ani and for the ger." 90

The probability is that the term ger in these texts is used in a sense large enough to include the yatom and the almanah who are in fact part of the ger.

These texts further show that here, as in the Exodus texts, the Hebrew 'ani had been recognized as a class. When the analogous Deuteronomic ordinances were enacted, the beneficiaries were merely the ger, the yatom and the almanah. ${ }^{91}$ The "ani workers had not yet become of sufficient importance to be arrayed alongside of the classes of non-Hebrew workers.

The dal texts are these:

The first provides for an abatement of the offering demanded of the leper who is to be cured, "if he be $d a l$ and his means suffice not." ${ }_{92}$

The significance of this text lies in the fact that the $d a l$ is not released from the payment of a proper tax, although the amount thereof is reduced to suit his circumstances.

The other dal text is a substantial reiteration of the Exodus texts which dwell on the duty to do justice without fear or favor:

"Ye shall do no unrighteousness in judgment (mishpat); thou shalt not respect the person of the $d a l$, nor favor the person of the mighty (gadol); in righteousness shalt thou judge thy neighbor." 93

The only difference is in the wording and in the use of the dal and ebyon synonymously in the Exodus passages.

The Book of Numbers contains no texts having in

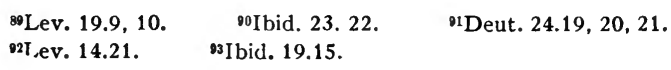


them any of the words we are considering. Deuteronomy, on the other hand, is rich in them, though it does not mention the dal.

The rea' texts in Deuteronomy are these:

"When thou dost lend thy rea" any manner of loan, thou shalt not go into his house to fetch his pledge. Thou shalt stand without, and the man to whom thou dost lend shall bring forth the pledge without unto thee. And if he be an 'ani, thou shalt not sleep with his pledge; thou shalt surely restore to him the pledge when the sun goeth down, that he may sleep in his garment, and bless thee; and it shall be righteousness unto thee before the Lord thy God." ${ }_{94}$

Hard upon this Deuteronomy text follows one relating to the sakir, 'ani we-ebyon.

The 'ani-ebyon texts are as follows:

"The ebyon shall never cease out of the land; therefore I command thee, saying: "Thou shalt surely open thy hand unto thy brother, unto thy 'ani and to thy ebyon in thy land." ",95

"Thou shalt not oppress (lo-ta'ashok) a sakir 'ani we-ebyon among thy brethren or among thy ger that are within thy land within thy gates (bi-sheareka). In the same day thou shalt give him his hire, neither shall the sun go down upon it; for he is 'ani and setteth his heart upon it. . ." 96

There appears to be no distinction between the 'ani and the ebyon in these texts. Moreover they appear to be used adjectively at times, the main thought being that persons well off in this world's goods should be kind and helpful to the poorer classes. The only workmen who are distinctly conceived as a class are the sakir, the laborers

94Deut. 24.10-13. 95Ibid. 15.11. 96Ibid. 24.12, 15. 
for daily wage The others seem to be visualized in the lump as "the poor."

The prophets are not reticent on the general subject.

Amos denouncing Israel charges that they sell the ebyon for a pair of shoes, ${ }^{97}$ that they pant after the dust of the earth on the head of the dallim and pervert the right of the "anawim, ${ }^{88}$ that they oppress the dallim ( $h a$ 'oshekot dallim) and crush the ebyonim,99 that they trample upon the dal and take from him exactions of wheat, ${ }^{\text {,oo }}$ that they turn aside the ebyonim in the gate (i.e. deny them justice in the court); ;or they swallow the ebyon and destroy the 'anawim of the land $\mathrm{d}^{102}$ and seek to buy the dallim for silver and the ebyon for a pair of shoes. ${ }^{103}$

The burthen of his complaint is that the nobility and gentry of the land are unmindful of the common people's welfare, look upon the latter as mere instruments of their pleasure and will certainly encounter a deserved doom. With him the 'ani, and the ebyon are the working masses of the country while the $d a l$ is the unsuccessful farmer.

Isaiah is not a whit more complaisant to Judah than Amos to Israel. He charges that the elders and the princes have the spoil (gezelat) of the 'ani in their houses, that they crush the people and "grind the face of the "aniyyim."

And, referring either to Judah or to Israel or to both he denounces "woe unto them that decree unrighteous decrees and to the writers that write iniquity; to turn aside the dallim from justice (din) and to rob of their right (ligzol mishpat) the "aniyyim of my people". . ."105

Even when he pictures an ideal government for the future he cannot forbear a thrust against the mean magnates of the present, the wicked 'ariș and the arrogant leș, who

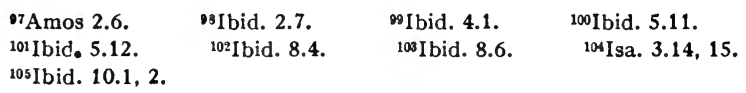


will in better times disappear with the consequence that the 'anawim shall rejoice in the Lord and the ebyonim shall exult in the Holy One of Israel.ro6

When a true Davidic type of king shall be restored, "with righteousness shall he judge the dallim and decide with equity for the "anawim of the land." ror

Jeremiah, too, berates the magnates of Judah: "They do not award justice (mishpat) to the ebyonim." "108

"Do justice between a man and his rea", oppress not ger, yatom or almanah."

He bitterly denounces the King Jehoiakim:

"Woe unto him that buildeth his palace by unrighteousness,

And his chambers by wrong,

That useth his rea"s service for naught

And giveth him no wage for it."

And contrasts his corruption with the righteousness of his father King Josiah: "He judged the cause of "ani and ebyon, and it went well with him."

When Babylonian supremacy made Zedekiah the last king of Judah before the Captivity, a wave of contrition seems to have swept over the land because of the breach of the laws relating to Hebrew laborers, slave and free. Under its influence there was enacted a solemn resolution to obey these laws in future. When the peril under which that action was taken seemed past, the old abuses were revived. This called forth Jeremiah's denunciation:

"Thus saith the Lord: Ye have not hearkened unto $\mathrm{Me}$ to proclaim liberty, every man to his brother and every man to his rea';" ${ }^{\prime 12}$ and therefore "I will give them into the hand of their enemies and into hand of them that seek their life." ${ }_{113}$

Ezekiel enumerates among his vicious criminals him

108I bid. 29.19, 20.

110Ibid. 22.13.
107Isa. 11.4. 111 Ibid. 22.16 .
${ }^{108} \mathrm{Jer} .5 .28$.

112Ibid. 34.17 .
${ }^{100}$ Ibid. 7.5, 6. ${ }^{113}$ Ibid. 34.20. 
that "hath wronged (honah) the "ani and the ebyon, taken by robbery (gezelot gazal)," ${ }_{114}$ and indicts the princes of Israel, for having committed grave crimes, among them having gained from their re im by extortion or oppression $(b e-' o s h e k)^{115}$ which profit he here stigmatizes as plunder $\left(\right.$ beșa $a^{b}$, just as in the text before quoted he calls it robbery.

Enlarging upon his theme, he inveighs against the 'am ha-areș for similar offences, which he characterizes as oppression('oshek) and robbery (gazel). The crimes charged are "having wronged (honu) 'ani and ebyon and oppressed the ger contrary to law. ${ }^{\text {II }}$

Zechariah speaks in the same strain:

"Thus hath the Lord of hosts spoken, saying, Execute true justice, show mercy and compassion every man to his brother. Oppress not (al-ta'ashoku) almanah, yatom, ger or 'ani. . ." ${ }_{117}$

Malachi while speaking on the same subject makes no mention of a specific class of Hebrew laborers. While he warns against unfair treatment of sakir, almanah, yatom or ger, he does not mention rea', 'ani, dal or ebyon. As he probably lived and worked during or shortly after the advent of Ezra and Nehemiah, the inference is not remote that in the restored Commonwealth, the Hebrew laborers held a position superior to that which had been theirs before the Captivity. The social conflict, between the nobility and gentry on the one hand and the laborers and the less successful farmers on the other, had been greatly reduced. The fifth chapter of Nehemiah seems to confirm this view. ${ }^{118}$

The Proverbs too throw light on our subject:

- "The oppressor ('oshek) of the dal blasphemeth his Maker,

But he that is gracious to the ebyon honoreth Him." 119

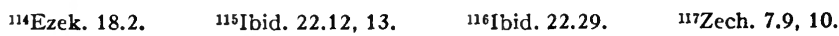

${ }^{118}$ Neh. 5.1-13. 119 Prov. 14.31 .
} 
"Say not unto thy rea", Go and come again,

To-morrow I will give-when thou hast it by thee." Lord." 121

"He that is gracious to the dal lendeth unto the

"He that oppresseth the dal for gain

Will pay to the rich ("ashir) and come to want."

"Do not rob (al-tigzol) the dal, because he is dal,

Nor crush the "ani in the gate" (at the local court sitting in the gate). ${ }^{123}$

"The king that faithfully judges the dallim

His throne shall be established forever." ${ }_{124}$

"There is a generation whose teeth are as swords, and their great teeth as knives,

To devour the aniyyim from off the earth, and the ebyonim from among men." ${ }_{125}$

"Open thy mouth, judge righteously,

The cause of "ani and ebyon." 126

Job too describes transgressors of the kind we have been considering:

"They drive away the ass of the yetomim,

They take the almanah's ox for a pledge,

They turn the ebyonim from their right,

The "anawim of the land hide themselves together."

"They take pledge from the 'ani

So that they go about naked, without clothing,

Carry sheaves and remain hungry,

Tread winepresses and suffer thirst." ${ }^{228}$

The conclusion to be derived from the texts is that the various names for the Hebrew poorer classes, did not originally suggest any great disparity among them. Their multiplicity may have been due to local, to temporary or to dialectal causes. 
The notion that they were all recipients of charity is old and wide-spread. Indeed, in one instance A. V. goes so far as to translate ebyon, straightway, by beggar. ${ }^{\text {I29 }}$

My hope is that such ideas may be finally dismissed.

Actual beggars or actual beggary is perhaps nowhere mentioned in the Bible. The two strongest passages referring to it are to be found in the Psalms. They are both utterances of the lowly spirit.

The first is the thirty-seventh Psalm.

It rejoices in the prospect that the 'anawim shall inherit the land ${ }^{130}$ and that the wicked who design to depress the 'ani we-ebyon shall be baffled, ${ }^{\mathrm{x} 3 \mathrm{I}}$ and sums up experience in this hopeful strain: "I have been young and now I am old, yet have I not seen the innocent forsaken nor his seed begging bread (mebakkesh lehem). ${ }^{\mathrm{1} 32}$

The second is the one hundred and ninth Psalm. The Psalmist is represented as dwelling on the malignity of his enemies and invoking against them and their progeny the sternest retributive justice: "Let his children be vagabonds and beg. . ." (we-shielu). ${ }^{\mathrm{r} 33}$ Such a fate he demands for the powerful oppressor who "persecuted the "ani we-ebyon." ${ }_{334}$

While the picture of beggary, present in the mind of the Psalmist, must have been derived from life, yet it presents no actual condition, but is in both cases an imaginative suggestion. Certain it is that the 'ani we-ebyon whose voice we hear has nothing in common with this hypothetical beggar nor with any actual beggar. He may, it is true, be subject to oppression by his employer, but he can have recourse to the Courts and he will obtain justice. Indeed there is nothing more admirable in any system of jurisprudence than the principles laid down in the Mosaic law to govern the administration of justice.

\footnotetext{
1291 Sam. 2.8. $\quad{ }^{130}$ Psalm 37.11. $\quad{ }^{131}$ Ibid. 37.14. $\quad{ }^{132} \mathrm{Ibid}$. 37.25.

13s I bid. 109.10. 134 Ibid. 109.16.
} 
The charge of Moses to the judges was:

"Hear the causes between your brethren, and judge righteously between a man and his brother, and between a man and his ger. Ye shall not respect persons in judgment, ye shall hear the small (katon) and the great (gadol) alike; ye shall fear no man, for justice (mishpat) is God's." ${ }^{135}$

An important Exodus passage indicates the danger that tribunals might be influenced by popular prejudice, the voice of the crowd.

"Thou shalt not follow the crowd (rabbim) to do evil, . . . to pervert justice;" and do not favor the dal in his cause (be-ribo). Thou shalt not wrest the judgment (mishpat) of thy ebyon in his cause. ${ }^{\mathrm{r} 36}$

"Ye shall do no unrighteousness in judgment (mishpat); thou shalt not favor the dal or the gadol; but in righteousness shalt thou judge thy neighbor ('amiteka)." ${ }^{137}$

"Thou shalt not wrest judgment, thou shalt not respect persons, nor take a gift. . . " ${ }_{238}$

"Thou shalt not pervert the justice due to the ger. . ." ${ }_{139}$

"Cursed be he that perverteth the justice due to the ger. . ." ${ }_{140}$

Isaiah, denouncing injustice in the courts declares that unrighteous judges "turn aside the dallim from justice (din) and rob (gazal), 'aniyyim of their right (mishpat)..." ${ }^{145}$

Jeremiah too declares of such that they do not judge the right (mishpat) of ebyonim." ${ }_{142}$

Whatever the origin of the four names for the Hebrew poorer classes, it would appear that in the event only one of them developed a specific and peculiar meaning. This was the dal.

Just as the landless Canaanites had become the sakir and those who had been landholders before the Conquest had become the toshab, so there was a somewhat similar

\footnotetext{
${ }^{136}$ Deut. 1.16, 17. $\quad{ }^{136}{ }^{2}$ Exod. 23.2, 3, 6. $\quad{ }^{137}$ Lev. 19.15. $\quad{ }^{138 D e u t . ~ 16.19 . ~}$ 
movement among the Hebrews. The landless ones became in general, the ebyon, the 'ani, the rea' and later on the sakir, while the landholders who were in danger of losing their farms or who had actually lost them became the dal.

Amos, in the eighth century B.C., denouncing the Northern government (Israel) declares that "it tramples upon the dal" taking from him unreasonable proportions of his wheat, and rails at the luxury and extravagance of those who thus abused their taxing-power. This burdensome wheat-tax he calls mas'at-bar. ${ }^{143}$

That even before Amos, there were unsuccessful landowners appears incidentally in the narrative which tells of the selection of Gideon to be the shofet of Israel. When the deputation waited on him to tender him the great office, he was found threshing wheat. In his reply he modestly deprecated his fitness for the post describing his family or clan as $d a l$ and himself as its humblest member. ${ }^{144}$

The $d a l$ farmers persisted as a class until the downfall of the Judean Kingdom (586 B.C.) and even then, they were not deported but were favored by the Babylonian Conquerors.

The record, after reciting the classes that were deported, adds: None remained save the dallat 'am haares ${ }^{145}$ or as they are otherwise called dallat-ha-ares, who were left to be vine-dressers and husbandmen. ${ }^{\mathrm{I} 46}$

The policy of the Babylonian conquerors was to deport the magnates and the powerful, but to leave the $d a l$ at home to continue the cultivation of the land.

And now to sum up the result of our inquiries:

At the final conquest of Canaan, the Hebrews took the land of the Canaanites and divided it among themselves, retaining the previous inhabitants as workingmen. Most of these remained settled on the land as a peasant

${ }^{143}$ Amos 5.11. 144 Jud. 6.15. $\quad 1452$ Kings 24.14.

14I Ibid. 25.12; Jer. 52.15, 16. 
population and these were called toshabim, while those who were not so settled worked for daily wage as sekirim. The general term applied to both classes was ger (literally, stranger). When one of these gerim died his family were not driven out of their humble cottage, but remained on the land and worked on it. Hence the locution ger, yatom we-almanah which occurs so frequently as descriptive of the conquered population.

This word ger has undergone curious transformations. At first and for many centuries it simply meant stranger. When Abraham, in addressing the Hittites, called himself a ger he used the word in that sense. After the Hebrew conquest had subjected the Canaanites, it acquired the additional meaning of laborer, and this it retained during the whole period covered by the Biblical writings, even to a time when the ger had been thoroughly absorbed in Israel and the distinction had no application in real life. The Book of Proverbs so replete with keen observation and profound reflection on social conditions never mentions the word, while it speaks abundantly of the ebyon, the $d a l$ and the 'ani classes of workingmen. When it was written, say three hundred years before the present era, the descendants of the ger were undoubtedly classed with the Hebrew workingmen and were not known by any other name. The only way in which the word survived was that in consequence of the historical facts, it gradually and insensibly came to mean a proselyte. It had acquired that meaning more than two thousand years ago when the Greek translation of the Bible, called the Septuagint, was made. Wherever the text refers to the gerim we have been considering, the Greek version, without much regard for historic probability, but evidently in accord with current speech, renders proselyte. Its earliest use in that sense in any Hebrew writing that I know of, is in the Mishnah, 
written probably about the year 200 of our present era, though it had probably been used in common speech for centuries before, to designate individuals of foreign stock coming in to adopt the religion of the Hebrews. That meaning it retains to this day. It is a curious philological phenomenon that while this use persisted in speech, it was eschewed in Hebrew writing. When, in the Book of Esther (written perhaps contemporaneously with the Septuagint) such proselytes are spoken of, they were not called ger nor indeed by any other substantive. They were described by the action taken by them, for which purpose the Hebrew writer invented a new reflexive verb. There is but one instance of its use: Esther 8.17, and this in the form of a participle: mityahadim or as we might say "judaizing themselves."

Closely associated with this ger in the records, is another class called the ezrah. They are not mentioned as being either workmen or as belonging to the poor. Their position as regards civil status seems to be on a parity with that of the whole body of Israel. The only difference is in religious matters. From what the texts tell us we may fairly infer that they were a large and compact body of voluntary proselytes, and the only clue to such a movement leads us back to the very beginning of the Hebrew nation. At the Exodus from Egypt, a considerable body of Egyptian natives attached themselves to Israel with the determination to become a part thereof and to share its fate. The records give us two contemptuous names for them: 'ereb rab and asafsuf, both fairly rendered by "the rabble." That there should have been no right name for them seems impossible. When we reflect that the Israelites looked upon themselves as gerim in Egypt, the probability that by way of contrast they called these Egyptians "natives" seems reasonable. In their language, 
ezrah meant native and the conclusion is easy to reach that this body of proselytes was called ezrah.

From the texts it plainly appears that their reception was cold. Willing as they undoubtedly were to assume all the duties, civil, military and religious, imposed on Israelites, the latter would not at once admit them to full religious equality, but insisted that they should rise to that height, by degrees. Notwithstanding this repugnance, their full assimilation to Israel must have been achieved at a very early period, since they were held up to the ger as an example and a model whom they should imitate and might hope to reach. It is significant that none of the prophets ever mentions the ezrah save only Ezekiel in the course of a vision replete with learned historical memories.

The stages of the advance of the ezrah and of the ger to full membership in Israel, I have endeavored to sketch. At all events, the end was reached, though the memory of their different origins was not quite effaced for centuries. To the great body of Canaanite workmen and their progeny, there was finally added a large Hebrew element.

The dream of an equality of property and of prosperity indulged in by the conquerors was, naturally, not realized.

Whether there was a piece of land assigned to every householder is doubtful. There were probably many who never received any. But even if this were not so, there would be not only differences of soil and climate but disparity of ability and efficiency, both causes of varying results. Despite the best intentions, some grew rich and others slid into poverty.

It was inevitable that classes of Hebrew laborers would be formed, and to these were given names: ebyon, 'ani, dal and finally rea'. Of all these classes only one, the $d a l$ came to mean the unsuccessful farmer, who, though he did not prosper, was still able to hold on to his land 
cultivating it by the aid of his wife and children and in many cases supplementing its insufficient returns by working part of the time for others, and receiving wages therefor.

Needless to say, extreme prosperity in some raised a brood of greedy and avaricious men ready to tyrannize over their poorly-endowed neighbors.

The whole Biblical literature shows an age-long struggle against this class and in behalf of the poor, and establishes the fact that the movement in favor of the latter was largely successful, so that not only the Hebrew laborer but the ger were greatly improved in condition, more especially after the Return from Babylon.

Classes of beggars or paupers there were none. The frequent use of words denoting poverty meant no more than to mark out the line between the rich and those who had to earn their living by manual labor.

In a word the stranger and the poor of our versions, were both important and useful constituent parts of the body of Israel, and were, in the last analysis, neither strange nor poor, because they fully shared in the intimate life of the community and earned an honest living by their labor in its behalf.

So that we may fairly say that a great movement for the protection and improvement of the laboring mass was initiated in Israel more than three thousand years ago and continued to permeate its life and its literature, becoming indeed a part of the mental constitution of the people.

While the records of the Bible on the subject may not have been fully appreciated, the main fact could not be ignored and by the wide diffusion of the Book it has penetrated into every nook and corner of the civilized 
world and changed institutions and governments. To close with the words of Zangwill, the Bible "transcends the race that produced it, like all great literature, though none other has, in the same degree carried a message to every race and grade of mankind." ${ }^{47}$ 
, 


\section{INDEX OF BIBLICAL PASSAGES}

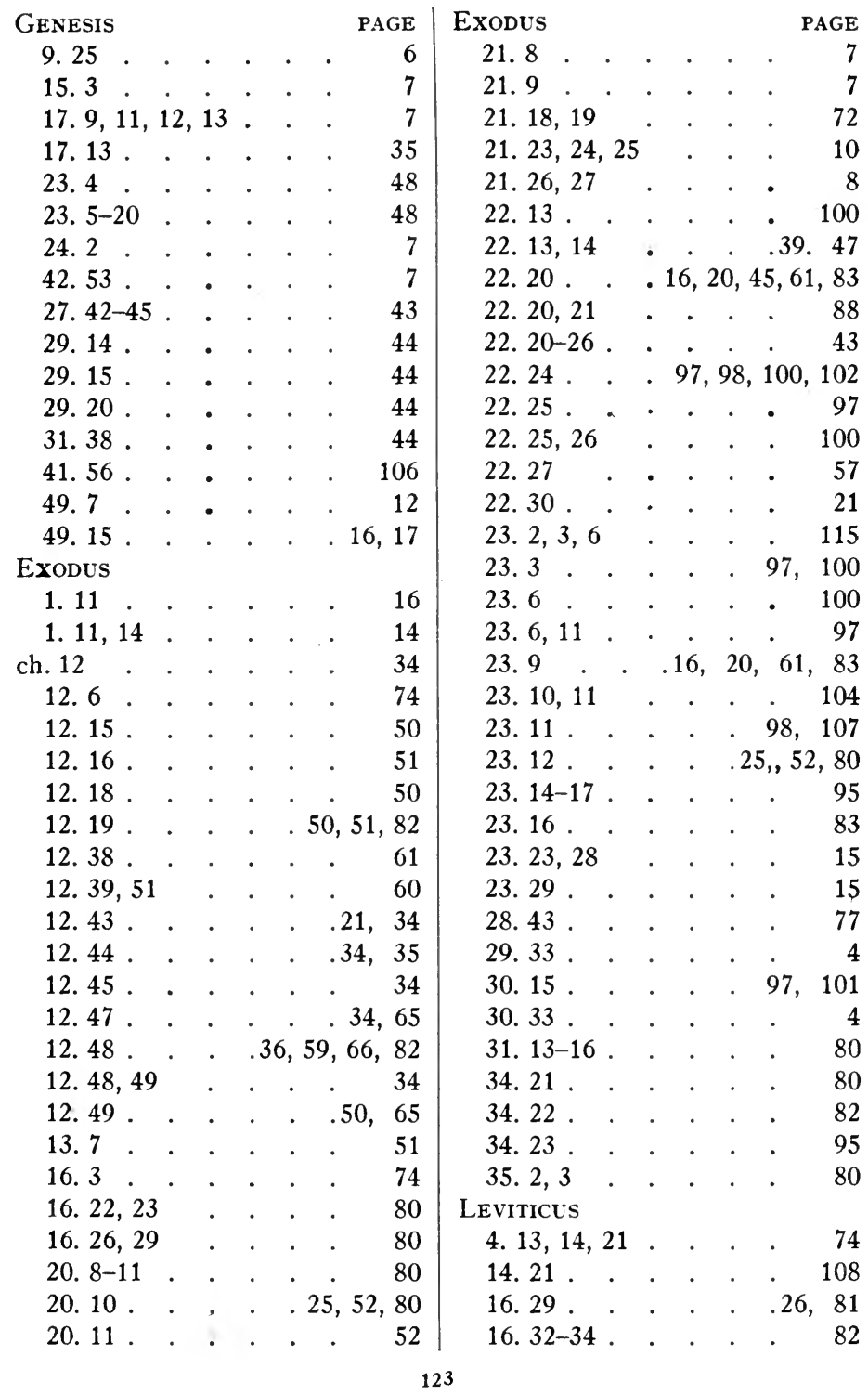




\begin{tabular}{|c|c|c|c|c|c|c|c|c|}
\hline \multirow{2}{*}{$\begin{array}{l}\text { Leviticus } \\
\text { 17. } 3,4,8,9 \\
17.9\end{array}$} & & & PAGE & Leviticus & & & & PAGE \\
\hline & 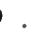 & . & 55 & 25.45 & . & & . & 49 \\
\hline & . & . & 56 & 25.47. & . & & - & 49 \\
\hline 17. 10 . & . & . & 56 & 25. 47-54. & . & & . & 38 \\
\hline 17. 12 . & . & . & 56 & 25.50. & . & & . & 33 \\
\hline 17.15. & . & . & 21 & $25.50,53$ & . & & . & 45 \\
\hline $17.15,16$ & . & . & 77 & 25.53 . . & . & & . & 34 \\
\hline 18.21. & . & . & . 56 & 26. 25 . & . & & . & 10 \\
\hline 18. 26 . & . & . & $.56,79$ & Numbers & & & & \\
\hline 18.27 . & . & . & . $\quad 56$ & 1. 2,3 & . & & . & 41 \\
\hline 19. 3,30 & . & . & . $\quad 80$ & 1.51 . & . & & . & 4 \\
\hline 19. 9,10 & . & .8 & $84, \quad 108$ & 3. 10,38 & . & & . & 4 \\
\hline 19. 13 . & . & $.43,85$, & 5,90107 & 9. $1-14$ & . & & . & . $\quad 34$ \\
\hline 19.15. & . & $.98,108$ & $08, \quad 115$ & 9.14. & . & & . & $.50,85$ \\
\hline 19. $16,17,18$ & & . . . & 98 & 10.7 & . & & . & . $\quad 74$ \\
\hline 19.33. & . & . . . & $.45,83$ & 11.4 . & . & & . & $.61,62$ \\
\hline 19.34 . & 20 , & 61,63 & $, 86,98$ & 12. $1-5$ & . & & . & . 61 \\
\hline 20.2 . & . & • . & 56 & 14.5. & . & & . & 74 \\
\hline $20.4,5$ & . & . & 57 & 15. $2,13-16$ & 6 & & . & 74 \\
\hline 22.10. & . & . & 37 & 15.16. & . & & . & 85 \\
\hline $22.10,11$ & . & . & 36 & 15. 25 . & . & & . & 76 \\
\hline 22. $10,12,13$ & & . & 4 & 15. 26. & . & & . . . & $.74,76$ \\
\hline $22.13 \quad$ & . & . & 92 & 15. 29 . & . & & $.63,65$, & $5,76,85$ \\
\hline 22.25 & . & . & 21 & 15.30 & . & & . . . & . 65 \\
\hline 23.3. & . & . & 80 & 16. 3,33 . & - & & . & 74 \\
\hline 23. 7,8 . & . & . & 51 & 16. 29 . & - & & . & 51 \\
\hline 23. 16-21. & . & . & 82 & 17.5 & . & & . & 4 \\
\hline 23.21 . & . & . & . 54 & 1712 . & . & & . & 74 \\
\hline 23.22 . & . & . & 84,108 & $18.4,7$ & . & & . & 4 \\
\hline 23.24 . . & . & . & . 82 & 18. 22 & . & & . & 77 \\
\hline 23. 24,25 & . & . & . $\quad 52$ & ch. 19 . & . & & - & 76 \\
\hline 23. $27-32$ & . & . & $.51,82$ & 19. 20 & . & & . & 74 \\
\hline 23. $34,39-43$ & & . & . 83 & $20.4,6,10$, & , 12 & & . & 74 \\
\hline $23.40,42,43$ & & . & 55 & $20.14-24$ & . & & . & 24 \\
\hline 23.42. & . & . & 62 & 21. $22-31$. & . & & . & 24 \\
\hline 23.43 . & . & . & 63 & 22.4 . & . & & . & 74 \\
\hline 24. $10-16$. & . & - & 57 & $28.18,25$ & & & . & 51 \\
\hline 24. 17-22. & . & . & 71 & 29.1. & . & & . & $.52,82$ \\
\hline 24.20 . . & . & . & 10 & 29.7. & . & & . & $.51,81$ \\
\hline 24.22 . . & . & . & 85 & $29.12,35$ & $\cdot$ & & . & 54 \\
\hline 25. $2-7,19-22$ & & . & 105 & 29. 12-39. & . & & . & 83 \\
\hline $25.4-6$. & . & . & 37 & 29.35 . . & . & & . & 54 \\
\hline 25.6. & . & . & 85 & 32. $1-42$ & . & & . & 5 \\
\hline 25.10 & - & . & 48 & 35.15. & . & & . & 73 \\
\hline 25.23 . & • & . & 48 & 35. $22-29$ & . & & . & 73 \\
\hline 25. 34,40 & • & . & 37 & DEUTERONOMY & & & & \\
\hline 25. 35-37. & $\cdot$ & . & 102 & 1.16 & . & & . & $.26,85$ \\
\hline 25.44 . & . & . & 48 & 1. 16,17 . & & & . & . $\quad 115$ \\
\hline
\end{tabular}




\begin{tabular}{|c|c|c|c|c|c|c|c|c|}
\hline EUTERONON & & & & PAGE & DEuteronomy & & & PAGE \\
\hline $5.14 \ldots$ & . & & $.25,5$ & $; 2,80,81$ & 23. $2,3,4,9$ & . & . & . $\quad 74$ \\
\hline 5.15 . & . & & $\cdot \quad \cdot$ & . 52 & 23.8 . & . & . & $.16,61$ \\
\hline 6. 10,11 & . & & . & 14 & 23. 16,17 & . & . & . 45 \\
\hline 7.22 . & . & & . & 15 & 23. 20,21 & & . & 102 \\
\hline 8. $7,8,9$ & . & & . & 14 & 23. 21 . & & . & 21 \\
\hline 9.10 . & . & & . & 74 & 24. $10-13$ & . & . & 109 \\
\hline 10.4 , & . & & . & 74 & 24. 12,15 & - & . & 109 \\
\hline 10. 8,9 & . & & . & 13 & 24.14 . & & . & . $\quad 98$ \\
\hline 10.18 & . & & . & 91 & 24. 14,15 . & . & . & $.41,85$ \\
\hline 10. 18,19 & - & & . & 86 & 24.15 . . & - & & $.90,107$ \\
\hline 10. 19 . & & & 16 , & 20 & 24.17 . & & $.85,91$ & $91, \quad 115$ \\
\hline 11. 10,11 & - & & $\cdot$ & 13 & 24.19. & & . $\cdot$. & . $\quad 91$ \\
\hline 11. 17. & & & . & 14 & 24. $19,20,21$ & & . & 84,108 \\
\hline 4,2 & & & . & 14 & 24. 20 . . & & . & . $\quad 91$ \\
\hline 14. 3,21 & . & & . & 76 & 24. 20,21 & & . & 90 \\
\hline 14. 21 . & . & & & $.21,77$ & 24.21. & & . & 92 \\
\hline 14. $23-25$ & . & & . & $\begin{array}{ll}.21, & 14 \\
. & 14\end{array}$ & 25.5 . & & . & 4 \\
\hline 14. $23-27$ & . & & . & - & 26. 2 . . & & . & 14 \\
\hline 14. 28,29 & . & & . & $\begin{array}{r}05 \\
77,85\end{array}$ & $26.12,13$ & & 77,8 & 85 \\
\hline 29. & . & & . & $\begin{array}{r}.77,85 \\
90,94\end{array}$ & 27.7 & & • & 83 \\
\hline $1-4$ & . & & $\cdot$ & $.90,94$ & 27. 17 . & & . . . . & 93 \\
\hline 7 & . & & . & . 105 & 27.19 . . & & $.85,91$ & 115 \\
\hline 9 . & . & & . & . $\quad 98$ & 28. 43,44 & & .78 & 102 \\
\hline 11. & . & & · & $98, \quad 105$ & 29.1 & & . & 78 \\
\hline 16 & & & . & 98,109 & 29. $1,9,10$ & & . & 25 \\
\hline & $\cdot$ & & . & 45 & 29.8 & & . & 78 \\
\hline 18 & - & & . & 33 & 29. 9-11. & & . & 78 \\
\hline 20 & . & & . & 14 & $29.13,14$ & & . & 78 \\
\hline 16. $2-16$ & . & & . & . 14 & 31.9 . & & . & . $\quad 78$ \\
\hline .3 & . & & . & $.50,82$ & 31.10 . & & . & 63,105 \\
\hline .4 & . & . & . & . $\quad 51$ & 31.11. & & . & $.14,79$ \\
\hline 16. 8 & . & • & . & 51 & $31.12,13$ & & . & . 79 \\
\hline 16. $9-11$ & . & & . & . 54 & 32.16 . & & . & . \\
\hline 16. 11. & . & & . & $.83,94$ & 33.4 . & & . & 74 \\
\hline 11 & & & . & . $\quad 90$ & & & & \\
\hline 16. $13-17$ & & & . & . 63 & Jos & & . & \\
\hline 6. 14 & . & & . & $.54,94$ & 6. $22-25$ & & . & 15 \\
\hline 15 & . & & . & 83 & 8.26 . & & . & 15 \\
\hline 16 & . & & . & 95 & $32,33,35$ & & . & 79 \\
\hline 19 & . & & . & 115 & 8.35. & & . & 75 \\
\hline $.8-10$ & . & & . & 14 & 9. 3-15 & & . & 15 \\
\hline 18.6. & . & & . & 14 & 19. & & . & 15 \\
\hline 6,78 & & & . & 96 & 9. 20,21 . & & . & . 16 \\
\hline 16 & . & & . & 74 & 9.23. & & . & . 6,16 \\
\hline .14. & $\cdot$ & & - & 92 & 9. $25-27$ & & . & . $\quad 16$ \\
\hline 19. 21 . & . & & . & 10 & 14. 11 . & & . & 41 \\
\hline 20. 17 & . & & . & 15 & 20.9 . & & & 73 \\
\hline
\end{tabular}




\begin{tabular}{|c|c|c|c|c|c|c|c|c|c|c|c|}
\hline UDGES & & & & & PAGE & ISAIAH & & & & & PAGE \\
\hline 1. 19 & & & & & 18 & 2. $2-4$ & & & & & 23 \\
\hline 1. $19-25$ & & & & & 17 & 2.6 & & & & . & 21 \\
\hline 1. 21 . & . & & & & 18 & 3. 14,15 & & & & . & 110 \\
\hline $3.5 \quad$ & & & & & 19 & 5.8 . & & & & & 93 \\
\hline 5. 1-31 & & & 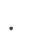 & . & 18 & 10. 1,2 & & & & . & 110 \\
\hline 5.15 . & & & . & . & 18 & 10. 2 . & & & & . & 115 \\
\hline 6. 15 & . & & & & 116 & 11.4 & & & & & 111 \\
\hline 10.1 & & & & 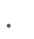 & 18 & 16. 14 & & & & . & 33 \\
\hline h. 17 & & & . & . & 95 & 23.17 . & & & & . & 103 \\
\hline 17. 5-15 & & & 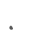 & . & 54 & $29.19,20$ & & & & . & 111 \\
\hline 17. $7-13$ & & & & & 46 & 43. 12 . & & & & . & 4 \\
\hline 17. 10 & & & - & . & $.45,96$ & $58.13,14$ & & & & & 53 \\
\hline 19. 12 . & . & & . & 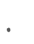 & . $\quad 21$ & 61.5 & & & & . & 4 \\
\hline 1 Samuel & & & & & & JEREMIAH & & & & & \\
\hline 1. 28 . & . & . & . & . & 46 & 19 . & & & & . & 4 \\
\hline ch. 1-3 & . & . & . & . & 46 & 5. 28 & & & & 111 & 115 \\
\hline 2. 8 & . & & 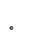 & . & 114 & 7.5 & & & & . . & 97 \\
\hline 2. 11,18 & . & . & . & . & 46 & 7. 5,6 & & & & 42,89 & 111 \\
\hline 2.21 . & . & . & . & . & 45 & 7.6 & & & . & . . & 85 \\
\hline 3.1 & . & . & . & . & 46 & 16. 18 . & . & & . & . & 76 \\
\hline 11. 15 & . & & . & . & 83 & 17. $21-27$ & & & &.$\quad$. & 53 \\
\hline 2 SAMUEL & & & & & & 22.3 . & & & & $.45,85$ & 89 \\
\hline 20.24 & . & . & . & . & 26 & 22.13 & & & . & 42,97 & 111 \\
\hline $1 \mathrm{KINGS}$ & & & & & & 22. $15-17$ & & & & . . & 42 \\
\hline 4. 6 & . & . & . & . & 27 & 22.16 . & & & . & . & 111 \\
\hline 5. 28 & . & . & . & . & 27 & 22. 17 . & & & . & . & 97 \\
\hline 8. 2,65 & . & . & . & . & 95 & 26. & & & & . & 74 \\
\hline 8. 14,22 & . & . & . & . & 74 & 34.17 . & & & . & , 42, & 111 \\
\hline 8. 4 & . & . & . & . & 22 & 34.19 . & & & &.$\quad$. & 42 \\
\hline $9.15-19$ & . & . & . & . & 26 & 34. 20 . & & & & . & 111 \\
\hline 9. 20,21 & . & . & . & . & 27 & 39.10 . & & & & . & 98 \\
\hline 9. $20-22$ & . & . & . & . & 30 & 51.2 . & 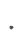 & & & . & 4 \\
\hline 11. 26. & . & . & . & . & 28 & $52.15,16$ & & & . & . & 116 \\
\hline 11.40 & . & . & . & . & 29 & EzEK & & & & & \\
\hline 12.3 & . & . & . & . & 74 & 11.9 & & . & . & . & 4 \\
\hline 12. 3,4 & . & . & . & . & 29 & 14. 7,8 & & & . & . & 79 \\
\hline 12. 14,16 & & . & . & . & 29 & 16. 3 & & & . & . & 19 \\
\hline 12. 18 . & . & . & . & . & 27 & 18. 2 & & . & . & . & 112 \\
\hline 12. $29-33$ & . & . & . & . & 29 & 18. 12. & & . & . & . & 45 \\
\hline 12.42 & . & . & . & . & 27 & 18. 13. & & $\cdot$ & • & . & 103 \\
\hline 2 KINGS & & & & & & 22.7 & & & & .42 , & 89 \\
\hline 4. 23 . & . & . & . & . & 53 & 22. 7,29 & & & . & .45 & 85 \\
\hline 23. 23 & . & . & . & . & 95 & 22. 12 & & . & . & .42 & 97 \\
\hline 24. 14 . & . & . & . & . & 116 & 22. 12,13 & & . & . &. & 112 \\
\hline 25.12 & . & . & . & . & 116 & 22. 29 . & & . & . & 97 & 112 \\
\hline ISAIAH & & & & & & 27.3 & & . & . & . & 103 \\
\hline 1. 7 & . & & . & & 4 & 28. 7,10 & & & & . & 4 \\
\hline
\end{tabular}




\begin{tabular}{|c|c|c|c|c|c|c|c|c|c|c|c|c|}
\hline ZEKIEL & & & & & & PAGE & Proverbs & & & & & PAGE \\
\hline 30.12 & . & . & . & . & . & 4 & 5.10 & $\cdot$ & • & & • & 22 \\
\hline 31.12 & . & . & . & . & . & 4 & 6. 24 & . & & & & 22 \\
\hline 44. 7,9 & . & . & . & . & . & 21 & 7.5 . & 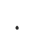 & & & & 22 \\
\hline 47. 22 & & & . & . & .63 & 66 & 14. 21 . & & & & & 42 \\
\hline IOSEA & & & & & & & 14. 31 . & & . & & & 112 \\
\hline 5. 10 & . & . & . & . & . & 93 & 15. 25 . & & . & & & 92 \\
\hline 7. 9 & . & . & . & . & . & 4 & 19. 17 . & & & & & 113 \\
\hline 8. 7,12 & . & . & . & . & . & . 4 & 20.16 . & . & & & & 22 \\
\hline 12.10. & . & . & . & . & . & 63 & 21. 24 & & & & & 99 \\
\hline MOS & & & & & & & 22. 16 . & & . & & & 113 \\
\hline 2. 6 & . & . & . & . & . & 110 & 22. 20 . & & & & & 93 \\
\hline 2. 7 & . & . & . & . & 93, & 110 & 22. 22 . & & & & & 113 \\
\hline 4. 1 & . & . & . & . & . & 110 & 23.10 & . & & & & 92 \\
\hline 5.11 & . & . & . & . & 110 & , 116 & 27. 13 . & . & . & & & 22 \\
\hline 5. 12 & . & . & . & . & . & 110 & 28.8 . & . & . & & & 103 \\
\hline 7.13 & . & . & . & . & . & 29 & 3. 11 . & . & & & & 99 \\
\hline 8.4 & . & . & . & . & . & 110 & 9.14 . & & & & & 113 \\
\hline 8. 6 & . & . & 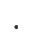 & 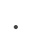 & . & 110 & 30.14 . & . & & & & 113 \\
\hline OBADIAH & & & & & & & 31.9 . & . & . & 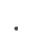 & & 113 \\
\hline 1.11. & . & . & . & . & . & 21 & 31. 24 & . & & & & 103 \\
\hline MICAH & & & & & & & JoB & & & & & \\
\hline 2. 1,2 & . & . & . & . & . & 94 & 2. 9 & $\cdot$ & & & & 58 \\
\hline 2. 5 & . & . & . & . & . & 74 & 7. 1 & . & & & & 33 \\
\hline 4. 1-4. & . & . & . & . & . & 23 & 14.6. & . & & & & . $\quad 33$ \\
\hline ZEPHANIAH & & & & & & & 19. 15 . & & . & & & . 4,22 \\
\hline 1.8 & . & . & . & . & . & 21 & & . & & & & . $\quad 92$ \\
\hline ZECHA & . & . & & & & & 24. 3,4 & . & & & & 113 \\
\hline 7. 9 , & . & . & . & . & . & 112 & 24. $3-12$ & . & & & & 88 \\
\hline 7.10 . & . & .. & & . & . & 89 & 24. 9,10 , & 11 & . & & & 113 \\
\hline MALACHI & & & & & & & 40. 30 & & . & & & 103 \\
\hline 3.5 . & . & . & $\cdot$ & 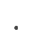 & .85 & 89 & RuTh & & & & & \\
\hline SALMS & & & & & & & 2. 8,9 & $\cdot$ & & & & 88 \\
\hline 15.5 . & & . & . & . & . & 103 & LAMENTATIC & ONS & & . & 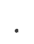 & . \\
\hline 37.11 . & . & . & . & . & . & 114 & 5.2 & . & . & . & . & 21 \\
\hline 37. 14 . & . & . & . & . & . & 114 & Ecclesiast & & . & . & & \\
\hline 37.25 & . & . & . & . & . & 114 & 6.2 & . & . & $\cdot$ & . & 22 \\
\hline 44. 21 . & . & . & . & . & . & 4 & EzRA & & & & & \\
\hline 69.9 . & . & . & . & . & . & 22 & 9. 1,2 & . & . & . & . & 20 \\
\hline 81. 10. & . & . & . & . & . & 4 & Nehemiah & & & & & \\
\hline 90.10 . & . & . & . & . & . & 41 & & . & . & & & 112 \\
\hline 109.10 & . & . & . & . & . & 114 & -18 & . & . & & & 83 \\
\hline 109.16 & & . & . & . & . & 114 & 8. & . & . & & . & 95 \\
\hline 144. 8,11 & & . & . & . & . & 22 & 10. 32 & & & . & . & 106 \\
\hline PROVERBS & & & & & & & 1 Chronicl & & & & & \\
\hline 2.16 . & . & . & . & & . & 22 & 13. 2,4 & . & . & & & 74 \\
\hline 3. 28 & . & . & . & & $\cdot$ & 113 & 28.8 & $\cdot$ & . & & & 74 \\
\hline 3.34 & . & . & . & & . & 99 & 29. 1,10 , & 20 & & & & 74 \\
\hline
\end{tabular}




\begin{tabular}{|c|c|c|c|c|c|c|c|c|c|}
\hline Chronicle & & & & & PAGE & 2 ChRONICLES & & & AGE \\
\hline 1. 3,5 & . & . & & & 74 & 23.3. & . & . & 74 \\
\hline 2. 16 & . & . & . & & 27 & 24.6 . & & . & 74 \\
\hline 6. $3,12,13$ & . & . & . & & 74 & 28.14 & . & . & 74 \\
\hline 6.32. & . & . & . & & 22 & 29. $23,28,31,32$. & & . & 74 \\
\hline 7. 8,9 & . & . & . & & 95 & 30. $17,23,24,25$. & & . & 74 \\
\hline 8. $1-6$. & . & . & . & • & 26 & 30.25 . & & .18 & 75 \\
\hline 8. 7,8 & . & . & . & & 27 & MishNAH & & & \\
\hline 8. 7-9. & . & . & . & & 30 & BABA MEșI'A 8.1 & & . & 47 \\
\hline 10. 18 & . & $\cdot$ & . & & 27 & New Testayent & & & \\
\hline 20.5 . & . & . & . & & 74 & LUKE 10. 29-37 & & & 40 \\
\hline
\end{tabular}


,

\section{•}




\section{University of Toronto Library \\ DO NOT REMOVE THE GARD FROM THIS POCKET Acme Library Card Pocket Uader Pat "Ref. Index File" Made by LIBRARY BUREAU}


